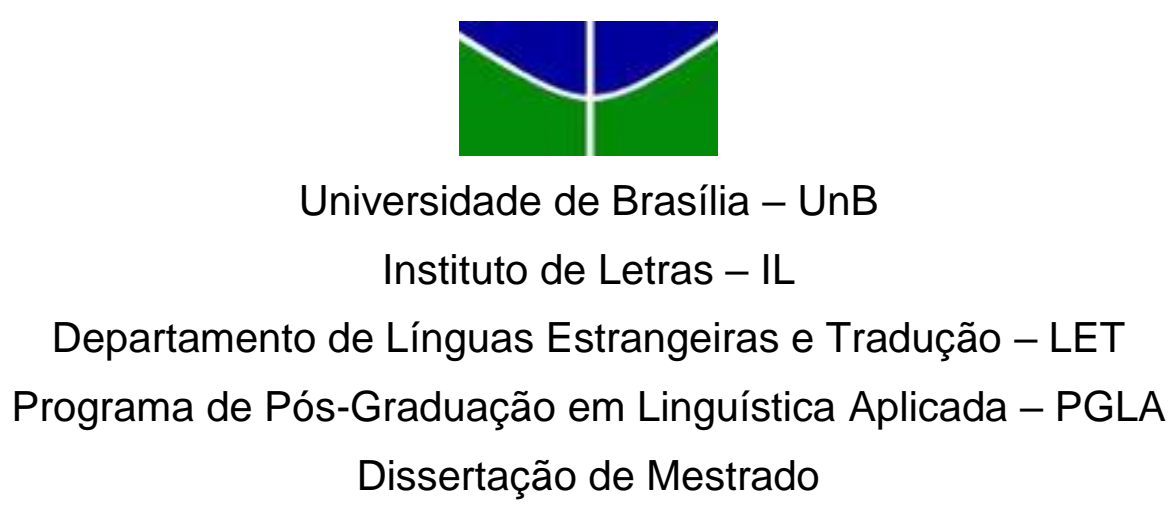

A REPRESENTAÇÃO DA CULTURA BRASILEIRA EM MATERIAL DIDÁTICO (INGLÊS) - DESTINADO A ADOLESCENTES

ANA CAROLINA BORGES CALIL

BRASÍLIA

2016 
ANA CAROLINA BORGES CALIL

\section{A REPRESENTAÇÃO DA CULTURA BRASILEIRA EM MATERIAL DIDÁTICO - (INGLÊS) - DESTINADO A ADOLESCENTES}

Dissertação apresentada ao Programa de PósGraduação em Linguística Aplicada da Universidade de Brasília, como requisito parcial para a obtenção do título de Mestre em Linguística Aplicada.

Orientadora: Pra. Dra. Lúcia Maria de Assunção Barbosa.

BRASÍLIA 


$$
\begin{gathered}
\text { Universidade de Brasília - UnB } \\
\text { Instituto de Letras - IL } \\
\text { Departamento de Línguas Estrangeiras e Tradução - LET } \\
\text { Programa de Pós-Graduação em Linguística Aplicada - PGLA }
\end{gathered}
$$

ANA CAROLINA BORGES CALIL

\section{A REPRESENTAÇÃO DA CULTURA BRASILEIRA EM MATERIAL DIDÁTICO - (INGLÊS) - DESTINADO A ADOLESCENTES}

Dissertação apresentada ao Programa de Pós-Graduação em Linguística Aplicada da Universidade de Brasília, como requisito parcial para a obtenção do título de Mestre em Linguística Aplicada.

Banca Examinadora:

Profa. Dra. Lúcia Maria de Assunção Barbosa - Orientadora Instituto de Letras - LET/UnB

Profa. Dra. Maria Del Carmen de la Torre Aranda - Membro Interno Instituto de Letras - LET/UnB

Prof. Dr. Francisco José Quaresma de Figueiredo - Membro Externo UFG

Profa. Dra. Mariana Mastrella-de-Andrade - Suplente Instituto de Letras - LET/UnB

Aprovado em: de de 2016. 
Ao meu marido e minha mãe pelo apoio incondicional, pois acreditaram, quando eu mesma não acreditei. 


\section{AGRADECIMENTOS}

À minha mãe que me exigia notas altas no inglês para que eu pudesse dançar ballet.

À tia Euripa, encantadora de crianças, minha professora do primário, de quem tive o privilégio de ser estagiária.

À tia Sandra, minha primeira professora de inglês; que me desafiava quando via em mim o potencial que minhas preocupações adolescentes negavam-se a ver.

À Matildes, que acreditou em mim e me empregou formalmente como professora aos dezessete anos de idade.

Aos amigos e colegas do Colégio Nossa Senhora das Dores, colégio onde estudei e trabalhei com grandes mestres.

À Cida que me trouxe a Brasília para buscar novos caminhos.

Aos amigos e colegas da Casa Thomas Jefferson, minha primeira casa em Brasília.

Ao amigo Murilo, conselheiro de gramática e fonologia.

À amiga Inez, que do alto continuará me inspirando.

Aos amigos e colegas do colégio Seriös, pelos desafios e pela confiança.

À minha orientadora, professora Lúcia, pelos ensinamentos e pela resiliência.

Ao meu marido, companheiro, revisor de texto, razão maior de eu ter chegado até o fim. As lágrimas e os sorrisos serão sempre seus. 
E, novamente, somos livres para negar a liberdade ou para exercê-la. Para lamber a bota sobre o pescoço ou para tentar sair de baixo. Para beber acriticamente de nossa cultura ou para olharmos criticamente para nós mesmos, para o mundo em que vivemos, metonimicamente representado em seus estereótipos, e pensar no mundo em que gostaríamos de viver. Somos presa da nossa sociedade, mas também seu potencial de mudança. Interagimos com o mundo, a cada ação nossa, e temos poder transformador, mesmo se restrito. Resta-nos exercer nossa liberdade e decidir se usamos tal poder ou se nos deixamos usar

E. Harkot-De-La-Taille 


\section{RESUMO}

O presente trabalho visa identificar a forma como a cultura brasileira é representada em uma coleção de livros didáticos de inglês para adolescentes. Através de levantamento bibliográfico e da análise da coleção de livros Time Zones, publicada pela Cengage Larning, pretendo evidenciar que, ao negligenciar os aspectos do ambiente sociocultural no qual os estudantes estão inseridos, os materiais didáticos interferem no processo de comunicação e limitam as interações a diálogos que são, muitas vezes, artificiais e vazios de significado. Este estudo de caso interpretativista feito através da análise documental dos quatro volumes que compõem a coleção Time Zones usa o suporte de teóricos como: Almeida Filho (2011, 2012, 2013); Baladeli (In: FERREIRA, 2014); Brown (2007); Crystal (1997); Hall (2003); Phillipson (1992). Nessa análise, verifquei que, na tentativa de atender o mercado global, os livros apresentam uma cultura neutralizada que não retrata fielmente nenhum dos povos ora mencionados. O livro multicultural, que deveria dar poder à cultura particular de cada indivíduo, tornou-se um desfile de estereótipos e um amálgama de velhos clichês. Por essa razão, em um espectro maior, espero que o presente trabalho gere discussões acerca da forma como a cultura e a sociedade brasileira têm sido representadas nos materiais didáticos de língua inglesa, e que tais discussões possam servir de ponto de partida para se pensar em materiais didáticos coerentes com as necessidades reais de comunicação dos adolescentes e que incentivem a formação e preparação de cidadãos críticos preparados para assumir papéis de liderança em um mundo de fronteiras cada vez mais tênues.

Palavras-chave: Cultura brasileira. Materiais didáticos. Adolescentes. Representação. 


\section{ABSTRACT}

The present work aims at identifying the way in which the Brazilian culture is represented in an English coursebook collection for teenagers. Through bibliographic research and the analysis of the Time Zones book collection, published by Cengage Learning, I intend to highlight the fact that, by neglecting aspects related to the sociocultural environment that the students live in, coursebooks interfere with the process of communication and limit the interactions to dialogues that are, quite often, artificial and meaningless. This interpretative case study done through the analysis of the four volumes that integrate the Time Zones collection is supported by theorists such as: Almeida Filho (2011, 2012, 2013); Baladeli (In: FERREIRA, 2014); Brown (2007); Crystal (1997); Hall (2003); Phillipson (1992). In this study I verified that, in order to cater for the global market, coursebooks bring neutralized cultures that don't represent any of its characters. The multicultural book, which should, in theory, empower the culture of each individual, has become a parade of stereotypes that sediment old clichés. For this reason, I hope that this research generates discussions that may be used as a starting point to think about coursebooks that are coherent with the real communication needs of teenagers and help form and prepare critical citizens who are ready to take on leadership roles in a world in which borders have become rather tenuous.

Keywords: Brazilian culture. Coursebooks. Teenagers. Representation. 


\section{LISTA DE FIGURAS}

Figura 1 - Trajetória dos livros didáticos de língua inglesa no Brasil............. 50

Figura 2 - Quadro comum europeu de referência para línguas..................... 72

Figura 3 - Página de apresentação......................................................... 73

Figura 4 - Caracterização da personagem................................................ 74

Figura 5 - Real English................................................................ 76

Figura 6 - Ilustração do texto............................................................. 78

Figura 7 - Globo terrestre ................................................................... 79

Figura 8 - Texto sobre o carnaval............................................................. 81

Figura 9 - Compreensão de texto......................................................... 82

Figura 10 - Exercício de produção........................................................... 83

Figura 11 - Redação: carnaval na Bolívia.................................................... 84

Figura 12 - Real World: Ano Novo....................................................... 89

Figura 13 - Ilustração sobre a capoeira...................................................... 92

Figura 14 - Texto sobre a capoeira........................................................ 93

Figura 15 - Compreensão de texto: capoeira................................................ 96

Figura 16 - Exercício: capoeira ............................................................ 96

Figura 17 - Ilustração sobre a Amazônia...................................................... 100

Figura 18 - Texto sobre a Amazônia........................................................... 101

Figura 19 - Compreensão de texto: Amazônia............................................... 102 


\section{LISTA DE ABREVIATURAS E SIGLAS}

ECA - Estatuto da Criança e do Adolescente

EFL - Inglês como Língua Estrangeira - English as a Foreign Language

ELT - Ensino de Língua Inglesa - English Language Teaching

ESL - Inglês como Segunda Língua - English as a Second Language

L2 - Segunda Língua

LD - Livro Didático

LDB - Lei de Diretrizes e Bases

LE - Língua Estrangeira

LEM - Língua Estrangeira Moderna

MD - Material Didático 


\section{SUMÁRIO}

1. INTRODUÇÃO

1.1. TEMA, RELEVÂNCIA E MOTIVAÇÃO DA PESQUISA .............................................12

1.2. OBJETIVO GERAL DA PESQUISA ............................................................... 15

1.3. OBJETIVOS ESPECÍfICOS ........................................................................15

1.4. MetodologiA ............................................................................................ 16

1.5. ESTRUTURA DA DISSERTAÇÃO .....................................................................17

2. REFERENCIAL TEÓRICO............................................................................19

2.1. ENSINO DE INGLÊS COMO LÍNGUA ESTRANGEIRA - EFL ....................................19

2.1.1. Aquisição de Língua Estrangeira..................................................... 19

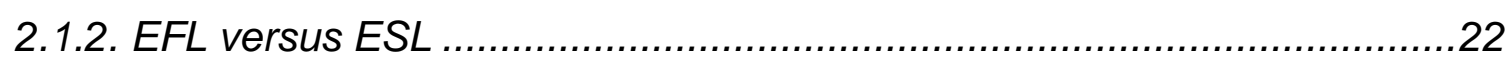

2.1.3. Inglês global ........................................................................ 24

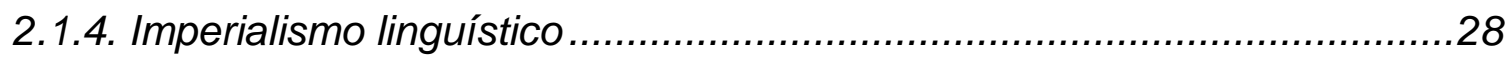

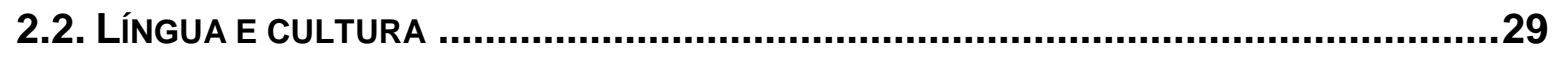

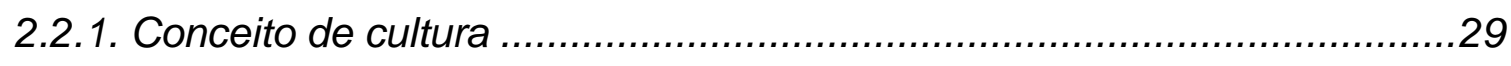

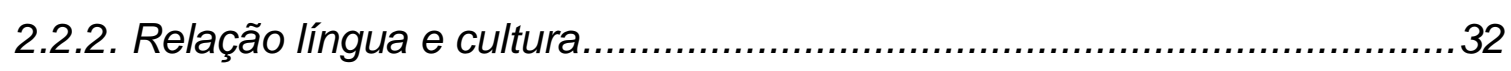

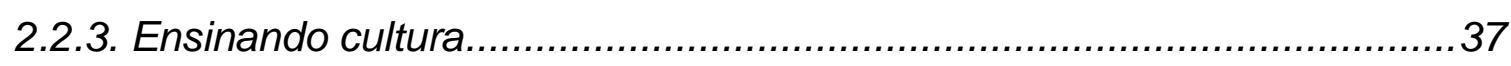

2.3. MATERIAL DidÁtico de LíngUa ESTRANGEIRA.............................................42

2.3.1. Material didático para adolescente.................................................. 43

2.3.2. O professor e o material didático..................................................51

2.4. REPRESENTAÇÃo CULTURAL EM MATERIAIS DIDÁTICOS DE LíNGUA ESTRANGEIRA . 55

2.4.1. Crenças e cultura do autor e sua influência sobre o material didático .....55

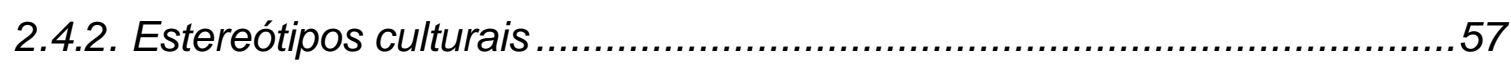

3. REFERENCIAL METODOLÓGICO ........................................................62

3.1. INTRODUÇÃO......................................................................................62

3.2. NATUREZA DA PESQUISA.............................................................................63

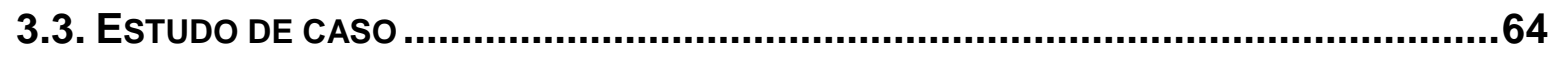

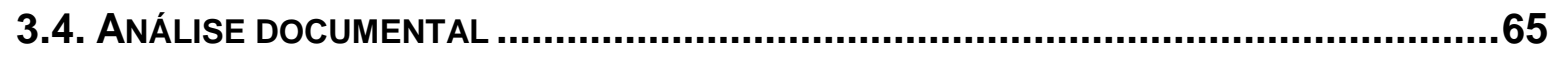

4. APRESENTAÇÃO E ANÁLISE DE DADOS ..............................................68

CONSIDERAÇÕES FINAIS .............................................................................101

REFERÊNCIAS..........................................................................................106 


\section{INTRODUÇÃO}

\subsection{Tema, relevância e motivação da pesquisa}

A sala de aula de língua é um ambiente de convergência de culturas, nela se encontram as crenças, costumes e práticas do professor, dos alunos e do autor/editor do material de didático. Isso posto, para que o processo de ensino/aprendizagem de línguas se dê de maneira fluida e de modo que se possa evitar conflitos, deve-se analisar de maneira crítica o papel das identidades socioculturais dos agentes envolvidos neste processo.

Cada um desses agentes de ensino-aprendizagem traz para a sala de aula não só a sua identidade, mas a percepção do papel cultural a ser desempenhado pelo outro. A sala de aula é um lugar no qual percebemos a cultura e a identidade do outro a partir da nossa própria visão de cultura. Assim, livros didáticos carregam ideologias e representações pautadas na cultura do autor ou do editor; professores trazem consigo a carga cultural de seu local de origem; e aos alunos, por sua vez, recai o papel de encontrar um papel que o represente de modo que ele se sinta inserido no contexto da língua ensinada em um ambiente escolar permeado por tantas culturas.

Ao longo de dezessete anos de sala de aula, em escolas regulares da rede particular de ensino e em cursos livres de língua inglesa, as representações culturais no livro didático de língua inglesa me trazem inquietação. A cada lançamento, na tentativa de atingir novos mercados consumidores, as editoras lançam mão de produções que apresentam a cultura de forma cada vez mais reducionista e generalizada. Foi dessa inquietação que nasceu a presente pesquisa, que tem por objetivo problematizar a forma com que a cultura brasileira tem sido representada na sala de aula de língua inglesa para que possamos pensar criticamente sobre o papel do professor enquanto mediador cultural e do aluno enquanto protagonista de sua aprendizagem de língua estrangeira. 
Em consonância com o que Almeida Filho discute em seus trabalhos, podese inferir que ensinar uma língua envolve muito mais do que ensinar sobre a língua, é um processo ativo cujo resultado esperado inclui, não somente, mas principalmente, a utilização da linguagem por quem a aprende para a comunicação e produção de significado. Sob a ótica da Abordagem Comunicativa, essa produção de significado se dá por meio da interação entre os falantes participantes de um determinado ato de comunicação e da negociação de sentidos entre eles. Segundo Almeida Filho (2013, p. 25), aprender uma nova língua

implica entrar em relações com outros numa busca de experiências profundas, válidas, pessoalmente relevantes, capacitadoras de novas compreensões e mobilizadoras para ações subsequentes. Aprender LE [língua estrangeira] assim é crescer numa matriz de relações interativas na língua-alvo que gradualmente se desestrangeiriza para quem a aprende.

Assim, ao falarmos de interações significativas entre indivíduos, não podemos deixar de falar da cultura desse indivíduo, haja vista que

a cultura reside nas pessoas, nos indivíduos. Cada membro de uma cultura, como um pequeno giro em um caleidoscópio, refrate e reflete as luzes coloridas comuns de suas culturas de uma forma única, reconhecidamente semelhante, ainda que inquestionavelmente diferente (MORAN, 2001, p. 98) (tradução nossa ${ }^{1}$ ).

Johnson (1995, passim) pontua que se os professores quiserem promover a comunicação em sala de aula, eles devem estar cientes de suas próprias suposições culturais, assim como serem capazes de entender o ambiente doméstico de seus alunos, estejam eles inseridos em ambientes de inglês como segunda língua (ESL), ou de inglês como língua estrangeira (EFL); se os dois pontos de vista - dos professores e dos alunos - não estiverem alinhados, abre-se margem para o surgimento de conflitos.

Quando falo de conflito em sala de aula, me refiro a qualquer atrito que possa surgir dentro da sala de aula em decorrência dos papéis culturais desempenhados por alunos, professores e livros didáticos. Quando o aluno não vê a possibilidade de ocupar o papel cultural do adolescente representado em seu livro ou sua cultura é trazida para a sala de aula como uma manifestação de menor

1 Todas as citações em língua inglesa utilizadas neste trabalho foram traduzidas pela autora. Portanto, para que a leitura fique mais fluida, deixarei de utilizar, deste ponto em diante, a expressão "tradução nossa". 
prestígio na sociedade, cria-se uma hierarquia. Ao estabelecer essa hierarquia, o professor pode estar negando ao aluno a chance de sentir parte de uma comunidade linguística, o que pode levá-lo a ter resistência a aprender a língua-alvo.

A sala de aula deve ser um ambiente de convergência de culturas e não de distanciamento, visto que a percepção que os alunos têm dos padrões de comunicação em sala de aula e de seu papel em eventos de sala de aula estão relacionados à maneira com a qual eles percebem e respondem ao que os professores dizem e fazem. Os professores, por sua vez, trazem para a sala de aula não somente as suas percepções de língua e cultura, mas também as percepções e crenças das editoras e autores dos materiais didáticos adotados. Ao adotar um material, o professor passa a subscrever às crenças deste livro e desempenha 0 papel de porta voz da cultura estrangeira. A influência que o material didático exerce nos fazeres diários do professor, conforme observa Almeida Filho (2012, p. 59-60):

\footnotetext{
As escolas privadas (regulares e de idiomas) e os grandes centros binacionais vendem um método de ensino geral que é, via de regra, condicionado pelo MD [material didático] comprado. E quando se compra um MD pronto para o uso, compra-se junto uma filosofia de ensinar que tem marca indelével no processo de ensino e até certo ponto no de aquisição ou aprendizagem que fica por conta do aluno.
}

Aquele autor complementa dizendo que, mesmo que se façam ajustes menores na prática diária de sala de aula, dificilmente se escapa da abordagem proposta pelos autores de um material didático. Do mesmo modo que o material representa uma dada abordagem, ele também "inevitavelmente expõe os alunos a uma representação do mundo que é manifestada através de seus textos, atividades e ilustrações" (TOMLINSON; MASUHARA In: PEREIRA; GOTTHEIM, 2013, p. 40)

A produção de material didático, como mostrarei neste estudo, é de grande interesse comercial, e recebe vultosos investimentos por parte das grandes editoras estrangeiras. Produzir material prêt-à-porter, feito sob medida de acordo com as necessidades individuais de cada grupo de aprendizes de língua, é dispendioso, leva tempo, e o resultado final, dificilmente será de um livro que consiga competir graficamente com aqueles produzidos por grandes nomes do mercado editorial. As coleções de hoje incluem áudio, vídeo, plataformas virtuais, ferramentas digitais interativas, e todo um acervo de atividades complementares que são inegavelmente atraentes para professores e alunos. Assim, ao se ver na impossibilidade de produzir 
conteúdo que possa competir com tais materiais, o professor de línguas fica refém das filosofias de ensinar impostas pelo material didático adotado.

Proponho, então, através do presente trabalho, dar voz à cultura do aluno de língua estrangeira. Não sou a primeira a fazê-lo, considerando-se que autores por mim citados no corpo dessa análise retrataram cultura, idade, gênero e classe social no livro didático. O fato é que, a falta de representação cultural do aluno não é um fator isolado e a mim, enquanto educadora, cabe, não esgotar o tema, mas engrossar o coro daqueles que não se veem figurados no livro didático, a fim de problematizar uma realidade tida como natural na sala de aula de língua estrangeira.

\subsection{Objetivo geral da pesquisa}

Este trabalho busca problematizar a forma com que a cultura brasileira tem sido representada na sala de aula de língua inglesa para que possamos pensar criticamente sobre o papel do professor enquanto mediador cultural e do aluno enquanto protagonista de sua aprendizagem de língua estrangeira.

Para que isso seja possível, proponho as seguintes perguntas de pesquisa:

a) De que forma as representações culturais trazidas pelo livro didático de língua inglesa podem impactar a sala de aula?

b) Como a cultura do adolescente brasileiro é apresentada no livro didático analisado?

\subsection{Objetivos específicos}

1) Discutir como as questões de representação e identidade afetam as relações em sala de aula e a aquisição de língua;

2) Problematizar a neutralidade cultural presente nos livros didáticos de alcance mundial;

3) Analisar como a cultura brasileira é apresentada nos quatro volumes do livro Time Zones, e se tal apresentação é precisa e legitima;

4) Debater, em especial, a personagem Maya enquanto representação de uma adolescente brasileira. 


\subsection{Metodologia}

Adotei neste trabalho a pesquisa qualitativa, com método estudo de caso interpretativista feito através da avaliação dos quatro volumes que compõem a coleção de livros didáticos de inglês para adolescentes "Time Zones" da editora Cengage Learning, dos quais dois foram analisados. Faço uso da modalidade de pesquisa qualitativa, por entender a sala de aula como sendo um ambiente no qual professores e alunos interagem com o intuito de compartilhar experiências de língua e na língua com o propósito comum de promover a aquisição de um dado conteúdo. Essa visão da sala de aula está em consonância com o conceito de pesquisa qualitativa de Antônio Chizzotti (2006, p. 28). O autor descreve essa pesquisa como sendo aquela que envolve o convívio com pessoas. Segundo ele, essa modalidade de pesquisa extrai significado, ou seja, interpreta, os resultados da partilha advinda dessa interação social entre pessoas, o que faz dela uma área transdisciplinar das ciências humanas e sociais.

O que faz então com que essa pesquisa seja um estudo de caso? Segundo Freebody (2003, p. 81), "estudos de caso focam em uma ocorrência particular da experiência educacional e tenta obter respostas teóricas e profissionais a partir da completa documentação dessa ocorrência". É evidente que não seria possível documentar e analisar todas as instâncias nas quais se têm a representação de brasileiros no universo editorial de materiais para ensino de língua inglesa. Seriam necessários anos de pesquisa para se esgotar a análise de todas as publicações para adolescentes disponíveis no mercado. Assim, optei pela referida coleção por ser uma publicação relativamente recente (2010) da Cengage Learning, uma multinacional de educação com publicações voltadas para os mais diversos contextos de ensino-aprendizagem, que promete tratar o multiculturalismo. $\mathrm{O}$ que me chamou atenção nessa coleção, foi a escolha de adolescentes de cinco lugares diferentes como personagens principais a fim de representar a totalidade dos adolescentes do mundo. O material, comercializado na Austrália, Brasil, Japão, Coréia, México, Singapura, Espanha, Reino Unido e Estados Unidos, traz uma adolescente brasileira como um de seus personagens principais. Esta coleção marcou a primeira parceria da National Geographic com uma empresa de educação a fim de que seu vasto acervo documental fosse utilizado para o desenvolvimento de materiais didáticos para o ensino de língua inglesa. 


\subsection{Estrutura da Dissertação}

A fim de melhor desenvolver os tópicos abordados nesta pesquisa, estruturei os diversos temas em cinco capítulos: introdução, referencial teórico, referencial metodológico, apresentação, análise de dados e considerações finais.

No primeiro capítulo, faço uma introdução que apresenta o tema por mim escolhido, bem como a motivação por trás da mesma. Em seguida, apresento os objetivos geral e específicos, bem como a metodologia empregada para que os mesmos fossem alcançados.

A delimitação do tema e dos objetivos permitiu que fizesse as leituras que integram o segundo capítulo, o referencial teórico. Neste capítulo, trabalhei assuntos como a aquisição de língua estrangeira e a abordagem mais aceita na atualidade; oposição entre inglês como segunda língua e inglês como língua estrangeira, assim como as implicações dos dois ambientes para os estudantes de uma segunda língua. Abordarei também os fatores que levaram o inglês ao status de língua global e as consequências que isso traz para as outras línguas. Nessa mesma tônica, discuto o imperialismo linguístico, e os seus efeitos no mercado editorial através da produção em larga escala de materiais didáticos voltados para o ensino da língua inglesa. Passando para a função que a cultura exerce na caracterização de uma sociedade, discorro sobre a relação entre língua e cultura, falando um pouco sobre o ensino de cultura, e a inserção da cultura na sala de aula. Por se tratar de uma análise documental, cujo documento é o material didático, abordo também os aspectos que regem o material didático de língua estrangeira, mais especificamente, o livro didático. Em seguida, trago a relação entre o professor e o material didático, retratando a influência indelével do segundo sobre o primeiro. Para finalizar o referencial teórico, levanto questões relativas à presença de estereótipos culturais tanto no material didático de língua estrangeira, como na sala de aula. Estereótipos esses muitas vezes trazidos pelos próprios professores e alunos, uma vez que eles trazem para a aula suas próprias visões de mundo e de cultura.

No terceiro capítulo faço um detalhamento da metodologia de pesquisa e aprofundo a natureza da pesquisa, bem como as modalidades estudo de caso e análise documental. Trago aqui as características desse estudo de caso qualitativo e descrevo as técnicas que viabilizam as análises por mim realizadas. Justifico aqui a escolha do material analisado, trazendo teóricos que dão suporte a essas decisões. 
As modalidades aqui descritas permitiram que o quarto capítulo, apresentação e análise de dados fosse escrito.

No quarto capítulo, faço um levantamento das instâncias nas quais a personagem brasileira, o Brasil e sua cultura são representados no material didático em questão. Aqui faço uma análise detalhada de cada texto ou imagem e os relaciono com a teoria apresentada no segundo capítulo. Mostro nesse capítulo, as interações de Maya com seus colegas, pois, apesar de a personagem figurar entre os personagens principais que compõem o enredo do livro Time Zones, muitas de suas interações são neutras e poderiam ter ocorrido com qualquer outro personagem. É nesse capítulo que busco me distanciar de Maya enquanto brasileira, para buscar analisar o seu papel enquanto embaixadora da cultura brasileira para outros adolescentes ao redor do mundo. O faço na tentativa de problematizar a representatividade neutralizada da cultura, um tópico trabalhado em outros estudos que analisam as identidades de classe, de gênero e de raça presentes no livro didático.

Finalmente, no quinto capítulo, teço as últimas considerações acerca das análises realizadas. Faço aqui considerações que dialogam com outros estudos do gênero e busco contribuir para que tais discussões não sejam deixadas de fora da sala de aula de língua estrangeira. Neste capítulo, mostro também as limitações da pesquisa, haja vista o tamanho da amostra, o tempo reduzido de estudo e as limitações de se fazer uma análise de cultura em um país de território tão vasto, permeado por tantos eu-culturais. Não posso deixar de considerar como limitação, a própria cultura e visão de mundo da pesquisadora, brasileira, mineira, branca, professora de escolas particulares que atendem à classe A. Deixo aberto, então, espaço para que novas discussões sejam levantadas no tocante à necessidade de se levar a cultura para a sala de aula e o papel do professor de línguas enquanto formador de cidadãos críticos e multiculturais. Longe de ser um trabalho acabado, considero este o começo de um diálogo a respeito do que vivo diariamente, após dezessete anos em sala de aula. 


\section{REFERENCIAL TEÓRICO}

\subsection{Ensino de Inglês como Língua Estrangeira - EFL}

No capítulo a seguir, faço considerações acerca do ensino de inglês como língua estrangeira. Pontuo aqui como se dá a aquisição de línguas e as diferenças de se adquirir uma primeira e uma segunda língua, bem como as diferenças de se adquirir uma segunda língua no ambiente em que ela é falada e em uma sala de aula como língua estrangeira. Brevemente discorro acerca dos fatores que deram à língua inglesa o status de língua franca, ou língua global, e as consequências que isso pode trazer para as demais línguas e culturas.

\subsubsection{Aquisição de Língua Estrangeira}

O estudo de aquisição vem marcado por hipóteses, teorias, discussões. Longe de ser uma ciência exata, as colocações feitas desde Stephen Krashen (1982) foram sendo comprovadas ou desqualificadas ao longo dos anos nas salas de aula de língua estrangeira mundo afora. Aquele autor complementa que os dados sobre aquisição são experimentais, pois as hipóteses podem surgir de maneiras variadas. Deste modo, o que valida uma hipótese é o teste de sua sobrevida no campo prático: se uma hipótese se confirma, ela sobrevive; se ela não se prova verdadeira mais adiante, ela deve ser reformulada. Assim, entre erros e acertos, no caso de Krashen, mais acertos que erros, considerando-se que poucas teorias foram alteradas ao longo dos anos desde sua primeira publicação em 1982, construímos os saberes acerca da aquisição de língua que usamos nos dias de hoje.

Primeiramente, é necessário fazer a distinção entre aquisição e aprendizagem. Segundo Krashen (1982, p. 10), a aquisição é "um processo semelhante, senão idêntico, à forma com a qual as crianças desenvolvem habilidades na primeira língua". Trata-se de um processo natural, muitas vezes subconsciente. Não existe aqui uma percepção de que o processo está em 
desenvolvimento, por essa razão, ele se dá de maneira não monitorada por parte do adquiridor de uma segunda língua. As regras são internalizadas sem que haja consciência da aplicação das mesmas, tendo-se a sensação de a gramática e os sons estarem ou "parecerem" ou não corretos. Trata-se de um processo quase que instintivo. A aprendizagem, por sua vez, passa a ser definido pelo "conhecimento consciente de uma segunda língua, conhecimento das regras, consciência das regras, ser capaz de falar sobre as regras" (KRASHEN, 1982, p. 10). Seria esse o processo de se estudar formalmente uma língua, de monitorar o seu uso de acordo com um conjunto de regras gramaticais.

A partir dessas definições, surgem então hipóteses acerca da ocorrência de tais fenômenos. A aquisição passa a ser o processo desejado na sala de língua, chegando-se a cogitar a distinção entre os dois processos em crianças e adultos. Krashen (1982) postula que adultos, apesar de nem sempre atingirem o mesmo nível de fluência que as crianças, podem sim, adquirir uma língua de forma natural. Autores como Nunan (1999), por exemplo, discutem os efeitos que a idade pode ter na aprendizagem de línguas e reforça o fato de que a idade pode influenciar na velocidade de aquisição ou na ordem na qual as estruturas são adquiridas, mas não configuram como fator impeditivo para o processo de aquisição como colocam os defensores da hipótese do "período crítico".

Lightbown e Spada (2013, p. 22) descrevem o período crítico como sendo "a hipótese de que animais, incluindo humanos, são geneticamente programados para adquirir certos tipos de conhecimento e habilidades em momentos específicos da vida". Após esse período "natural", o desenvolvimento dessas habilidades ficaria comprometido. As autoras reforçam as limitações em se comprovar essa teoria, uma vez que as crianças são expostas a alguma forma de linguagem desde a mais tenra idade. Mesmo em casos excepcionais nos quais as crianças tenham sido totalmente privadas de contato com uma língua, não é possível concluir que o atraso na aquisição tardia da língua tenha se dado somente pela idade, ou por traumas psicológicos advindos das situações adversas às quais essas crianças foram submetidas. São igualmente notórios os diversos casos de aquisição bem sucedida de uma segunda língua por adultos e o número desses casos é cada vez maior seja nas salas de aula de inglês como segunda língua, seja nas turmas de inglês como língua estrangeira. A plasticidade do cérebro vem sempre ao auxílio dos professores 
para provar que quando se trata da aquisição de língua, a maior certeza ainda é a de que quase tudo é possível.

Para fins deste trabalho, considerarei a visão mais ampla de que a aquisição é possível independentemente da idade e que a habilidade de se comunicar em mais de uma língua pode ser desenvolvida contanto que haja empenho e motivação para que isso aconteça. Adotarei, então, deste ponto em diante, o conceito de aquisição adotado na abordagem comunicativa. Adquirir uma língua estrangeira, na abordagem comunicativa, consiste em se apropriar do idioma e utilizá-lo em contextos onde haja comunicação significativa. Esse conceito se aproxima do conceito de aquisição de Krashen, e se distancia da ideia de aprendizagem como atividade mecânica de estudo das regras da língua. Com a abordagem comunicativa, a era das abordagens gramatizadas e engessadas, que preconizavam a repetição mecânica de modelos pré-estabelecidos, cedeu espaço a uma aplicação prática da língua em contextos naturais. A esse respeito, Almeida Filho (2011, p. 52) assevera:

A aquisição propicia, com o tempo, fluência e é duradoura. Ela opera em tempo e vida reais com naturalidade, sem pensar no processo adquiridor a cada passo, como se fosse uma segunda natureza na segunda língua sendo desenvolvida.

Segundo Almeida Filho (2011), as chances de se adquirir uma língua aumentam à medida que $o$ aprendente ${ }^{2}$ interage para comunicar-se na língua, o que a torna viva, criadora e cultural. A interação passa a ser o cerne da aprendizagem de línguas, pois ela promove a aquisição.

Convido então, o leitor, à análise de outro aspecto inerente à língua: a cultura. Considerando a língua como uma ferramenta carregada de cultura, é natural que certos aspectos culturais sejam transmitidos no processo de aquisição/aprendizagem de uma língua estrangeira. As interações na língua-alvo, passam a ser ações impregnadas de cultura e fazeres culturais tanto por parte dos aprendizes, como por parte do professor mediador, como ainda por parte da cultura da língua estudada através do livro didático e de seu conteúdo. Sendo assim, língua

\footnotetext{
2 O autor faz a distinção de "aprendente" e "aprendiz", pois considera que o primeiro termo se refira a alguém que esteja constantemente exercendo o esforço de aprender, enquanto o segundo se refira a alguém que já aprendeu. Optamos pelo termo "aprendiz", com o sentido do dicionário Michaelis: aquele que aprende arte ou ofício; deixando o termo "aprendente" para as citações referentes ao professor Almeida Filho apenas.
} 
e cultura ocupam o mesmo lugar quando a língua é apresentada como ação social propositada, uma vez que ela permeia não só a linguagem verbalizada, mas também os gestos, entonação e comportamento. Assim como cada sujeito é invariavelmente movido por uma cultura, língua e cultura, como veremos nos capítulos seguintes, são essencialmente indissociáveis.

\subsubsection{EFL versus $E S L$}

No subcapítulo acima, menciono dois ambientes no qual se pode aprender uma língua, o que nos traz a duas grandes categorias: ESL (Inglês como segunda língua) e EFL (Inglês como língua estrangeira). Brown (2007) define ESL como a aprendizagem de inglês em uma cultura na qual o inglês é falado como língua nativa e EFL como a aprendizagem de inglês dentro do contexto da própria cultura do aluno. Na primeira modalidade, a imersão na língua e na cultura não são opcionais, aliás, as atividades cotidianas do aluno dependem do sucesso dessa imersão. $\mathrm{Na}$ segunda modalidade, as oportunidades imediatas de uso da língua dentro do ambiente daquela cultura são escassas, fazendo com que os momentos em sala de aula sejam imprescindíveis à aquisição tanto da língua, quanto da cultura. Cada encontro é precioso para o desenvolvimento da oralidade, pois as oportunidades de se usar a língua fora de sala de aula podem ser poucas ou inexistentes.

Em ESL, do mesmo modo que a imersão na cultura e a necessidade real de comunicação podem promover a integração do aluno e facilitar a aquisição, elas podem gerar atrito e desmotivar a aprendizagem. Um aluno que não se sinta à vontade para se expressar na língua, pode desenvolver uma resistência em usar a língua, o que pode interferir na sua aquisição. Outro ponto a ser levado em consideração, é a posição a partir da qual o aluno fala. Se, por exemplo, sua língua e cultura não gozam de prestígio social, ele participa das interações em uma posição que é, de início, hierarquicamente inferior.

Na visão de Nayar (1997, p. 22 In: BROWN, 2007, p. 205), para corroborar seu ponto de vista, a distinção gerada pela terminologia ESL/EFL vem sedimentar a ideia de que o falante nativo é detentor inquestionável não só da competência no uso e ensino da língua, mas também da maneira como se deve ditar a forma de se ensinar inglês. Reforçar o mito do falante nativo como padrão de falante e de 
professor é ignorar anos de pesquisa em linguística aplicada e retroceder na caminhada em busca de uma língua internacional.

O material selecionado para análise promete promover o caráter internacional da língua inglesa ao selecionar quatro personagens de diferentes cantos do mundo: Brasil, China, África do Sul e Suécia. Sabemos que o número de falantes não-nativos de inglês em muito excede o número de falantes nativos e que o inglês é a língua dos negócios e da ciência. O catálogo de línguas Ethnologue (LEWIS, M. et al, 2015) traz o registro de 55.600 .000 habitantes no Reino Unido e uma população total, para todos os países que tem inglês como primeira língua, de 335.491.748 habitantes. Em contrapartida temos 1.500 .000 falantes de inglês como segunda língua no Reino Unido e 505.000.000 falantes de inglês como segunda língua ao redor do mundo. A diferença expressiva entre o número de falantes nativos e não nativos mostra a importância da língua no cenário internacional.

No entanto, o que é relevante percebermos aqui é o fato de que, apesar dessa expansão da língua inglesa enquanto língua estrangeira, independentemente da modalidade de ensino, ESL ou EFL, pode-se notar que a prática continua a mesma. A cultura do livro didático ainda é representativa da classe alta, branca, anglofalante, enquanto as manifestações culturais do "outro" são apresentadas através de curiosidades. É a cultura exótica da brasileira, do chinês, do norueguês e do sul africano em oposição à cultura do falante nativo de inglês, embora ele não seja geograficamente situado nos Estados Unidos ou na Inglaterra.

Ao falarmos de um material didático, mais especificamente aqui do livro didático, para o ensino de inglês como língua estrangeira, ao invés de vermos a convergência de culturas, vemos a estratificação das manifestações culturais: a nossa cultura $x$ a cultura do outro. A cultura vigente $x$ a cultura exótica. Assim, inglês deixa de ser a língua estrangeira para ser a língua estranha da qual o aprendiz não faz parte. Essa atitude faz com que a interação e, consequentemente, a aquisição sejam afetadas. 


\subsubsection{Inglês global}

Menciono anteriormente o status de língua franca, ou língua global desfrutado pela língua inglesa. Afinal, o que seria uma língua global? Segundo Crystal (1997, p. 2), "uma língua alcança status global genuíno quando ela desempenha um papel especial que seja reconhecido em todos os países". De acordo com o autor, para que isso aconteça, uma língua, independentemente do número de falantes nativos, deve ocupar lugar especial dentro de uma dada comunidade, o que pode ser feito através da oficialização da mesma (por governos, instituições de ensino, transações comerciais), ou por ser ensinada como língua estrangeira.

A existência de uma língua global encurta distâncias e enfraquece barreiras comerciais entre as nações. Para os falantes nativos, sua língua recebe uma importância hierarquicamente superior às outras línguas, uma vez que eles detêm a vantagem de não ter que aprender uma nova língua para participar dessa nova comunidade internacional surgida em função da expansão do raio de alcance de sua língua-mãe. Aos falantes de outras línguas, a participação dessa nova comunidade internacional fica condicionada à aprendizagem da língua considerada padrão. O não domínio desse código linguístico traz como consequência a exclusão do grupo responsável pela tomada de decisões. Uma pesquisa científica, por exemplo, só chegará à comunidade internacional se for publicada em inglês; uma política de direitos humanos será, invariavelmente, discutida em inglês. A língua global, ao mesmo tempo em que une nações, fortalece barreiras e contribui para a extinção de dialetos menos falados ou de menor relevância no cenário político-econômico mundial.

No Brasil, a trajetória do ensino de línguas estrangeiras sofreu a influência de várias reformas educacionais que determinavam a língua a ser estudada, a carga horária e até mesmo o método a ser adotado. Nossas escolas ensinaram latim, grego, francês, inglês, alemão e italiano. Leffa (1999) faz um apanhado dessas mudanças que vai desde o império até o cenário atual. $O$ autor coloca que as línguas estrangeiras sempre ocuparam lugar de destaque em nossa educação. Um marco importante nesse percurso se deu com a Reforma Capanema, de 1942, que equiparava todas as modalidades do ensino médio: secundário, normal, militar, comercial, industrial e agrícola. 


\begin{abstract}
A Reforma Capanema, ainda que criticada por alguns educadores como um documento fascista pela sua exaltação do nacionalismo, foi, paradoxalmente, a reforma que deu mais importância ao ensino das línguas estrangeiras. Todos os alunos, desde o ginásio até o científico ou clássico, estudavam latim, francês, inglês e espanhol (LEFFA, 1999, p. 11).
\end{abstract}

Segundo o autor, os alunos saiam do ensino médio lendo autores clássicos dessas línguas. A essa reforma, no entanto, seguem as Leis de Diretrizes e Bases (LDBs) de 1961 e 1971, que acarretaram na redução da carga horária de língua estrangeira, com algumas escolas eliminando por completo a língua estrangeira do primeiro grau. Vinte e cinco anos mais tarde, a LDB de 1996 traz a estruturação do ensino fundamental e médio aos moldes que conhecemos hoje, e determina o ensino de uma língua estrangeira moderna como componente da parte diversificada do currículo. Língua essa a ser determinada pela comunidade de acordo com a disponibilidade da escola. Assim, hoje no Brasil, a língua inglesa, língua global, é parte integrante da grade curricular de Língua Estrangeira Moderna (LEM) dividindo carga horária, em algumas instituições, conforme disponibilidade, com a língua espanhola.

A opção pela língua inglesa nas escolas não acontece somente no Brasil. Crystal (1997, p. 5) justifica essa hegemonia da língua inglesa com a seguinte premissa: "A língua existe somente nos cérebros e bocas e ouvidos e mãos e olhos de seus usuários. Quando eles são bem sucedidos, no cenário internacional, sua língua é bem sucedida. Quando eles falham, sua língua falha".

De certa forma, o poder político, militar, econômico e tecnológico de um povo faz com que sua língua tenha grande alcance internacional. Esse grande alcance internacional faz com que o Brasil seja mais um, no rol de tantos outros países que optaram por fazer da língua inglesa uma língua global.

Crystal (1997, passim) cita ainda outros fatores que dão ao inglês o status de língua internacional hoje em dia: as relações internacionais, a mídia (propaganda, telecomunicações, imprensa, filmes, música), viagens internacionais, segurança internacional, educação. A esses fatores, acrescento ainda a expansão da rede mundial de computadores e o encurtamento das distâncias trazido pelas redes sociais. Araújo e Leffa (2016, p. 9) chamam as redes sociais de "fecundas" em possibilidades de pesquisa no que tange o aprender e o ensinar de um idioma estrangeiro. Em especial, achamos por bem frisar, o inglês - que é a língua originária das redes de alcance global e usada de maneira ampla mesmo entre os 
não-falantes da língua nesses ambientes virtuais. Vemos que tanto os fatores inequívocos apontados por Crystal duas décadas atrás quanto às interações novas oriundas do desenvolvimento tecnológico e da expansão e popularização da internet continuam contribuindo para a manutenção do inglês como a língua internacional.

A disseminação da língua inglesa como língua global não representa necessariamente uma ameaça às línguas nativas de cada país, no entanto, há de se pensar as relações sociais, históricas, culturais e políticas advindas dessa homogeneização linguística. Pennycook, 2007 (In: BURNS; COFFIN, 2007, p. 80) assim discute essas relações:

\footnotetext{
Há uma falha em se problematizar o conceito de escolha e uma presunção de que indivíduos e países são, de alguma maneira, livres de restrições econômicas, políticas e ideológicas; há uma falta de análise histórica que levantaria muitas outras questões sobre a suposta naturalidade da disseminação do inglês durante os períodos coloniais e não coloniais.
}

A discussão aqui levantada não tem como fim questionar o status da língua inglesa enquanto língua global, e sim levantar questionamentos sobre como esse status foi adquirido e de quão naturalmente aceitamos esse status. O mandarim, a despeito de seus um milhão e duzentos falantes, não desfruta do mesmo prestígio que o inglês. Apesar de ouvirmos que o mandarim será a língua do futuro, não vemos uma corrida das escolas no sentido de se prepararem para essa mudança. $O$ alfabeto ideográfico, ou ideogramático pode até ser uma barreira para essa expansão, no entanto sabemos que, para que uma língua se torne global, é preciso mais do que um grande número de falantes.

A naturalidade com a qual uma significativa parcela da sociedade aceita e reproduz o discurso de que a língua inglesa atingiu o status de língua global sem influência política e, consequentemente, sem consequências e implicações para a cultura dos países que não possuem o inglês como língua nativa é, no mínimo digna de questionamento. Phillipson (1992) demonstra essa preocupação ao dizer que a crença de que ELT (ensino de língua inglesa) é apolítico desvincula a estrutura da cultura e separa o ensino de língua inglesa de questões educacionais mais amplas. Deste modo, as demandas do mercado local são desconsideradas em favor da exportação da língua inglesa como um produto padrão. 
A comercialização da língua inglesa como produto industrializado padrão é altamente rentável para as editoras e distribuidoras de material, fator que não passa desapercebido entre os profissionais da área. As editoras produzem materiais em larga escala sem ao menos considerar as individualidades de cada mercado para o qual esse material será distribuído. Quanto mais efetivo for o "molde", maior será o seu alcance e, consequentemente, o lucro gerado por ele. Para o ensino, esse padrão de língua pré-moldada empobrece as relações de sala de aula e limita o conteúdo trazido para o aluno à cultura do livro didático, aumentando a lacuna entre a cultura do aluno e a "cultura do outro" representada em tal material. Phillipson (1992, p. 48-49) menciona a fala do diretor geral do British Council no Relatório Anual de 1987/1988:

O verdadeiro ouro negro não é o petróleo do Mar do Norte, mas a língua inglesa. Ela que há muito tem sido a raiz de nossa cultura está se tornando rapidamente a língua global dos negócios e da informação. Nosso desafio agora é explorá-la em sua totalidade.

Vemos, nessa fala, o representante de um órgão oficial, o Conselho Britânico, claramente preocupado em potencializar os ganhos oriundos da exploração da língua inglesa enquanto produto comercial. A materialização desse comércio é especialmente evidente quando se trata de materiais didáticos, aqui entendidos de forma mais ampla: vídeos, áudio, livros, dicionários, gramáticas e materiais de apoio em geral. Quanto mais neutro culturalmente for o material, maior será o número de países para os quais ele poderá ser distribuído, quanto mais personalizado, menor será esse alcance e menores os ganhos.

A expansão do inglês global é motivada política, econômica e ideologicamente. Esses aspectos fazem-se presentes quer 0 aprendiz esteja consciente deles ou não. Cabe a nós, educadores e multiplicadores culturais, garantirmos que nossos alunos receberão uma educação também global, que não negligencie os aspectos macro de nossa sociedade em prol de uma cultura fast food. Ou seja, não podemos fechar os olhos para o fato de que a cultura neutralizada, nacionalmente inespecífica: que não ofende e que não representa a ninguém, é simplesmente um artifício para que se possam vender mais livros a países cada vez mais diversos culturalmente. 


\subsubsection{Imperialismo linguístico}

No subcapítulo anterior, falei sobre a expansão da língua inglesa como língua global e mencionei a existência de intenções político-ideológicas por trás deste crescimento. Nesta seção, farei uma breve explanação sobre imperialismo linguístico, um assunto intimamente ligado às motivações existentes por trás da internacionalização da língua inglesa.

Phillipson (1992) afirma que o imperialismo da língua inglesa se dá quando reforçam-se as desigualdades culturais e estruturais entre ela e as demais línguas. A partir desta ideia, o termo "anglocentrismo" surge em analogia ao conceito de etnocentrismo. Este sendo definido como a "prática de julgar outras culturas a partir dos padrões da sua própria cultura" (PHILLIPSON, 1992, p. 47); logo, anglocentrismo trata-se de usar as culturas de matiz anglo-saxão, notoriamente a norte-americana, como padrão pelo qual todas as outras culturas são julgadas.

Aquele autor segue dizendo que, por ser um meio de transmissão de ideias, o imperialismo linguístico acaba por influenciar todos os tipos de imperialismo, inclusive o cultural, mesmo que a cultura seja expressa por outros meios além da língua (música, pintura, dentre outros). Phillipson (1992) cita também o imperialismo na tradução, que vai desde obras consideradas eruditas, ou de alta cultura, até desenhos animados da Disney que, apesar de serem traduzidos para dezoito línguas e terem sido lançados em quatro edições especiais em língua espanhola, trazem pouca ou nenhuma variação de conteúdo.

Corroborando com esta visão, Cook (1998 In: PENNYCOOK In: BURNS; COFFIN, 2007) descreve o inglês como um Cavalo de Tróia. Tal qual o mito registrado por Homero, a língua inglesa é apresentada como uma dádiva enquanto deixa obscuros os interesses de servir a uma classe específica. Pennycook menciona a si próprio e a Judd (1983), para destacar as implicações morais e políticas do ensino de inglês no mundo devido às ameaças desta prática para as línguas nativas e aos efeitos que isso traz para o mercado de trabalho ao impedir que pessoas não fluentes na nova língua consigam boas oportunidades de emprego. 
Seria difícil elencar as formas de imperialismo que surgem a partir do imperialismo linguístico, tampouco seria possível ranqueá-las de acordo com os possíveis danos que causam às demais culturas e sociedades. Acredito que haja um empobrecimento cultural quando se elege um modelo padrão de estrutura social, normas e comportamento em detrimento de quaisquer outros. A uniformização das culturas impede a disseminação de novas manifestações culturais e causa, até mesmo, o apagamento de algumas delas. Se, como defini antes, somos através da língua, quando adotamos uma língua que não a nossa como padrão, estamos abandonando a possibilidade de sermos e de nos expressarmos de maneira plena. Quando deixamos a nossa língua, a nossa sociedade e a nossa cultura de lado em favor do crescimento da língua do outro, fortalecemos o império e garantimos a hegemonia política e ideológica da corte.

\subsection{Língua e cultura}

Uma vez estabelecido o conceito de imperialismo linguístico, acredito ser necessário para a discussão que procuro desenvolver no presente trabalho abordar os conceitos de língua e cultura. Afinal, o que entendo por língua e cultura tornar-seá vocabulário necessário para a compreensão da análise que realizarei do material estudado. Primeiramente, procuro estabelecer um conceito de cultura, uma vez que cultura possui várias definições amplamente debatidas por diversos autores. Em seguida, busco mostrar a relação indissociável da língua e da cultura. Para finalizar o capítulo, abordo aspectos relativos ao ensino da cultura e o ao papel fundamental de se trazer a cultura para a sala de aula.

\subsubsection{Conceito de cultura}

Cultura é um conceito que não possui uma definição única. Há várias definições de cultura e vários contextos nos quais o termo é utilizado. Longe de esgotar o assunto, ou de propor um conceito único e acabado de cultura, farei um breve apanhado dos empregos mais comuns do termo e elegerei um deles para fins deste estudo. Moran (2001) fala sobre as dificuldades de se definir cultura e sobre as variadas respostas à pergunta: o que é cultura? De acordo com aquele autor, 
"cada definição fatia a torta cultural de uma maneira diferente" (MORAN, 2001, p. 23). Segundo ele, há cinco dimensões da cultura a serem levadas em consideração: produtos, ou artefatos de cultura; práticas, ou ações e interações dos membros de uma cultura; perspectivas, o que engloba as crenças e valores que guiam uma comunidade; comunidades, incluindo aqui os contextos sociais, circunstâncias e grupos que dão continuidade a certas práticas culturais; e pessoas, os membros individuais que incorporam a cultura. Para as análises desse estudo, precisarei valer-me de várias dessas dimensões e de combinações das mesmas. Tentarei, então, agrupar algumas das muitas definições de cultura por semelhança.

As definições a seguir remetem à coletividade, às práticas comuns de um grupo de pessoas dentro de uma sociedade. Brown (2007, p. 188), define cultura como sendo "um modo de vida. É o contexto no qual nós existimos, pensamos, sentimos e nos relacionamos com os outros. É a 'cola' que mantem um grupo de pessoas junto". O autor lança mão das semelhanças no fazer diário de uma comunidade. Nesse sentido, a cultura significa nosso modo de pensar e de agir. Reforçando essa ideia, Brown (2007, p. 188) oferece ainda outra definição: "Cultura é o nosso continente, nossa identidade coletiva".

Em consonância com Brown (2007), Kramish (1998, p. 10) descreve cultura como uma "membresia em uma comunidade discursiva que compartilha um espaço social e histórico comum e imaginários comuns." O autor acresce ao conceito de Brown, o fato de a cultura ser influenciada pela história, não sendo, portanto, estanque. As práticas tidas como culturalmente desejáveis por uma comunidade em um dado período da história, podem não sê-lo para a próxima geração dessa comunidade. As comunidades mudam suas características e práticas através das gerações, o que nos leva a estabelecer o caráter dinâmico da cultura.

Intimamente ligada ao comportamento humano, a cultura é, segundo Larson e Samalley (1972 apud BROWN, 2007), a 'planta baixa' do comportamento humano. Assim, podemos dizer que a cultura que nos leva a cumprimentar os amigos com aperto de mão ou com beijos no rosto. É a cultura que nos faz usar talheres ou comermos com as mãos. É a cultura que nos faz cobrir ou soltar os cabelos em público, interagir ou não com pessoas do sexo oposto. Todas as nossas interações cotidianas são culturalmente motivadas. A cultura está arraigada na vida em família. É ela que determina como os outros esperam que nos comportemos e nos dá a 
sensibilidade para entender como devemos agir e o que devemos fazer para satisfazer a essas expectativas.

Tomlinson e Masuhara (In: PEREIRA; GOTTHEIM, 2013) trazem as definições antropológica e sociológica de cultura. A primeira seria o conjunto de costumes, produções artísticas ou até mesmo a civilização de um país ou de um povo, como as culturas inca ou brasileira. A segunda compreenderia o modo de vida compartilhado por um grupo, incluindo seus valores, atitudes, atividades e crenças. Os autores colocam ainda uma terceira definição de cultura. Diferentemente das outras definições, que se referem ao grupo sem emitir juízo de valor, o conceito de cultura como refinamento intelectual e estético, geralmente usado no sentido de se "ter" ou "não se ter" cultura, de "ser" culto ou não, define uma elite como padrão desejável de comportamento e exclui o grupo que não pertence a essa elite.

Edward Hall (1976), em sua obra Beyond Culture, busca elucidar questões concernentes à cultura em seu sentido mais amplo. $O$ autor não descarta sistemas filosóficos, religião, organização social, língua, valores morais, arte e cultura material, no entanto, ele privilegia a maneira através da qual as coisas se relacionam ao invés das teorias isoladas. Assim, aquele autor coloca três características da cultura sobre as quais concordam os antropologistas: "ela não é inata, mas aprendida; as várias facetas da cultura são inter-relacionadas - você toca a cultura em um lugar e tudo mais é afetado; ela é compartilhada e, como efeito, define as barreiras de diferentes grupos" (HALL, 1976, p. 16). O autor segue dizendo que a cultura toca todos os aspectos da vida humana: modo de expressão, personalidade e tudo que envolve a organização de nossa sociedade.

Muitos dos conceitos de cultura descritos acima se interpolam, muitos deles discordando inclusive das mesmas coisas. Para fins deste estudo, adotarei o conceito mais amplo de cultura, aquele que se refere ao fazer coletivo, às práticas coletivas que diferem um grupo de pessoas dos demais. Deste modo, após considerar os autores supracitados, e incorrendo o risco de não o fazê-lo de maneira imparcial tampouco original, escrevo minha própria definição de cultura: cultura é o conjunto de características que norteiam as práticas de uma comunidade em um dado período da história. Com essa definição, tento estabelecer dois aspectos importantes da cultura: a coletividade e a mutabilidade da cultura. 


\title{
2.2.2. Relação língua e cultura
}

Vimos no subcapítulo anterior que uma comunidade cultural é caracterizada por um conjunto de práticas inerentes à sua vida em sociedade, práticas essas que são repetidas quase que de modo automático pelos membros do grupo. Considerando-se que as línguas são revestidas dessas práticas, ou seja, revestidas de cultura, ao adquirirmos uma segunda língua, adquirimos com ela uma nova cultura. Língua e cultura mantém uma relação de codependência e inseparabilidade, ilustrada por Brown (2007, p. 189) da seguinte maneira:

\begin{abstract}
Uma língua é parte de uma cultura, e uma cultura é parte de uma língua; os dois estão intricadamente entrelaçados de modo que não se possa separálos sem perder a significância da língua ou da cultura. A aquisição de uma segunda língua, excetuando-se a aquisição especializada, instrumental (como pode ser o caso da aquisição da habilidade de leitura de uma língua para a compreensão de textos científicos), é também a aquisição de uma segunda cultura.
\end{abstract}

Para o autor, a cultura, como conjunto de comportamentos e percepções, é de fundamental importância na aprendizagem de uma segunda língua. A menos que se esteja fazendo uso da modalidade ESP (inglês para fins específicos), ao adquirirmos uma língua, estamos automaticamente adquirindo traços culturais daquela língua. É comum aos brasileiros dizerem "Me dá uma água, por favor" ou "Eu quero uma água, por favor", culturalmente o uso do imperativo em uma situação informal ou mesmo em um restaurante seria absolutamente aceitável e não causaria estranhamento por parte do interlocutor. No entanto, se o imperativo for usado em um restaurante de um país anglofônico, o cliente pode ser percebido como rude, causando assim, ruídos na comunicação, o que pode afetar negativamente a qualidade da interação. Cada ato de fala é carregado de cultura, assim como as nossas ações também o são. O grau de formalidade, de polidez, de intimidade com que nos dirigimos aos outros é, por si só, um ato cultural.

Durante os anos que antecederam a abordagem comunicativa, era comum ouvir frases como: "Só se aprende uma língua se for morar no exterior", ou "É preciso abandonar a cultura do seu país e adotar para si a cultura do país falante da língua a ser estudada". Acreditava-se que para a aquisição de língua e cultura, era necessário desvincular-se de sua cultura para que se desse a imersão na cultura e língua do outro. Havia a "minha cultura" enquanto aluno e a "cultura do outro" 
representando as práticas e costumes da comunidade cuja língua está sendo estudada. Vejo dois problemas com essa concepção: o primeiro diz respeito à valorização de uma cultura em detrimento de outra; o segundo, diz respeito ao fato de não termos, no caso da língua inglesa, um único país de referência para essa cultura, o que faz com que o problema seja ainda maior.

Levando-se em consideração o grande número de países que tem a língua inglesa como língua oficial, seria no mínimo generalista falar em cultura da língua, pois imediatamente teríamos a cultura da Inglaterra, dos Estados Unidos, da Austrália, da África do Sul. Isso posto, temos ainda o surgimento de um outro impasse que nos remete à seção sobre imperialismo linguístico, pois, ao falarmos de "cultura inglesa", estamos automaticamente nos referindo à cultura dos países produtores de material didático para o ensino da língua inglesa. Sendo assim, é natural que o estudante de inglês não tenha como referência de "cultura inglesa" as práticas culturais da Austrália e da África do Sul, e sim dos Estados Unidos ou da Inglaterra. $\mathrm{O}$ que nos traz às questões concernentes à cultura e identidade.

Zacharias (2010), em consonância com os conceitos de identidade preconizados na pós-modernidade, desmitifica a crença de que se deve minimizar ou abandonar a identidade étnica da L1 (língua materna) e adotar os padrões do falante nativo para se ser bem sucedido na aprendizagem de línguas. A autora afirma que esta prática comum ignora o fato de que a cultura é parte integrante da identidade dos aprendizes e que, ao forçar que os aprendizes de língua estrangeira adotem para si os padrões do falante nativo, cria-se um conflito de identidades.

Se o inglês, língua franca do mundo, pertence ao povo que a fala (Jenkins, 2007; Norton, 1997), e não somente aos chamados falantes nativos, então faz-se necessário questionar até que ponto as metodologias e técnicas de sala de aula acomodam as identidades dinâmicas e multidimensionais dos aprendizes de EFL (inglês como língua estrangeira) (ZACHARIAS, 2010, p. 27).

Cabe aqui ressaltar novamente que o padrão do falante nativo, no caso da língua inglesa em especial, pode sofrer variações grandes conforme o país ao qual estamos nos referindo. Assim, as salas de aula não só devem acomodar as diversas identidades dos falantes nativos, como as identidades dos aprendizes de EFL. Essa discussão oferece uma alternativa à língua global pré-moldada. Temos aqui, 
alternativamente, um empoderamento do aprendiz enquanto usuário da nova língua, sem que com isso abandone sua própria identidade e sua própria cultura.

A possibilidade de se estabelecer novas identidades traz à luz a questão da referência e das diferenças, visto que só podemos perceber o outro sob a ótica de quem somos. Para que possamos entender quem é o outro, tomamos a nós mesmos como referência, pois vemos o outro a partir de nós mesmos. Do mesmo modo, as diferenças entre 'eu' e 'outro' determinam as posições de sujeito de cada um. Sendo assim, o outro é aquilo que eu não sou. Segundo Silva, Hall e Woodward (2000, p. 75-76), "a identidade é a referência, é o ponto original relativamente ao qual se define a diferença. Isto reflete a tendência a tomar aquilo que somos como sendo a norma pela qual descrevemos ou avaliamos aquilo que não somos".

A pós-modernidade permite o trânsito constante entre culturas. Isso se dá através do encurtamento das distâncias virtuais e reais propiciado pela rápida evolução dos meios de comunicação e transporte. Através desses meios, o acesso à informação foi facilitado e a interação entre pessoas de todos os pontos do globo passou a acontecer de maneira natural e espontânea. Essa fluidez acaba contribuindo para uma homogeneidade cultural que, segundo Silva, Hall e Woodward (2000, p. 21), pode tanto trazer consequências positivas quanto negativas:

\footnotetext{
A homogeneidade cultural promovida pelo mercado global pode levar ao distanciamento da identidade relativamente à comunidade e à cultura local. De forma alternativa, pode levar a uma resistência que pode fortalecer e reafirmar algumas identidades nacionais e locais ou levar ao surgimento de novas posições de identidade.
}

Neste sentido, ao mesmo tempo que a homogeneidade cultural distancia as pessoas de suas comunidades e culturas locais, ela pode gerar o efeito contrário quando permite o surgimento de novas posições de identidade. Ao transitarem de uma cultura para a outra, os sujeitos deixam marcas de sua cultura na cultura do outro. Esse intercâmbio de culturas vai pouco a pouco transformando a face das diversas culturas, fazendo com que surjam características comuns verificáveis em quase todas as culturas. A homogeneização das culturas pode, a princípio, dar a impressão de ser um processo de extinção da individualidade cultural, no entanto, pela própria natureza dinâmica das identidades, ela pode gerar o efeito contrário quando, ao incitar a resistência, reafirma identidades nacionais e locais. 
Percebo dois outros aspectos acerca da homogeneidade trazida pelo intercâmbio entre as culturas: o primeiro diz respeito à predominância das culturas de maior prestígio devido ao poder socioeconômico do país de origem e o segundo diz respeito a uma alternativa na qual as culturas possam conviver lado a lado sem que suas características essenciais sejam perdidas. Com a globalização e a expansão das multinacionais, vejo o crescimento da influência dos países de maior poder econômico, assim, a homogeneização tende a privilegiar as características e práticas culturais desses países. Por exemplo, apesar de termos hoje restaurantes indianos nas grandes cidades de vários países culturalmente distintos, e de sabermos que existe uma indústria cinematográfica na Índia, Bollywood, que produz inúmeros filmes por ano, o acesso a essa culinária vista como "exótica" e a esses filmes distribuídos em salas de cinema "de cultura" não são tão disseminados quanto o acesso à cultura do hambúrguer e dos filmes de Hollywood. Sob esse prisma, ainda que 0 trânsito entre culturas permita $\circ$ surgimento de uma terceira possibilidade, uma intercultura, por assim dizer, essa "nova" cultura homogeneizada ainda sofrerá influência dos países de maior poderio econômico.

Creio que a alternativa que renderia melhores resultados, no sentido de preservar e respeitar o caráter único que define e distingue uma cultura de outra, seria um modelo no qual as várias culturas pudessem conviver harmoniosamente. Sei que essa visão pode parecer utópica no sentido de que a própria curiosidade com relação à cultura do outro pode levar à troca e à experimentação o que, inevitavelmente, nos traz de volta à homogeneização. Assim, resta a nós, professores, conscientes de nossa impotência diante das interações ocorridas fora da sala de aula, garantirmos que a sala de aula seja um lugar de trânsito livre para toda e qualquer manifestação cultural, permitindo aos alunos experimentarem posições identitárias diversificadas.

Clancy (1986, p. 213 apud JOHNSON, 1995, p. 59), afirma que: "o modo como a língua é usada e compreendida em uma determinada cultura, tanto reflete como reforça crenças culturais fundamentais sobre o modo de ser de um povo e a natureza de sua comunicação interpessoal". Considerando-se que a comunicação interpessoal é regida pelo modo de ser de um povo, devemos, enquanto estudantes de língua, estar atentos para essas nuances culturais da comunicação para que não hajam estranhamentos culturais ou falhas na comunicação. Isso posto, devemos 
aprender a nos comunicar na língua e na cultura do outro sem que para isso seja necessário abandonar a nossa própria cultura. Segundo Fernández (2002, p. 41),

\begin{abstract}
não se deveria empregar uma língua estrangeira desconsiderando os valores sociais e culturais que a permeiam, mesmo que do ponto de vista linguístico exista correção. Inclusive, chega-se a afirmar que 'os erros culturais afetam a sensibilidade do interlocutor, enquanto os erros linguísticos costumam despertar a sua cooperação', isto é, existe certa predisposição por parte dos falantes nativos no sentido de realizar esforços para entender aquilo que um estrangeiro quer dizer, desde que o contexto sociocultural seja respeitado por ele.
\end{abstract}

Um falante gramaticalmente competente pode causar antipatia em seu interlocutor caso não respeite suas práticas culturais. No entanto, uma pessoa culturalmente fluente, ou seja, que conhece e aplica as amenidades sociais inerentes à cultura do outro, pode suscitar a cooperação do mesmo se cometer um erro gramatical. Não basta ser fluente em uma língua se a competência cultural não acompanhar a habilidade linguística.

\footnotetext{
Se considerarmos que 'aprender uma língua implica aprender a cultura na qual se desenvolveu e se desenvolve um número determinado de situações socioculturais que fazem com que um ato de fala seja como é e não de outra forma', devemos também considerar que certos comportamentos sociais implicam o uso de determinadas formas linguísticas, conhecidas e aceitas pela comunidade que emprega essa língua (FERNÁNDEZ, 2002, p. 40).
}

Um falante nativo de inglês relevaria o uso incorreto de um tempo verbal ou de uma preposição, se o interlocutor valer-se de expressões como "licença", "por favor", "obrigado". Para um falante nativo de português do Brasil, um pedido em um restaurante pode ser iniciado com as frases "me dê...", "me veja um...", ao passo que, em países anglofônicos, o uso do imperativo pode ser considerado ofensivo. Cumprimentar uma pessoa que acabou de conhecer com um, dois, ou até três beijos no rosto pode ser comum no Brasil, ao passo que em outros países essa prática pode conotar um excesso de intimidade e causar incômodo às pessoas.

Os atos de fala não são isentos de cultura. Ao valer-se de uma língua para se comunicar, deve-se ter em mente os scripts culturais que acompanham essa língua. Língua e cultura mantém uma ligação de co-dependência que deve ser trabalhada na sala de aula de língua estrangeira para que formemos bilíngues ou multilíngues culturais. A língua, despida de cultura, é um código vazio de significado, 
um amontoado de regras e sons. A cultura tem a capacidade de conferir a uma língua nuances que a tornam única. É a cultura que faz com o que o português do Brasil seja distinto do português de Portugal ou de Moçambique; que o inglês americano, britânico, australiano ou sul-africano tenham peculiaridades que os tornem únicos. A cultura preserva as singularidades e a riqueza de cada povo e de cada língua ou dialeto. Deste modo, nossas salas de aula devem sim ser focos de enriquecimento cultural, pontos de apoio e de convergência de culturas.

\subsubsection{Ensinando cultura}

Nas seções anteriores, discuti o conceito de cultura e estabeleci a relação entre língua e cultura. Mostrei que se despirmos uma língua de sua cultura, restará apenas um código, um sistema de regras e sons pouco significativo para a condução da vida em sociedade. Nesta seção, falarei sobre como a cultura pode e deve ser incluída na sala de aula de língua estrangeira, não como matéria a ser estudada isoladamente, mas como parte integrante dos atos de fala, como mola mestra das interações em qualquer comunidade.

Quando falamos em ensinar cultura, incorremos o risco da interpretação equivocada oriunda de anos ensinando-se geografia, sociologia, história, matemática. O modelo de educação com o qual estamos acostumados, remete ao ensino conteudista, no qual teríamos um livro sobre cultura que traria uma receita pronta de como ela deve ser introduzida nas aulas de língua estrangeira. Isso posto, é necessário estabelecer um pressuposto sem o qual as discussões que teço deste ponto em diante se tornariam inválidas: não há uma formula para se ensinar cultura, assim como não há um currículo com os tópicos culturais que devem ser trabalhados.

Antes de falarmos sobre a cultura em sala de aula, é necessário estabelecermos os conceitos e a importância de conhecimento cultural (cultural knowledge) e consciência cultural (cultural awareness). Tomlinson e Masuhara (In: PEREIRA; GOTTHEIM, 2013) conceituam o conhecimento cultural como informações sobre as características da sua cultura ou da cultura de outrem, ao passo que a consciência cultural seria a percepção que temos acerca dessas culturas. Assim sendo: "Maior conhecimento cultural pode nos dar maior 
credibilidade e expertise. Maior consciência cultural pode nos ajudar a alcançar empatia e sensibilidade cultural (TOMLINSON; MASUHARA In: PEREIRA; GOTTHEIM, 2013, p. 31).

A combinação entre a informação e a percepção da cultura cria condições ideais para que ocorra a aquisição de línguas, uma vez que promove exposição motivada à língua em uso. Como discuto anteriormente, a cultura dá vida à língua, sendo assim, quando um professor tem informações acerca da cultura da línguaalvo e tem empatia pelos membros daquela comunidade linguística, lançará mão desses elementos para promover o uso cultural da língua, ou seja, expor os alunos a situações autênticas de uso da língua para que possam fazer sentido através da língua. Por exemplo, é muito comum vermos alunos iniciantes de inglês reproduzirem o seguinte diálogo: "How are you?"; "I'm fine, thanks. And you?"; "I'm fine, too." O diálogo não é linguisticamente impreciso, pelo contrário, a linguagem está gramaticalmente correta; no entanto, é um discurso artificial. E se o aluno não estiver bem? E se o interlocutor não responder que está bem? Continuaremos fazendo com que nossos alunos memorizem pedaços da língua sem pensar criticamente sobre o que estão fazendo?

Por outro lado, de nada adianta fomentarmos um ambiente no qual o aluno esteja motivado e receptivo à língua e à cultura se não houver um trabalho em sala de aula que seja significativo e relevante para o contexto do aluno. A esse respeito, Almeida Filho (2011, p. 106) diz:

o lugar da cultura é o mesmo da língua quando essa se apresenta como
ação social propositada. A experiência com e na língua-alvo em atividades
envolventes e tidas como relevantes pelos alunos favorece o trabalho pela
consciência cultural do outro e da própria L1 na aquisição de uma nova
língua.

Ou seja, o trabalho de conscientização cultural deve ser contextualizado nas atividades de sala de aula de modo a envolver o aluno que deixa de ser coadjuvante no processo de ensino-aprendizagem e passa a contribuir ativamente para a sua aprendizagem. O aluno, envolvido com a língua e cultura que está adquirindo, constrói seu arcabouço linguístico para usá-lo de maneira significativa. Assim, o aluno se apropria dos scripts da língua e das culturas e as empregas nas interações comunicativas. Acerca da contextualização de aspectos culturais em sala de aula, Fernández (2002) vem acrescentar a necessidade de que essa contextualização 
seja feita a partir do uso específico desses aspectos. Para que a interpretação da mensagem seja feita da maneira correta, deve-se partir de cada situação específica, haja vista que essas situações são culturalmente determinadas.

\footnotetext{
Em síntese: os aprendizes de uma L2 devem possuir um repertório de atos de fala e devem ser capazes de intervir em situações de comunicação real com correção e adequação e, para tanto, a competência sociocultural deve fazer parte de qualquer curso preocupado com o desenvolvimento da efetiva comunicação (FERNÁNDEZ, 2002, p. 42-43).
}

Vale aqui ressaltar que quando falo sobre correção e adequação, não me refiro à gramática ou ao uso de um registro formal, mas sim às escolhas que determinarão o script cultural a ser utilizado. Wierzbicka (2003) elenca os fatores que influenciam essas escolhas: intimidade, proximidade, informalidade, harmonia e sinceridade. A forma como cada comunidade valoriza e reage a cada um desses rótulos determina o script cultural a ser utilizado. Isso posto, Goddard e Wierzbicka (2004, p. 153) definem scripts culturais como sendo "uma nova técnica poderosa de articulação de normas culturais, valores e práticas em termos que sejam claros, precisos e acessíveis tanto para membros de dentro como para membros de fora de uma cultura".

Em outras palavras, os scripts culturais são atos de fala e códigos de interação específicos de cada cultura. Os diferentes modos de falar são reflexo direto das práticas e valores locais. Cada comunidade dá significado a seus scripts culturais de acordo com o que pensa, fala e acredita. Diferentes sociedades têm scripts e práticas diferentes para situações equivalentes de modo que essas ações fazem sentido dentro de uma cultura. Lembro aqui de um aluno afegão que chegou até mim com um dilema cultural. Recém-chegado no Brasil, o diplomata e sua família não falavam português ainda e as aulas de inglês, língua que ele usava correntemente nas reuniões das embaixadas, Ihe serviam como ponte entre a cultura brasileira e afegã. $O$ aluno se aproximou e com a seguinte pergunta: "Professora, se eu colocar um prato de comida no chão, você acharia normal?". A pergunta me pegou de surpresa e continuei a conversa para tentar entender melhor o que o afligia. O problema era que a funcionária da limpeza recolhia os pratos que ele colocava no chão mesmo quando eles tinham comida dentro. Na cultura dele, o chão não é considerado um local sujo, ou de descarte. As pessoas sentam-se no chão ao redor da comida e comem com as mãos, logo, quando ele colocava os 
pratos não chão, não significava que não iria comer mais, no script de sua cultura é assim que as coisas são feitas.

Ninguém questiona seus próprios scripts culturais. Tenho a certeza de que a faxineira recolhia os pratos com a intenção de manter a casa limpa e achava que estava fazendo um bom trabalho e não irritando o patrão. Do mesmo modo que minha avó mineira mantém uma geladeira de doces caseiros para encher a mesa quando recebe alguém para lanchar. Para ela, filha de italianos que imigraram fugindo da guerra e da fome, mesa farta é motivo de orgulho, logo, recusar uma refeição preparada por ela é motivo de grande ofensa. No primeiro exemplo, mostro o caso de uma língua servindo de apoio para interações entre duas outras línguas e culturas distintas. No segundo, mostro como as diferenças culturais podem atrapalhar as relações e a comunicação mesmo entre falantes da mesma língua. Como disse antes, a cultura é historicamente posicionada, acredito que as jovens avós de Minas Gerais considerariam a fartura de Dona Lourdes como um desperdício.

Retomo aqui, então, a necessidade de os professores de língua compreenderem que as posições de sujeito e, consequentemente, as identidades culturais, não são mais estáticas. Isso é fundamental por uma série de razões. Primeiro, tal entendimento faz-se necessário para que os educadores criem na sala de aula um ambiente emocionalmente seguro. Isso é, um ambiente onde os alunos possam tomar novas identidades para si, bem como expressá-las livremente. Além disso, essa percepção da dinamicidade de posições do sujeito é o que permitirá que os aprendizes tenham interações significativas, tanto sociais quanto culturais. Como anteriormente posto, a cultura dá sentido à experiência de cada indivíduo. Logo, o não cerceamento da expressão cultural é condição sine qua non para que o aluno possa ter uma experiência de aprendizagem genuína e profunda. É também dentro do âmbito da cultura que as interações sociais têm seu lugar. $O$ homem enquanto animal social constrói a si mesmo a partir de tais interações. $O$ entendimento do professor de como as identidades são estabelecidas é, então, pedra angular para que os objetivos do ensino de língua anteriormente discutidos sejam verdadeiramente alcançados. 
Assim, ao levar a cultura para a sala de aula, o professor deve estar ciente da realidade na qual os alunos estão inseridos; visto que é nesse contexto que eles vão fazer uso da língua a ser estudada. Segundo Silva, Hall e Woodward (2000, p. 17): "É por meio dos significados produzidos pelas representações que damos sentido à nossa experiência e àquilo que somos". Uma visão reducionista da cultura pode resultar em uma sala de aula na qual os alunos não se veem representados, um local no qual não há espaço para que as vozes individuais dos alunos, com suas múltiplas posições de sujeito, sejam ouvidas. Ao não se identificarem com as identidades culturais propostas pelos materiais didáticos, ou pelo professor, os alunos podem rejeitar os mesmos, o que provavelmente irá limitar o domínio da língua.

É necessário estabelecer a diferença entre conhecer as regras de uma língua e ter domínio da mesma. Quando me refiro ao domínio da língua, incluo aqui a habilidade de compreender tudo o que é falado ou lido e a habilidade de se comunicar, de interagir na língua e de, principalmente, ser capaz de empregar o vocabulário mais adequado a cada contexto bem como o registro apropriado a cada interação. Portanto, ler em uma língua ou conseguir "se virar" em uma viagem de lazer, nesse contexto, não qualificaria como domínio completo da língua. Como vimos anteriormente, a língua se torna viva e significativa quando se reveste de cultura, ou seja, das práticas cotidianas que caracterizam uma comunidade. Sem elas uma pessoa pode aprender uma língua no sentido de compreender as regras e até mesmo ser capaz de aplicá-las, mas não se tem o domínio da mesma.

No entanto, apesar de ser fácil compreender a necessidade de inclusão da cultura na sala de aula, a prática mostra que fazê-lo não é uma tarefa tão simples. Fernández (2002) discorre sobre as dificuldades de se tratar questões culturais na sala de aula de língua estrangeira. Dentre os vários fatores mencionados por ele destacam-se a falta de tempo, os currículos pré-delimitados, livros didáticos que não permitem um trabalho mais aprofundado, e professores que nem sempre conhecem a cultura do(s) povo(s) que utiliza(m) a língua que se estuda. Não é incomum vermos professores tanto da rede pública como da rede privada de ensino no Brasil que acumulam mais de um cargo e que cumprem cargas horárias altas a fim de melhorar o ganho mensal. Quando não é este o caso, temos ainda o fato de que muitos professores sequer participam da seleção do material didático ou da montagem do currículo de suas turmas, e outros tantos que são meros reprodutores das lições 
enviadas pela franqueadora e que, para cortar custos, não são registrados como professores. A inclusão da cultura na sala de aula perpassa por fatores estruturais, administrativos, políticos e econômicos.

Não está entre os objetivos deste trabalho analisar a valorização do professor, mas, como afirma Mendes (In: SANTOS; ALVAREZ, 2010, p. 56),

o ensino/aprendizagem de língua como cultura, insere-se nesse contexto, o de assumirmos, como pesquisadores e professores, uma postura crítica diante da nossa prática; e também de enxergarmos o indivíduo, seja ele aluno ou professor, dentro do contexto no qual vive, age e interage com os outros, com os seus modos particulares de interpretarem o mundo à sua volta.

Sendo assim, não é possível falarmos sobre o processo de ensino/aprendizagem ignorando a posição do professor, o mediador cultural entre a cultura do aluno e a cultura trazida pela língua estrangeira a ser estudada. É na presença do professor que surgirão os estranhamentos culturais e é dele a responsabilidade de fazer da sala de aula um ambiente neutro e seguro para que os alunos possam debater questões que concernem essas diferenças. Juntos, professores e alunos devem promover com o material didático, ou apesar do material didático, o conhecimento e a consciência cultural. Afinal, "aprender cultura é um processo de criar significado compartilhado entre representantes culturais" (BROWN, 2007, p. 194).

\subsection{Material didático de Língua Estrangeira}

$\mathrm{Na}$ subseção sobre imperialismo linguístico falo sobre a importância do material didático de inglês para a economia da Inglaterra. O próprio conselho Britânico confirma que o inglês é o ouro negro do Mar do Norte. No capítulo a seguir abordo alguns aspectos que caracterizam o material didático para adolescentes, haja vista que a produção de material para esse público e outros públicos específicos é relativamente recente. Falo também sobre a relação do professor com o material didático, uma parceria conturbada, porém possível. 


\subsubsection{Material didático para adolescente}

Antes de falarmos sobre o material didático produzido para adolescentes, é necessário estabelecer a faixa etária à qual estou me referindo. Para fins desta pesquisa, adotarei a definição proposta pela Lei n. 8.069, de 13 de Julho de 1990, também conhecida como Estatuto da Criança e do Adolescente (ECA). O artigo segundo da lei considera como criança a pessoa até doze anos incompletos e adolescente a pessoa entre doze e dezoito anos de idade. Culturalmente, uma faixa etária que começou a ser percebida como formadora de opinião ou como potencial mercado consumidor na modernidade. Assim, ao fazer uma busca pela origem dos materiais didáticos produzidos especificamente para o público adolescente, encontrei várias barreiras.

Encontrei, no entanto, algumas publicações que fazem um detalhado trabalho de descrição da história do ensino de língua inglesa no Brasil, tais como: Márcia Nogueira (2007), em Ouvindo a voz do (pré) adolescente brasileiro da geração digital sobre o livro didático de inglês; Vera Lúcia Menezes de Paiva (In: DINIZ; VILELA, 2009), em Ensino de língua inglesa: antecipando uma pedagogia pós-moderna; e, Ricardo Jucá (2010), em A língua inglesa no ensino secundário brasileiro: 1838-1930. O primeiro trabalho descreve o desenvolvimento dos cursos de línguas e a evolução dos materiais nacionais e importados adotados. O segundo descreve a trajetória da autora brasileira, Solange Ribeiro, pioneira na produção de livros didáticos com conteúdo sobre o cotidiano nas diversas regiões do Brasil. O terceiro, faz uma descrição detalhada de todos os decretos que regeram o ensino de inglês nos colégios do Brasil entre 1838 e 1930. No entanto, não foi possível precisar quando os materiais para o público adolescente começaram a ser produzidos ou distribuídos.

Os primeiros sinais de livros para faixas etárias específicas ocorrem com a criação de livros para crianças. Uma pesquisa histórica mais aprofundada, e a visita às bibliotecas dos primeiros cursos de línguas do país, o Colégio Pedro II e a Cultura Inglesa do Rio de Janeiro poderiam trazer respostas a essas questões por ora não contempladas ou não encontradas pela autora que lhes dirige nos trabalhos publicados em bases de dado nacionais e internacionais. 
Para fins do debate realizado neste estudo, farei um breve apanhado histórico do ensino de línguas no Brasil segundo os estudos de Nogueira, Paiva e Jucá com o intuito de retratar uma caminhada que permita a continuidade das análises propostas por mim. Os parágrafos seguintes levarão à construção de uma linha do tempo que nos dará um recorte cronológico mais preciso do início da utilização de materiais voltados para o público adolescente no Brasil.

Iniciamos nossa trajetória com os jesuítas, responsáveis pelos primeiros sistemas de ensino no Brasil. Segundo Nogueira (2007), eles exerceram o monopólio da educação brasileira do século XVI ao século XVIII. Os livros em latim vinham da Europa a pedido dos missionários, mas a falta de domínio da língua por parte de alguns religiosos os levava a solicitar livros em outras línguas. "em 1593, o padre João Vicente Yate encomendou livros a Lisboa em outros idiomas, principalmente em inglês e espanhol" (NOGUEIRA, 2007, p. 25-26). Acredita-se que essa pode ter sido a primeira importação de um LD em inglês, não de ensino de inglês, para o Brasil.

Ainda conforme Nogueira (2007, p. 21):

O ensino formal da língua inglesa no Brasil teve início com o decreto de 22 de junho de 1809, assinado pelo Príncipe Regente de Portugal, que mandou criar uma escola de língua francesa e outra de língua inglesa. Até então, o grego e o latim eram as línguas estrangeiras ensinadas na escola.

Outra resolução do mesmo ano foi registrada por Jucá (2010). Em 14 de julho de 1809, preocupado com a manutenção dos acordos comerciais, o Príncipe Regente determinou a criação das "Aulas Régias" de línguas "vivas", criando-se assim uma Cadeira de Língua Francesa e uma Cadeira de Língua Inglesa. Essas decisões beneficiavam diretamente à burguesia e permitia a formação de profissionais que dominassem as línguas que garantiam a continuidade das relações comerciais. No final da década, em 08 de abril de 1899, o Regulamento para o Gymnasio Nacional é criado com o objetivo de preparar os jovens para seus deveres de cidadão e cumprir os pré-requisitos necessários para ingresso nos cursos de ensino superior: bacharelado em ciências e letras. 
Jucá (2010, passim) faz um estudo histórico no qual transcreve trechos de documentos originais registrando o ensino de inglês no Brasil de 1838 a 1930. Neste trabalho, o autor mostra a evolução do ensino baseado em gramática e tradução, no qual os alunos, a partir do terceiro ano, estudavam clássicos da literatura inglesa. $O$ autor mostra ainda decretos de contratação de professores (nativos, naturalmente) e normas que pautavam a criação de materiais didáticos pelos próprios professores. No período por ele descrito, fica clara a preocupação com a formação de cidadãos distintos, aptos a assumirem papel de destaque na sociedade da época. Além de inglês, estudava-se latim, grego, francês e alemão, com carga horária que variáva de acordo com o currículo vigente no período. Os exames de acesso à academia: cursos superiores de direito e medicina, regulavam o que acontecia nas salas de aula. No Brasil República, "o Programa de Ensino de Inglês indicado para o terceiro e quarto ano inclui gramática elementar, leitura, tradução e versão fácil para focar exercícios de conversação" (JUCÁ, 2010, p. 89).

Mudanças significativas não só no conteúdo, mas na metodologia de ensino de línguas estrangeiras ocorreram em 1930 com a criação do Ministério de Educação e Saúde Pública e em 1931 com a Reforma Francisco de Campos. Nogueira (2007, p. 22) assim comenta os efeitos da reforma:

\begin{abstract}
Quanto ao conteúdo, esta reforma aumentou, de modo indireto, a ênfase dada às línguas modernas em função da diminuição da carga horária do latim. No que diz respeito ao método, as mudanças foram mais profundas, na medida em que essa reforma introduzia oficialmente o ensino das línguas estrangeiras através das próprias línguas. Esse método, que recebeu o nome de 'método direto', já havia sido introduzido na França 30 anos antes.
\end{abstract}

A primeira metade do século $X X$ foi marcada pelo lançamento de LDs brasileiros para diversas matérias, no entanto, os LDs de inglês continuaram sendo importados. Oliveira (1999, p. 27 In: NOGUEIRA, 2007, p. 27) menciona que o Decreto n. 20.833, de 21 de dezembro de 1931, que instituiu o método direto sugeria também os autores que deveriam ser lidos na última série de inglês:

Dickens - David Copperfield, Emerson - Essays, E. Poe - Tales, George Eliot - Silas Marner, Goldsmith - The Vicar of Wakefield, Jerome K. Jerome - Three men in a boat, Kipling - Plain tales from the hills, Lamb - Tales from Shakespeare, Mark Twain - Life on the Mississipi, Shakespeare - Julius Caesar, Stevenson - The art of writing, e Thackeray - The four Georges. 
Até então, a língua inglesa era oferecida como parte integrante do currículo dos colégios, não havendo registro oficial da criação de cursos de línguas. O cenário do ensino de língua inglesa mudou em 1934 quando, com o apoio da Embaixada Britânica no Brasil, foi fundada a Sociedade Brasileira de Cultura Inglesa no Rio de Janeiro com a missão de difusão no país: "da língua e das manifestações de pensamento, ciências e artes inglesas (DIAS, 1999, p. 89 In: NOGUEIRA, 2007, p. 22). Esse evento marca o nascimento dos centros binacionais e das escolas de línguas no Brasil.

Em 1942, segundo Richards e Rogers (1993), em um programa de treinamento do exército americano, originou-se o audiolingualismo. A metodologia, que tinha como suporte o behaviorismo, preconizava a formação de hábitos e a repetição de estruturas linguísticas. No Brasil, no entanto, a gramática e a tradução, assim como o método direto, continuaram presentes nas salas de aula por várias décadas, conforme o registro Paiva (In: DINIZ; VILELA, 2009, p. 327):

No início dos anos 70, apesar da notoriedade da metodologia áudiooral, ou áudio-lingual, nos Estados Unidos, ainda conviviam, no Brasil, o ensino de gramática e tradução e o método direto que almejava o desenvolvimento da fala.

Segundo Paiva (In: DINIZ; VILELA, 2009), os LDs que davam vida ao método direto, "Spoken English", "New Spoken English" e a coleção "Essential English", da editora Longman, continuaram em uso durante vários anos. A abordagem áudio-lingual, segundo o mesmo autor ressalta, chega ao Brasil no final dos anos 1960 e início dos anos 1970 com as coleções "English 900" (1964) e "English 901" (versão inglesa) e "New Concept English". Estive com os livros mencionados em mãos durante minha pesquisa e nenhum deles apresenta indicação de ser voltado para o público adolescente. Os diálogos, alternados entre professor e alunos, são repetições mecânica de situações cotidianas. Os temas abordados se referem ao trabalho e à vida em sociedade. O foco é a produção de fragmentos de linguagem e o público-alvo é genérico.

É importante ressaltar que o adolescente não tinha papel relevante na sociedade até então. Os adolescentes, nada mais eram do que jovens adultos se preparando para o mercado de trabalho. A adolescência era uma espécie de limbo, um purgatório entre a infância e a vida adulta. Coutinho (2005, p. 17) analisa a 
construção histórica do conceito de adolescência e pontua que a falta de um lugar predeterminado para os adolescentes na sociedade imposta pelo processo de formação profissional e pelos padrões atuais de casamento e família geraram esse tempo de espera, essa fase de passagem:

a adolescência é fruto de um enigma relativo à passagem da infância para a vida adulta na sociedade ocidental moderna. [...] Portanto, o que ocorre com a adolescência é justamente o oposto daquilo que outras culturas ritualizam coletivamente através dos rituais iniciáticos.

Não é preciso ir muito longe para vermos as diferenças entre a adolescência de hoje e a de outrora. Duas gerações antes da minha as mulheres desta idade já eram casadas e tinham filhos, os homens, consequentemente, já ocupavam uma vaga no mercado de trabalho. Segundo Coutinho (2005, p. 18), o adolescente ganha a cena a partir da década de 1960:

Desde os movimentos libertários propriamente ditos, cujo protótipo é a contracultura americana, a difusão do rock'and'roll, o advento da pílula, até o surgimento da calça jeans; tudo isso contribui para uma verdadeira revolução nos modos e costumes que regulam as trocas entre as gerações, anunciando profundas alterações no laço social e nos ideais que 0 sustentam.

Essa nova personagem surge na sociedade com a promessa de um novo nicho, um novo mercado consumidor e, portanto, público-alvo potencial para diversos produtos, inclusive LD de inglês. O período da história que aqui se inicia viu uma explosão de materiais didáticos e de novas metodologias, seja através das grandes editoras, ou por parte das franquias de idiomas. É justamente por essa abundância de materiais, que fica difícil precisar o momento exato do surgimento do primeiro livro didático direcionado para o público adolescente. Em 1973, Paiva (In: DINIZ; VILELA, 2009) registra o lançamento da segunda edição de $A$ Trip to the Moon, de Solange Oliveira. A autora mineira, também responsável pela publicação de "Structural English", um sucesso editorial com mais de onze edições, tinha como público-alvo as crianças.

Segui os relatos de Paiva, de 1973, acerca do trabalho de Solange, na expectativa de encontrar evidências de um livro para adolescentes, no entanto, não encontrei trabalhos que me trouxessem uma resposta definitiva. Portanto, as colocações que faço deste ponto em diante são limitadas pelas restrições da 
presente pesquisa e são passíveis de serem corrigidas por pesquisas de cunho histórico que possam ser publicadas após a defesa dessa dissertação. Assim, a próxima publicação de Solange, The Blue Earth, de 1979, também voltada para o público infantil, tem como objetivo levar o aluno ao nível pré-intermediário.

A trajetória de Solange nos leva a 1980, quando ela publica o que pode ser o primeiro livro de inglês para adolescentes escrito e publicado por uma autora brasileira. Paiva (In: DINIZ; VILELA, 2009, p. 345), assim o descreve:

\begin{abstract}
A Tour of Brazil é uma série, em dois volumes, destinada a adolescentes brasileiros e, segundo o texto de apresentação do material, é uma realização pioneira por utilizar a cultura brasileira para a aprendizagem da língua inglesa; por propor uma integração com outras disciplinas; pelo desenvolvimento da leitura silenciosa e da interpretação de texto desde o início; pela conciliação da gradação gramatical aliada a abordagem nocional-funcional; pela adoção de uma abordagem centrada no aluno; e, finalmente, pelo mínimo de material introduzido em aula e o máximo de trabalhos em casa.
\end{abstract}

O material, bastante vanguardista enquanto metodologia e proposta, desloca, segundo Paiva (In: DINIZ; VILELA, 2009), a periferia para o centro ao trazer personagens ingleses que visitam o Brasil e exploram seus pontos turísticos e festas tradicionais. Uma característica marcante do trabalho de Solange é a preocupação com o papel educador do ensino de línguas: "Uma preocupação constante da professora era tornar o estudo do inglês menos alienado, sempre preocupada com a função educacional do ensino de línguas" (PAIVA In: DINIZ; VILELA, 2009, p. 345). Retomarei o trabalho de Solange nas análises, onde traço um paralelo entre a proposta que alia educação e pensamento crítico ao ensino de línguas, com a proposta da coleção Time Zones.

Minha pesquisa pelo primeiro livro no mercado editorial brasileiro voltado para o ensino de língua para adolescentes, sugeriu alguns títulos: Success with English, 1970; Access to English, 1978; English for a Changing World, 1976. No entanto, a pesquisa é inconclusiva e aponta para a necessidade de um trabalho com histórico mais extenso. Meu primeiro livro de inglês enquanto aluna foi Sam on Radio 321, de 1981, seguido de Touchdown, de 1991, também meu primeiro livro enquanto professora em 1999. Em uma consulta a membros do Braz-Tesol, colegas de profissão, e a bibliotecas de cursos de línguas em Brasília, Distrito Federal, e em Uberaba, Minas Gerais, não encontrei cópias físicas de publicações internacionais mais antigas para adolescentes. Fica aqui registrada a necessidade de pesquisas 
históricas acerca dessas publicações. Coloco, a seguir, a linha do tempo criada por mim para simbolizar a trajetória que leva à utilização de livros didáticos de língua inglesa voltados para o público adolescente no Brasil. 


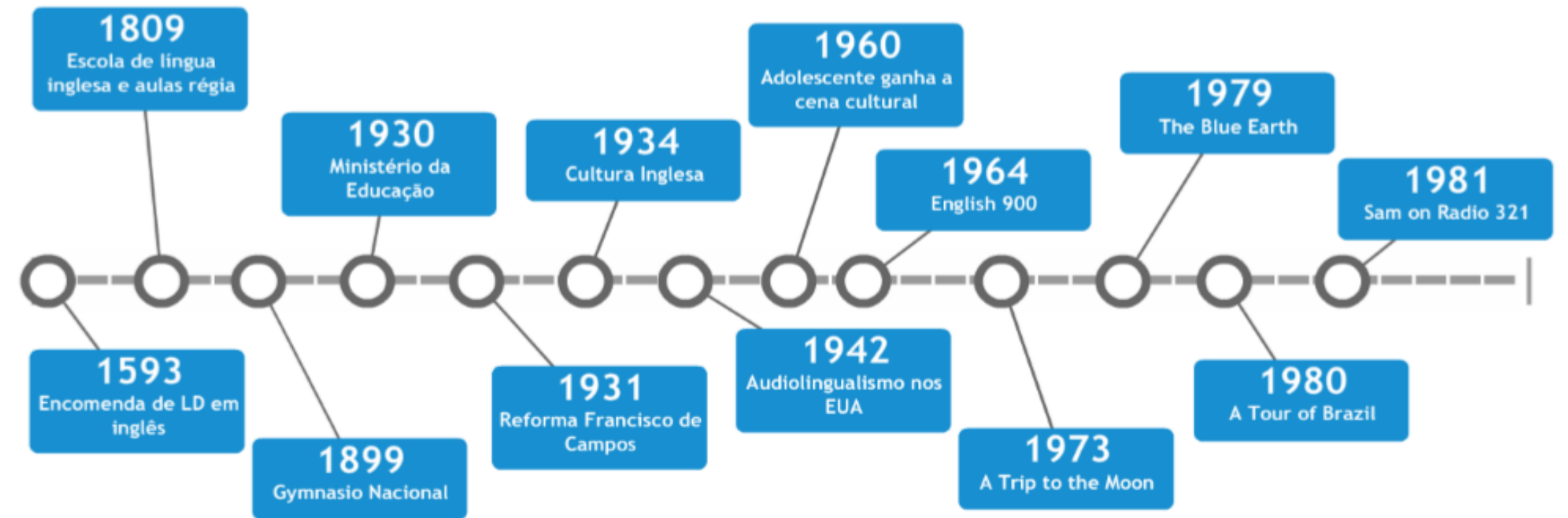

Onde: 1593 - Padre João Vicente Yate encomendou a Lisboa LD em inglês; 1809 - Decreto de 22/06 determina a criação de uma escola de língua francesa e uma de língua inglesa. Decreto de 14/07 determina a criação das aulas régias de línguas "vivas"; 1899 - 08/04 - Regulamento para o Gymnasio Nacional; 1930 - Criação do Ministério da Educação e Saúde Pública; 1931 - Reforma Francisco de Campos traz mudanças na metodologia do ensino de línguas estrangeiras: "Método Direto"; 1934 - Fundação da Sociedade Brasileira de Cultura Inglesa; 1942 - Surgimento do audiolingualismo nos EUA para treinamento do exército americano; 1960 - Adolescentes ganham a cena cultural com o rock, a pílula e a calça jeans; 1964 - Publicação do livro English $900 ;$ método áudio-lingual; 1973 - Solange Oliveira publica o livro infantil $A$ Trip to the Moon; 1979 - Solange Oliveira publica o livro infantil The Blue Earth; 1980 Solange Oliveira publica o livro A Tour of Brazil, voltado para adolescentes; 1981 - A editora Longman publica o livro didático para adolescentes Sam on Radio 321.

Figura 1 - Trajetória dos livros didáticos de língua inglesa no Brasil.

Fonte: Da autora dessa dissertação. 
A linha do tempo mostra um caminho marcado por leis e decretos que, por muitas vezes, adiaram a entrada de novas abordagens de ensino no Brasil. Temos registro do uso de gramática e tradução no Brasil muito depois da implementação do Método Direto na Europa. Vemos também um longo período entre o surgimento do audiolingualismo e nos EUA e sua implantação no Brasil através do livro English 900. A franquia CCAA, de 1961, não incluída na figura por falta de dados comprobatórios, também foi responsável pela consolidação do método áudio-lingual, foi ela a primeira franquia brasileira de escolas de inglês, inovando ao produzir o seu próprio material.

\subsubsection{O professor e o material didático}

Discuti, no subcapítulo anterior, o caminho que levou à produção de livros didáticos voltados para o público adolescente, no entanto, o livro didático e, em uma esfera maior, o material didático, englobando aqui todos os recursos que acompanham o livro (vídeo, áudio, flashcards, posters, fantoches, plataformas interativas, dentre outros) constituem apenas ferramentas de apoio ao professor que, junto com o aluno, protagoniza o processo de ensino-aprendizagem. Muito foi dito com relação ao papel do professor no processo de ensino/aprendizagem de línguas: sua responsabilidade enquanto mediador cultural, o imperativo de se conhecer o contexto sociocultural dos alunos, a importância de se promover um ambiente de sala de aula no qual os alunos possam negociar suas identidades com liberdade, e até mesmo a necessidade de se complementar o material didático adotado. Sem a pretensão de eximir o professor das responsabilidades supracitadas, este trabalho se propõe a levantar questões concernentes às representações culturais trazidas por livros didáticos, adotando uma postura realista com relação ao grau de adaptação que cada material exige, visto que "a produção de materiais didáticos dá trabalho e pressupõe exigências" (ALMEIDA FILHO, 2012, p. 62). Exigências essas, muitas vezes difíceis de conciliar com a prática de sala de aula. 
A produção, ou até mesmo a escolha do material didático, deveria ser feita, idealmente, após a avaliação das necessidades individuais de cada grupo de alunos. No entanto, sujeito a uma série de normatizações propostas pela instituição onde trabalha, o professor, grande parte das vezes, sequer participa do processo de seleção do material com o qual vai trabalhar, restando a ele adaptar e complementar o material da melhor forma possível. A esse respeito, Almeida Filho (2012, p. 61) defende que:

\footnotetext{
Adotar equivale a subscrever eventuais pressupostos de fundamentação e atividades julgadas apropriadas para toda e qualquer situação do ensino dessa língua, ainda que se prevejam inserções, cortes e adaptações dos professores adotantes a título de complementação.
}

Assim sendo, independentemente de ter participado da escolha deste material, recai sobre o professor a tarefa de complementá-lo. E, "embora a maioria dos professores de língua estrangeira sonhe com o livro didático perfeito, a maioria reconhece a futilidade de tal prospecto" (JOHNSON, 1995, p. 136). Assim, à medida que a oferta de materiais cresce, cresce também a preocupação com a influência que esses materiais exercem com relação ao conteúdo e a forma como ensinamos.

Em cenários de ensino de inglês como língua estrangeira, professores não nativos acabam por recorrer ao livro didático como principal fonte de informação acerca da língua e das culturas inglesas. "Portanto, professores de EFL podem depender grandemente dos materiais comerciais no desenvolvimento de seu currículo, no planejamento de suas aulas e atividades" (JOHNSON, 1995, p. 137). Os alunos também se encontram nessa dependência, especialmente os de EFL, visto que os alunos em contexto de ESL podem recorrer ao ambiente que os cerca como fonte de repertório cultural. Um aluno imerso na cultura da língua que está estudando bebe água da fonte em termos de cultura, por assim dizer, pois está inserido na cultura da língua que está estudando. O aluno de EFL, por sua vez, depende dos encontros de aula, muitas vezes a sua única oportunidade de contato com a língua, para conhecer mais sobre os scripts culturais que permeiam a língua estudada. Uma outra questão colocada por Johnson, diz respeito ao uso de materiais de ESL para alunos de EFL, o que pode ser inadequado considerando-se que o ambiente no qual o aluno está inserido sofre influências culturais diferentes. 
Johnson (1995) reconhece os materiais comerciais como fonte rica de conteúdo linguístico e cultural para ambos alunos e professores. No entanto, aquele autor enfatiza que o livro sozinho não tem os elementos científicos ou tecnológicos para ensinar uma segunda língua. Cabe assim ao professor olhar criticamente para o seu conteúdo a fim de determinar a sua adequação para cada grupo de alunos e adaptar o currículo ou complementá-lo para satisfazer as necessidades e objetivos dos alunos.

A essa ideia, Sternfeld (In: ALMEIDA FILHO, 2009, p. 53) vem acrescentar:

\begin{abstract}
Há uma visão corrente de matérias como produtos prontos, feitos por especialistas, que determinam o começo, meio e fim de um processo. Ela antevê um professor técnico, aplicador de decisões conteudísticas e metodológicas tomadas previamente sobre um ensino generalizado para todos os contextos. Há, outrossim, a ilusão do material didático ser fonte única de insumo a ser explorado, no sentido de condensar um saber conteudístico e metodológico consagrado. No entanto, essa questão vem sendo repensada, pois colide com as reais necessidades de professores e alunos de gerar língua em uso dentro de contextos específicos.
\end{abstract}

Quanto mais personalizado for o ensino, mais difícil será de se encontrar um material didático que atenda plenamente às demandas de conteúdo, língua e cultura de uma turma.

O conteúdo e as atividades propostas em tais materiais não previam o surgimento de uma atitude pedagógica em sala de aula que enalteceria, por um lado, a contribuição gerada pelo insumo de alunos, vistos como seres únicos, sociais, informados, vividos, e por outro lado, o ritmo processual de aprender de cada aluno (STERNFELD In: ALMEIDA FILHO, 2009, p. 52).

O professor tradicional, detentor do saber e transmissor de conhecimento, vem gradualmente sendo substituído pelo professor mediador, aquele que monitora o trabalho desenvolvido pelo e para o aluno. Esse modelo de sala de aula traz para o centro o aluno como gerador de conteúdo, como ser pensante e bastante capaz de trazer sua experiência de vida e seu contexto social, independentemente da idade, para dentro da sala de aula e, a partir dessa experiência, gerar saberes com a mediação de um professor.

Poderíamos então dizer, por este ângulo, que se essa visão fosse adotada de maneira extrema, estaríamos caminhando para a extinção do material didático ou pelo menos para o uso parcimonioso do mesmo. Caminhamos para a produção de materiais mais flexíveis, com atividades que possam ser adaptadas a diversos 
contextos. Em uma visão um pouco Darwinista, os materiais serão adaptados a essa nova realidade a fim de prevenir a extinção do livro didático e a fim de atender aos muitos interesses por trás de um mercado editorial demasiadamente frutífero como o de materiais de língua inglesa.

Para Batista (2003, p. 49 In: ROJO In: MOITA LOPES, 2013, p. 173), o contexto educacional contemporâneo é

marcado pela afirmação da diversidade e flexibilidade das formas de organização escolar, originadas pela necessidade de atender aos diferentes interesses e expectativas gerados por fatores de ordem cultural, social e regional. Para isso, é necessário dispor de um livro didático também diversificado e flexível, sensível à variação das formas de organização escolar e dos projetos pedagógicos, assim como à diversificação das expectativas e interesses sociais e regionais.

O desafio então fica na produção ou adoção de um livro diático (LD) que traga atividades que valorizem a produção do aluno, atividades que permitam que o aluno gere conteúdo e interaja com o conteúdo de modo a trazer para a sala de aula a sua própria cultura. Ao assumir o papel de agente cultural, seja por meio de projetos ou de atividades menos estruturadas, o aluno deixa de ser receptor passivo da cultura do outro e a sala de aula passa a ser um espaço de diálogo entre a cultura do aluno e a cultura da língua a ser estudada.

Vários materiais didáticos trazem abordagens simplificadas de cultura nas quais estuda-se "sobre" a cultura e não "na" cultura. Nestes materiais, "a apresentação de aspectos culturais se dá frequentemente por meio de 'curiosidades culturais"' (KAWACHI; LIMA In: ROCHA; MACIEL, 2013, p. 92). A diferença entre as duas posições está no que Almeida Filho (2011, p. 106) pontua a seguir: "Num caso, a língua é foco real, e a cultura é a franja. No outro, a cultura é o cerne, e a língua é o que vem depois dela". Enquanto formos consumidores de curiosidades culturais, manteremos a visão limitadora de que existe somente a "nossa cultura" e a "cultura deles", eliminando as possibilidades de diálogos entre elas e a apropriação de ambas pelos agentes envolvidos neste processo. 


\subsection{Representação cultural em materiais didáticos de Língua Estrangeira}

No capítulo anterior, fiz um breve histórico do material didático de língua estrangeira no Brasil e do início da produção de conteúdo voltado para o público adolescente. Em seguida, tratei de aspectos concernentes à relação do professor com o livro didático, bem como os efeitos que as mudanças decorrentes da inversão de papéis na sala de aula podem ter sobre o mercado editorial. No subcapítulo seguinte, trago a influência que $o$ autor, suas crenças e culturas podem ter sobre $o$ conteúdo do livro didático. Abordo também os estereótipos culturais e a sua presença marcante nos livros e nas salas de aula.

\subsubsection{Crenças e cultura do autor e sua influência sobre o material didático}

O conhecimento é um bem abstrato. Não se pode comercializar o saber. Podemos, no entanto, adquirir cursos e aulas, na esperança de que, através dessas aulas, adquiramos conhecimento. No entanto, as horas que um professor tem disponíveis são limitadas ao tempo do seu dia e, os ganhos advindos das aulas, limitados. Qual seria então a solução capitalista para se obter lucro com educação? A produção e comercialização de materiais didáticos. A materialização da educação ou do conhecimento se dá através do material didático, um bem de produção seriada que exime o produtor do desgaste advindo das frustrações do cliente (alunos, famílias, coordenadores). Afinal, o conhecimento, produto esperado dessas aulas, não pode ser garantido por quem as comercializa e as frustrações do aluno recaem, inevitavelmente, sobre o professor. Segundo Almeida Filho (2012, p. 59):

\footnotetext{
Materiais didáticos são particularmente materializáveis e, por isso, se converteram num filão milionário de lucros no caso de grandes séries didáticas, especialmente internacionais postas à venda no mercado para atender o ensino de idiomas de larga oferta no mundo.
}

Quando o autor fala em larga escala, especialmente em escala mundial, percebo que sobra pouco espaço para a personalização das práticas de sala de aula. Recapitulando o que discutimos sobre cultura, existe uma necessidade pedagógica atual de se estar atento para as individualidades culturais de cada aluno e de cada grupo. Como isso seria possível com um material destinado a cinco 
continentes diferentes? Ao se produzir um material e distribuir a mesma edição para todos os cantos do globo ou, quando muito, distribuí-lo em versão americana e britânica, reduz-se o ensino de cultura ao estudo dos "tipos comuns". Condicionamos, assim, o ensino ao material didático adotado. Nas palavras de Almeida Filho, (2012, p. 59-60):

quando se compra um MD pronto para uso, compra-se junto uma filosofia de ensinar que tem marca indelével no processo de ensino e até certo ponto no de aquisição ou aprendizagem que fica por conta dos alunos. [...] ninguém poderá fugir com facilidade da força centrífuga da abordagem dos autores que anima os MD adotados.

Ao invés de o professor optar pelo método, sequência de tópicos e conteúdos que melhor atendem às demandas de seu grupo de alunos, essas decisões passam a ser de responsabilidade dos autores do livro didático.

O que sucede é que os autores, ao tomar decisões referentes: (a) ao lugar ocupado pelas sistematizações na unidade; (b) à escolha de tópicos gramaticais (geralmente sequenciados); (c) à coesão estabelecida entre eles; (d) à incidência com que determinado aspecto aparece; e (e) à maneira como é trabalhado, projetam e impelem, diretamente nos materiais e, indiretamente na aula do professor, interferências metodológicas (STERNFELD In: ALMEIDA FILHO, 2009, p. 52).

É a contramão do que discutimos anteriormente. É tirar a autonomia dos alunos e professores em prol do sucesso comercial das grandes editoras. É garantir que o inglês seja a maior riqueza do Mar do Norte. Ao subscrever ao que preconiza o livro didático em detrimento da cultura e do contexto no qual professor e aluno estão inseridos, deixamos de ver o aluno como criador, gerador de conteúdo. A motivação do aluno é diretamente influenciada pela conexão que ele faz com o conteúdo apresentado, quando não há conexão, a motivação é reduzida e, consequentemente, a aprendizagem é afetada.

Sobre a função norteadora que o material didático possui sobre o trabalho do professor, Zacharias (2010, p. 30) argumenta que os "livros didáticos de línguas exercem um papel único de empoderamento ou desempoderamento das identidades no aprendiz de EFL". A autora pontua ainda que os livros didáticos dão aos alunos opções limitadas de identidades ao trazerem a figura de um aprendiz de línguas idealizado, materializado na figura de um homem branco, heterossexual, de classe média, livre de problemas. Portanto, eles negligenciam as diferenças entre os 
aprendizes no tocante ao gênero, à raça, à etnia, à orientação sexual, a crenças religiosas, entre outros.

Para que os alunos não sejam privados dos recursos linguísticos necessários à livre escolha e negociação de suas identidades dentro da sala de aula, os professores devem reconhecer a diversidade e abrir espaço durante as aulas para a problematização das diferenças. Segundo Zacharias (2010, p. 31),

as interações 'simplistas' e 'estereotipadas' ilustradas nos livros didáticos podem influenciar e, por vezes, até moldar a motivação dos alunos, o grau de envolvimento com a língua e cultura alvo, e o desenvolvimento de sua competência intercultural.

Por competência intercultural, a autora entende a habilidade de transitar entre uma cultura e outra, entre uma língua e outra; ou seja, a capacidade de escolher os scripts culturais mais adequados a cada situação comunicativa. Um estereótipo cultural no livro didático pode influenciar na constituição da competência intercultural do aluno, o que pode gerar ruídos na comunicação. Os estereótipos culturais serão retratados na seção seguinte a fim de que possamos compreender melhor os efeitos que a presença desses estereótipos no material didático podem ter sobre a aquisição de línguas.

\subsubsection{Estereótipos culturais}

$\mathrm{Na}$ seção anterior, falei sobre a influência que a visão de mundo e das crenças do autor tem sobre o livro didático e, consequentemente, sobre o professor e sua sala de aula. Na presente seção, explicarei melhor o que são esses personagens que personificam o que chamamos de estereótipos culturais. Antes de discutirmos os estereótipos culturais, vou, primeiramente, conceituar o termo estereótipo.

Segundo Brown (2007, p. 191): "Um estereótipo designa características de um grupo a indivíduos puramente com base na sua membresia cultural". Harkot-dela-Taille (In: ARANTES, 2003, p. 178) vale-se de uma terminologia mais acessível para trazer o mesmo conceito: "chamamos estereótipos culturais aqueles 'tipos' tão frequentes que até têm nome". Um estereótipo seria, portanto, um indivíduo simplificado, despido de suas particularidades para que possa figurar como membro 
típico de um grupo maior. Ainda a esse respeito, Brown (2007, p. 190-191) assevera que:

influenciados por nossa própria visão de mundo culturalmente orientada, nós muito frequentemente fazemos uma imagem supersimplificada de outras culturas, agrupando as diferenças culturais em categorias exageradas, para então ver cada pessoa de uma cultura como possuidora de traços estereotipados.

O estereótipo não é uma criação livre que visa deturpar a imagem do outro. Pelo contrário, existem sim, características reais de uma cultura retratadas pelo estereótipo. No entanto, a sedimentação dessas características limita os papéis e identidades dentro de uma sala de aula. Brown (2007) defende que o estereótipo possa até fazer uma imagem precisa ao retratar o exemplo típico de uma cultura, mas que ele erra ao desconsiderar as singularidades da personalidade de cada um. Não se podem usar os padrões de uma cultura para prever o comportamento de indivíduos, pois fazendo isso estaríamos fazendo um julgamento precipitado e equivocado desta pessoa.

Kawachi e Lima (In: ROCHA; MACIEL, 2013) reforçam que práticas culturais como vestuário, arte, gastronomia e identidades sociais apresentadas em LDs não configuram um estereótipo. Para aqueles autores,

o problema da inclusão de apenas imagens culturais "tradicionais" no ensino-aprendizagem de LE (especialmente em LDs) está na desconsideração de práticas culturais de grupos marginalizados em prol da apresentação somente de expressões culturais legitimadas, que favorecem os interesses exclusivamente de uma classe: a dominante. Nesse sentido, há uma simplificação e/ou generalização da realidade, o que acaba por distorcê-la, podendo gerar estereótipos (KAWACHI; LIMA In: ROCHA; MACIEL, 2013, p. 97).

É necessário considerar também que o universal tem o seu lugar ao sol, contanto que ele seja verdadeiramente universal e livre de toda e qualquer ideologia que possa privilegiar um grupo em detrimento de outro. Wierzbicka (2003, p. 67) discute isso:

Não haveria nada de errado em se focar em aspectos universais ao invés de aspectos culturalmente específicos do uso da língua - se a busca por universais for uma posição verdadeiramente universalista e independente de cultura. Mas, como vários estudos recentes tem mostrado, as ferramentas conceituais básicas utilizadas e introduzidas por Brown e 
Levinson (especialmente o conceito de 'face') tem, de fato, uma forte tendência anglocêntrica.

Ao mencionar o conceito de "face", a autora se refere à ideia de preservação da face, ou seja, de a pessoa preservar-se para que não seja alvo de uma situação embaraçosa. O que a autora coloca é que a noção do que é ou não constrangedor é, na maioria das vezes, pautada por um padrão anglocêntrico, ou seja, um padrão de países de língua inglesa. As restrições e scripts culturais são percebidos dentro de um contexto específico de falantes de língua inglesa. Novamente, a determinação do que é permitido ou não, daquilo que traz constrangimento ou não é culturalmente orientado. Uma ação considerada embaraçosa dentro de uma cultura, pode não sêlo em outra. Exemplos disso podem facilmente ser identificados de uma cultura para a outra: o uso ou não de talheres, a forma como se cumprimenta, o modo de vestir, a interação entre pessoas de sexo oposto, entre outros. Ao adotarmos o padrão anglocêntrico como a medida desejável para todas as interações culturais, geramos o que Harkot-de-la-taille (In: ARANTES, 2003, p. 187) chama de um "eles cultural" e um "nós cultural", uma relação regulada pelo medo e pela vergonha. Existe portanto a formação de grupos cuja valorização social é assimétrica e, portanto, indesejável para a sala de aula.

Baladeli (In: FERREIRA 2014, p. 233) defende que as representações que o aluno tem de si e de sua raça afetam a identificação dele com a língua que está aprendendo:

\begin{abstract}
Ao deparar-se com textos verbais e não-verbais que, implícita ou explicitamente, denigrem ${ }^{3}$ a imagem de determinados grupos sociais, 0 aluno estará acessando um conjunto simbólico de valores culturais que não são a medida de todas as coisas, mas que, sim, foram construídos ideologicamente ao longo das relações de poder como uma forma de dominação e de ampliação de sua influência sobre os outros sujeitos e ou grupos sociais.
\end{abstract}

Ao se sentirem parte do grupo de menor prestígio, os alunos podem simplesmente rejeitar a língua e, consequentemente, se recusarem a participar das interações de sala de aula. A língua estrangeira passará a ser uma língua que não Ihe representa. Vale salientar que desde Durkheim (1994), a discussão sobre representação social traz em si a ideia basilar das mesmas como um construto

\footnotetext{
${ }^{3}$ Baladeli poderia ter utilizado um outro termo para expressar tal ideia, por exemplo, "vilipendiar". Por ser uma citação direta, não é possível modificar o texto para que a conotação equivocada do termo "denegrir" seja eliminada.
} 
coletivo de dado grupo social. Representações sociais são formadas através de diversas interações sociais ao longo da história, incluindo as relações de poder, e elas passam a ser "realidades parcialmente autônomas [...] que têm o poder de atrair-se, repelir-se, de formar entre si sínteses de naturezas diversas" (DURKHEIM, 1994, p. 50). O que Durkheim classificou como natureza semi-autônoma é uma descrição do tipo de relação que tal representação tem com o indivíduo. Para ele, as representações não eram nunca a criação de um único membro da sociedade, e sempre o resultado do que ele chamava de "consciência coletiva" (DURKHEIM, 2010, p. 81). O aluno, portanto, não terá outra alternativa ao entrar em contato com a língua que lhe é ensinada do que reagir à mesma de acordo com as representações que tem de si e do que é seu.

Uma outra forma de se trazer as minorias estereotipadas, não somente no livro didático, mas também em filmes, programas de televisão, filmes e animações é lançando-se mão do tokenismo, ou minoria de token, que consiste em utilizar uma peça icônica em um contexto homogeneizado para criar a falsa aparência de igualdade. Assim, um único personagem negro, pode ser inserido em um contexto onde todos os outros personagens são brancos para preencher uma lacuna e dar a impressão de que se está representando a todos. Acerca dessas minorias, Georg Simmel (1950, p. 23) diz:

Proporções, ou seja, números relativos de pessoas cultural e socialmente diferentes em um grupo, são vistas como críticas na construção das dinâmicas de interação. Grupos 'desequilibrados' contém uma grande predominância de um tipo (os "dominantes" numéricos) com relação a outro (os 'tokens' raros).

O token, longe de representar a diversidade, acaba por destacar a diferença. O tokenismo isola um integrante da sociedade e faz dele exótico, diferente. Assim como o token não deve ser utilizado como fonte de curiosidade, tampouco deve a cultura. Como foi discutido anteriormente, a cultura deve vir marcada pela comunicação, ela deve ser o motivo pelo qual se estuda a língua. A língua sem cultura é um exercício mecânico e vazio de significado. Tampouco faz sentido estudarmos a cultura como curiosidade. Mesmo porque a própria palavra "curiosidade" é revestida de significado e faz alusão ao diferente, ao estranho. A esse respeito, Almeida Filho (2011, p. 107) expressa: 
A curiosidade cultural não raramente se apresenta como traço de exotismo, podendo resvalar para o estereótipo e daí para o preconceito, ficando longe dos valores da tolerância e/ou da compreensão, ambos potencialmente capazes de propiciar ações mais profundas de integração.

Ao introduzirmos a cultura do outro como curiosa, exótica, diferente, reforçamos o discurso de desigualdade e impedimos que o aluno tome para si a cultura do outro e interaja com ela para gerar comunicação significativa. "Evidentemente, possuir competência sociocultural não significa ter conhecimento dos estereótipos que permeiam determinada comunidade, pois, eles pouca utilidade comunicativa possuem" (FERNÁNDEZ, 2002, p. 40).

Em suma, é necessário pensar sobre cultura através da cultura. A cultura não pode ser tratada como um objeto de estudo isolado. Cultura é o sopro de vida que anima os povos. É através dela que somos e que nos comunicamos. Não existe razão para trazermos a cultura para a sala de aula como apêndice da gramática ou do vocabulário. Ensinar uma língua a partir de sua estrutura é ensinar um conjunto de regras vazias, mecânicas, com as quais os alunos não criam vínculo algum. Por outro lado, consumir a cultura pré-moldada e estereotipada que nos é vendida como diversidade cultural é negar aos nossos alunos a chance de experimentar, de se relacionar com o mundo, de se expressar na sua própria cultura e de fazer parte da cultura do outro. A troca é fundamental na construção de saberes. Privar os alunos dessa troca é tirar deles a chance de se tornarem agentes de sua própria aprendizagem.

No capítulo seguinte, analiso os dois primeiros volumes da coleção de inglês para adolescentes Time Zones. Busco, aliar as teorias apresentadas até o momento para embasar as considerações que teço acerca da caracterização do Brasil e da personagem brasileira, Maya, ao longo desses dois primeiros volumes. Após descrever o material, parto para os textos que se referem ao Brasil e para as instâncias em que Maya fala sobre o Brasil. As demais interações da adolescente que não incluem o Brasil ou manifestações da cultura brasileira não foram abordadas no presente trabalho. 


\section{REFERENCIAL METODOLÓGICO}

\subsection{Introdução}

Este capítulo apresenta o referencial metodológico deste trabalho. Trata-se de um estudo de caso qualitativo-interpretativista, enquadrando-se na modalidade análise documental. Classifico minha pesquisa como estudo de caso por ter me proposto a analisar um evento específico (FREEBODY, 2003, p. 81) dentro do escopo do ensino de língua estrangeira. Tal evento, no caso uma série de livros didáticos, é abordado de maneira interpretativista. Ou seja, percebo, em sintonia com Moita Lopes (1994, passim) e Schwandt (2006, passim), que todo conhecimento é resultado tanto de interpretação pessoal quanto de interação social. Finalmente, sendo o objeto de estudo um material original e não havendo até o presente outras discussões sobre esse material aqui avaliado, meu trabalho é qualificado como análise documental. Na presente dissertação, analiso os quatro volumes que compõem a coleção de livros didáticos de inglês para adolescentes "Time Zones" da editora Cengage Learning.

Nas etapas que antecederam a análise do material, fiz a revisão bibliográfica de temas como: cultura, aquisição de língua, estereótipos culturais, inglês global, imperialismo linguístico e materiais didáticos no ensino/aprendizagem de língua estrangeira. Estes temas e suas interações/correlações formam o panorama teórico contra o qual acredito que materiais didáticos de língua inglesa devam ser avaliados. O que apresentei e discuti sobre esses macro-temas alicerça as análises presentes na quarta parte dessa dissertação.

Procurei manter a revisão de literatura tão ampla e significativa quanto possível. As fontes mais diversas foram consultadas, incluindo, além da consulta a livros, revistas e periódicos, consultas ao banco de dados da biblioteca do congresso americano e participação em sessões de exposição do material aqui discutido pela editora. Os dados gerados dessa ampla coleta foram submetidos a uma análise metodologicamente identificada com a triangulação de autores. A intenção da 
triangulação é diminuir a probabilidade de erros de interpretação ou de interpretações tendenciosas através de redundância nas fontes de dados (utilização de fontes diversas quando possível), assim como o uso de referências diversas a fim de tornar o sentido daquilo que é observado mais claro e transparente (FLICK, 1992 In: STAKE In: DENZIN; LINCOLN, 1994, p. 241).

A fim de justificar de maneira mais sólida as escolhas metodológicas por mim realizadas, discorro brevemente sobre a natureza desta pesquisa e os conceitos de estudo de caso e de análise documental.

\subsection{Natureza da pesquisa}

Conforme mencionado, a natureza dessa pesquisa é qualitativa, sendo essa a forma de pesquisa que julgo mais adequada para lidar com a análise de um material didático, especialmente no que tange ao olhar específico que decidi lançar sobre o mesmo. Além disso, entendo que, somente uma análise qualitativa daria conta dos dados obtidos e das questões levantadas por essa pesquisa.

\footnotetext{
A pesquisa qualitativa envolve o estudo do uso e a coleta de uma variedade de materiais empíricos - estudo de caso; experiência pessoal; introspecção; história de vida; entrevista; artefatos; textos e produções culturais; textos observacionais, históricos, interativos e visuais - que descrevem momentos e significados rotineiros e problemáticos na vida dos indivíduos. Portanto, os pesquisadores dessa área utilizam uma ampla variedade de práticas interpretativas interligadas, na esperança de sempre conseguirem compreender melhor 0 assunto que está ao seu alcance (DENZIN; LINCOLN, 2006, p. 17).
}

Não só compartilho dessa esperança de uma compreensão mais efetiva do que me dispus a discutir, também acredito que um olhar qualitativo pode gerar "relatos mais ricos e nuanças mais delicadas da ação humana" (GERGEN; GERGEN, 2006, p. 68). Isso quer dizer que dados de natureza diversa e questionamentos que podem levar a variadas direções tornam-se aparentes. A reflexão sobre aquilo que se estuda em uma pesquisa dessa natureza consistirá muitas vezes em achar significado ou mesmo narrativa no que o pesquisador descobre. 
A diversidade de práticas metodológicas da pesquisa qualitativa pode ser vista como soft Science, jornalismo, etnografia, bricolagem, confecção de colchas e montagem. O pesquisador, por sua vez, talvez seja visto como um bricoleur, um indivíduo que confecciona colchas, ou, como na produção de filmes, uma pessoa que reúne imagens transformando-as em montagens (DENZIN; LINCOLN, 2006, p. 18).

Desse ponto de vista, o que seria mais adequado para analisar práticas educacionais e materiais didáticos que um mosaico de dados? Cada um com sua função individual e, ao mesmo tempo, partes fundamentais na composição de um produto final. A pesquisa qualitativa é a interpretação e análise de dados que estão em constante movimento. De variáveis passíveis de serem refutadas tão logo quanto os resultados são publicados. Nesse sentido, pode sim ser uma ciência soft, branda, mas não por ser de menor valia ou mais simplista, mas sim por reinventar-se a cada nova publicação.

\subsection{Estudo de caso}

Escolhi trabalhar com estudo de caso por ele trazer em si a flexibilidade, que entendo ser necessária ao analisar questões ligadas à educação, se é parte dos meus anseios acadêmicos conseguir insights que sejam válidos e inovadores. Críticos podem discutir a relevância de uma pesquisa realizada a partir de um objeto tão limitado. Contudo, o resultado de se estudar da maneira mais específica e detalhista possível um único objeto conduz a percepções e discussões que perpassam muito mais do que aquele objeto. Outrossim, são relevantes para todo o contexto no qual ele encontra-se inserido. O debate desse evento único - neste caso, uma série de livros didáticos - levanta, fatalmente, questionamentos importantes não só quanto ao projeto de materiais didáticos, mas também quanto ao ensino da língua inglesa e à educação em geral. Sendo esse, em última instância, o objetivo de qualquer estudo de caso:

O objetivo do estudo de caso, em sua forma mais geral, é propor um questionamento a partir do qual tanto pesquisadores quanto educadores possam refletir sobre instâncias específicas da prática educacional (FREEBODY, 2003, p. 81).

Tal objetivo dos estudos de caso em geral foi plenamente atingido nessa pesquisa, conforme a análise apresentada na seção subsequente. A partir do que 
estudei e interpretei sobre a série "Time Zones", questões muito mais amplas vêm à tona. De que maneira os livros de EFL podem melhor contemplar a diversidade? Como os materiais didáticos de EFL podem promover o contato com outras culturas e conexões significativas? Quais interesses mercadológicos e outras forças dão forma aos materiais didáticos que existem hoje? Contudo, há diversas razões para que um pesquisador decida estudar um dado objeto em uma pesquisa:

\begin{abstract}
Pesquisadores diferentes tem propósitos diferentes ao estudar um caso. A fim de manter essas diferenças em mente, considero útil identificar três tipos de estudo. No que podemos chamar de estudo de caso intrínseco, o estudo acontece porque se quer melhor compreensão deste caso em particular. $O$ estudo não é levado a cabo primariamente pelo caso representar outros casos ou por ele ilustrar uma tendência ou problema específico, mas porque, em toda sua especificidade e trivialidade, este caso é interessante por si próprio (STAKE In: DENZIN; LINCOLN, 1994, p. 247).
\end{abstract}

Há inúmeros de fatores que, para mim, tornam esse caso "interessante por si só". O principal deles é o fato de que este é um material que, a priori, se propõe a discutir cultura e diversidade. E o faz tanto apresentando material diversificado (áudio, vídeo, textos) sobre diferentes países do mundo, como com personagens da mesma faixa etária do seu público alvo de diversas etnias e nacionalidades. Inclusive uma personagem brasileira. A seleção e apresentação desse material, bem como a construção dessa personagem constituem fonte de inegável interesse.

\title{
3.4. Análise documental
}

Uma vez selecionado o material que consistiria em meu objeto de estudo, a classificação deste mesmo estudo em análise documental foi uma consequência natural. Comparando análise documental à pesquisa bibliográfica, Gil (2002, p. 45) afirma que:

A pesquisa documental assemelha-se muito à pesquisa bibliográfica. A diferença essencial entre ambas está na natureza das fontes. Enquanto a pesquisa bibliográfica se utiliza fundamentalmente das contribuições dos diversos autores sobre determinado assunto, a pesquisa documental valese de materiais que não recebem ainda um tratamento analítico, ou que ainda podem ser reelaborados de acordo com os objetos da pesquisa.

Pela publicação relativamente recente do material, estando o mesmo ainda em fase de absorção pelo mercado, não foi encontrado nenhum estudo acadêmico 
sobre o mesmo. Além disso, havia de minha parte um interesse genuíno em analisar o material em si, pela proposta do mesmo tocar em temas que me são caros como cultura.

\footnotetext{
O desenvolvimento da pesquisa documental segue os mesmos passos da pesquisa bibliográfica. Apenas cabe considerar que, enquanto na pesquisa bibliográfica as fontes são constituídas sobretudo por material impresso localizado nas bibliotecas, na pesquisa documental, as fontes são muito mais diversificadas e dispersas (GIL, 2002, p. 46).
}

Gil (2002) apresenta o baixo custo, a estabilidade dos dados e a ausência de contato com o sujeito como vantagens da pesquisa documental. $\mathrm{O}$ autor, no entanto, pondera que há limitações nesta modalidade de pesquisa, dentre elas, a não representatividade e a subjetividade dos documentos; limitações essas que podem ser contornadas se houver rigor na escolha dos documentos e análise cuidadosa dos mesmos.

O material a ser analisado, a coleção Times Zones, foi escolhido por algumas razões. Primeiramente, é uma publicação recente. Assim sendo, reflete tendências atuais no material didático desenvolvido para e utilizado no ensino de língua inglesa para adolescentes brasileiros. Além disso, a coleção é uma publicação da Cengage Learning, uma multinacional de educação com publicações voltadas para os mais diversos contextos de ensino-aprendizagem. Cengage é uma participante relevante no cenário educacional, por isso, tanto reflete como influencia tendências no material desenvolvido no mundo. Selecionar o material de uma editora de grande influência foi um dos critérios adotados.

Finalmente, essa série específica é a primeira parceria da National Geographic com uma empresa de educação a fim de que materiais para o ensino de língua inglesa sejam desenvolvidos a partir do vasto acervo documental da National Geographic. A sociedade formada pela National Geographic tem catalogado não só o mundo natural, mas as mais diversas expressões humanas no planeta. Como Rob Jenkins (2014), autor da série para adultos que se segue a Time Zones, afirmou recentemente: "National Geographic é pura cultura". Por essas razões, foi escolhida essa série de livros, pois é potencialmente representativa de tendências atuais na produção de material didático e, a priori, traz consigo um elemento de preocupação com a cultura. 
Tal elemento foi citado pelo diretor de projetos para a América Latina da National Geographic Learning, Jair Félix (2014), quando o questionei sobre como a cultura estava inserida no referido livro didático. De acordo com ele, eles decidiram ampliar seu mercado com a publicação de material didático com conteúdo da National Geographic no mundo inteiro, e descobriram um empecilho. Novamente de acordo com Félix, ciências, história e outras matérias são ensinadas de maneiras diferentes ao redor do mundo, por causa da necessidade de regionalização do conteúdo. A única matéria ensinada mais ou menos da mesma maneira era inglês. "Não importa onde você esteja, você tem os mesmos tópicos para cobrir quando se trata de ensinar inglês" (FÉLIX, 2014). Ao reconhecer a homogeneização do ensino, ele implicitamente posiciona o material Time Zones como algo diferente, ao mesmo tempo que admite o maior potencial comercial de materiais homogeneizados que atendam a vários mercados simultaneamente.

As escolhas metodológicas certamente afetarão de maneira profunda o resultado final de qualquer estudo. Por isso, fez-se necessária a exposição dos caminhos metodológicos apresentada nesse capítulo. Com o referencial teórico e a metodologia consolidados, a análise de dados que agora a esses se segue tornarse-á muito mais significativa. 


\section{APRESENTAÇÃO E ANÁLISE DE DADOS}

Iniciarei as análises fazendo uma caracterização dos livros nos quais os dados foram coletados. Segundo a descrição contida no material do professor:

Time Zones é uma série de quatro níveis e quatro habilidades que combina uma abordagem comunicativa de ensino de inglês com o rico conteúdo da National Geographic, desenvolvido para ser engajante para todos os jovens aprendizes, de pré-adolescentes a jovens adultos (COLLINS; MAPLES, 2010a, p. vi).

Cada livro é dividido em quatro áreas de conteúdo: Pessoas e Lugares; O Mundo Natural; História e Cultura; Ciência e Educação. Cada uma dessas áreas é apresentada por um "expert", um dos quatro jovens personagens, dentre eles uma brasileira, chamada Maya. Os livros são distribuídos na Austrália, Brasil, Japão, Coréia, México, Singapura, Espanha, Reino Unido e Estados Unidos.

Como princípios norteadores, o material traz: o inglês para comunicação internacional, o cuidado com o planeta, a motivação dos alunos através de conteúdo autêntico, e a interação com novas tecnologias. Collins e Maples (2010a) declaram que o livro foi pensado de modo a reconhecer o papel da língua inglesa como língua franca e valorizar o uso da língua para a comunicação internacional. Dentre esses, gostaria de destacar o compromisso com o uso de conteúdo autêntico:

É também um princípio fundamental do Time Zones que o conteúdo autêntico, do mundo real, é mais motivador, mais relevante e mais respeitoso com os estudantes do que o conteúdo que é não autêntico ou artificial (COLLINS; MAPLES, 2010a, p. vii).

$\mathrm{Na}$ introdução do livro do aluno, temos a caracterização dos quatro personagens: Stig Anderson, de Estocolmo, na Suécia, um viajante do mundo especializado em pessoas e lugares; Ming Chen, de Shanghai, na China, especialista em plantas e animais; Nadine Barnard, de Cape Town, na África do Sul, presente nas seções de ciência e educação; e Maya Santos, do Rio de Janeiro, no Brasil, especialista em história e cultura. Para fins da presente análise, iremos nos 
ater à caracterização da personagem Maya Santos e aos textos que falam sobre o Brasil. Textos sobre outros temas serão usados, quando oportuno, somente para que se trace um paralelo com os textos sobre o Brasil.

Iniciaremos as análises pelo primeiro volume da coleção. O primeiro volume, beginner, é de nível pré A1 (pré-iniciante) no Quadro Comum Europeu de referência para Línguas. A Figura 1 mostra os níveis estabelecidos como padrão internacional para avaliarmos a competência linguística de uma pessoa, sendo eles A1 (iniciante) e C2 (proficiente). Os volumes da coleção compreendem do nível pré A1 até o nível A2/B1, a transição entre o nível pré-intermediário e o nível intermediário.

\section{Cambridge English}

A range of exams to meet different needs

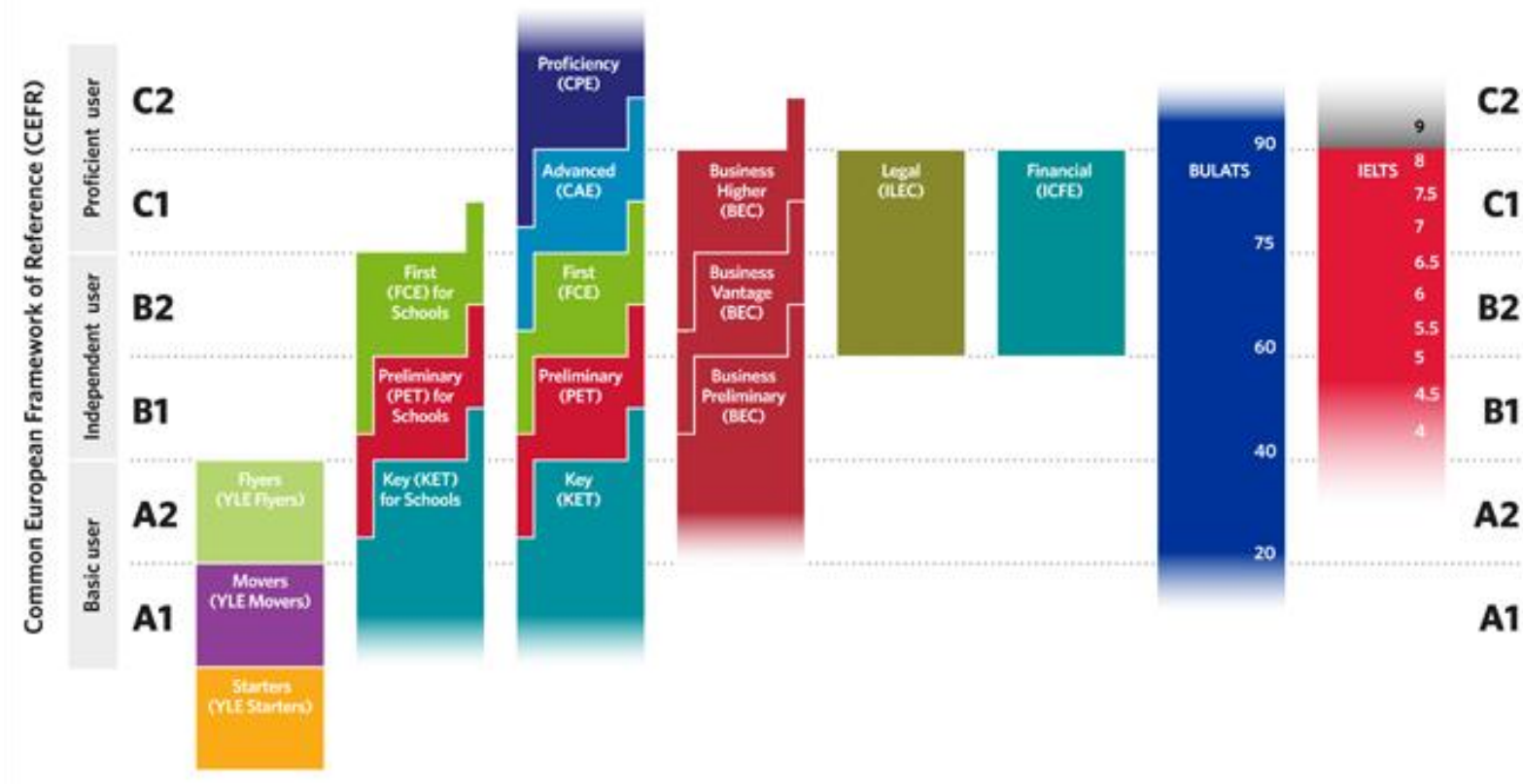

Figura 2 - Quadro comum europeu de referência para línguas.

Fonte: Cambridge English (2015).

Na página de apresentação, o livro traz o que se segue. 


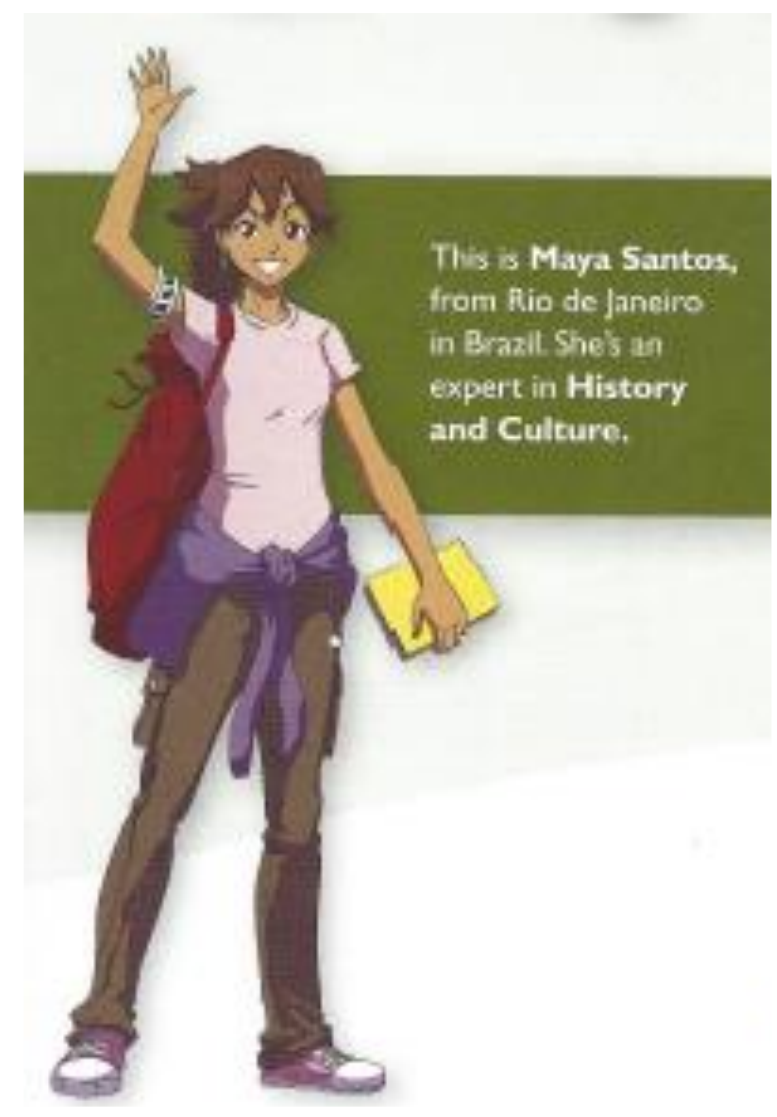

Figura 3 - Página de apresentação.

Fonte: Collins e Maples (2010a).

A personagem é uma adolescente, de pele morena, cabelos e olhos castanhos em conformidade com características físicas comuns para a população brasileira. Suas roupas são condizentes com as vestimentas usadas por adolescentes desta faixa etária, com exceção talvez do acessório de referência indígena usado no braço direito. Um dos aspectos que chamam atenção é o nome escolhido para a personagem, Maya Santos, um prenome bastante incomum entre as garotas brasileiras. O sobrenome Santos é bastante comum e representativo do Brasil. A personagem é original do Rio de Janeiro, uma cidade icônica e facilmente reconhecida por estrangeiros. 
Na próxima figura, as informações são expandidas para incluir seu esporte e time favoritos, previsivelmente futebol e Flamengo. Aqui se perdeu a oportunidade de mencionar outras cidades ou esportes. Embora o Brasil tenha um território vasto e rico, o Rio de Janeiro e Salvador, em uma instância apenas, são as únicas cidades brasileiras citadas nos quatro volumes da coleção.

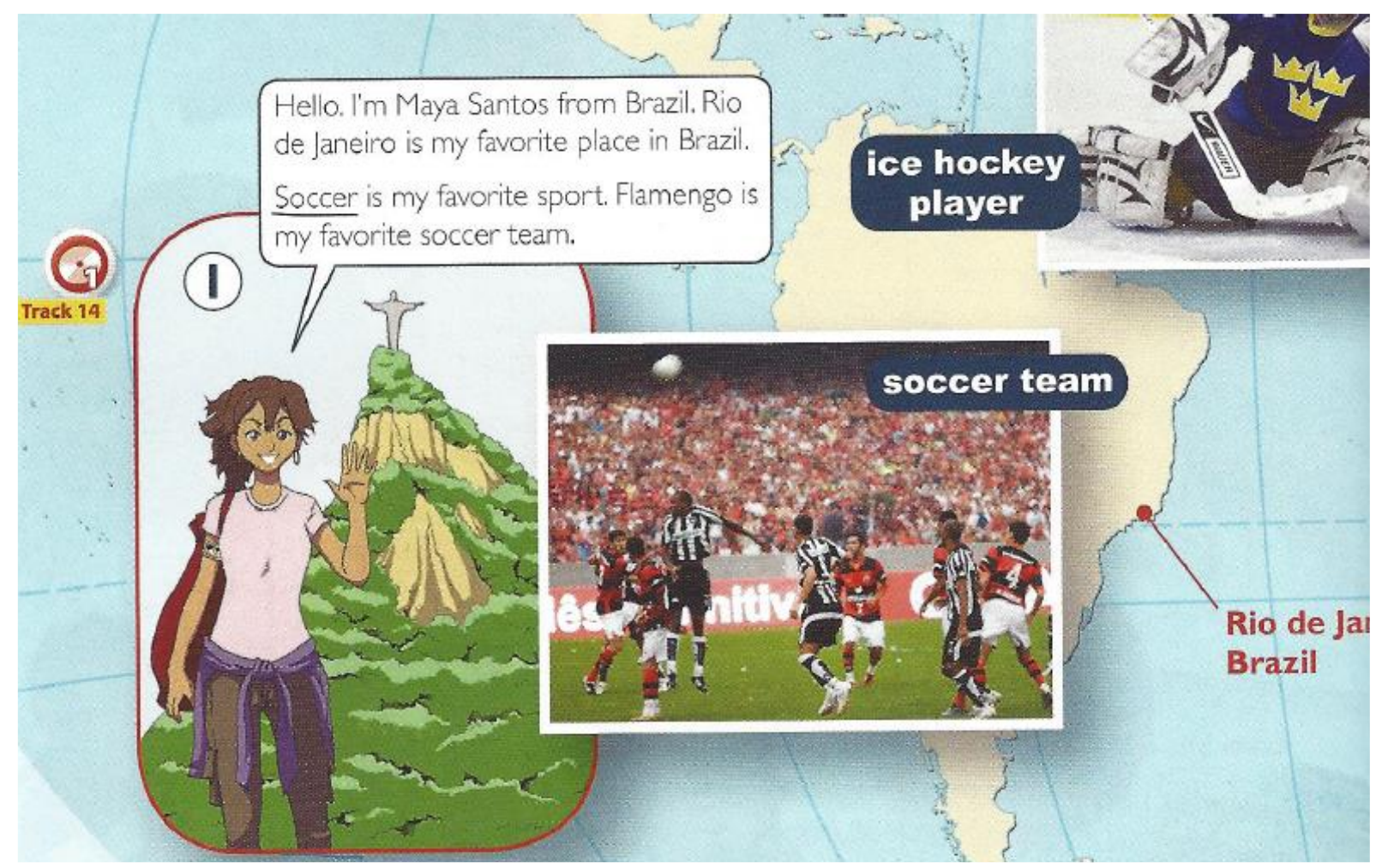

Figura 4 - Caracterização da personagem.

Fonte: Collins e Maples (2010a).

Ao fundo da imagem, vemos o Cristo Redentor e, no destaque, um jogo do Flamengo. Deste modo, passo a passo foi construída a imagem do brasileiro como sendo carioca, amante de futebol, torcedor do Flamengo. Cabe destacar que a cidade favorita da adolescente é também a sua própria cidade de origem. A construção não é imprecisa, este personagem é bastante comum no Brasil, no entanto, ele simplifica e reduz duzentos milhões de pessoas a uma única figura. Acerca destas simplificações, Brown (2007, p. 190-191) afirma que:

sob as lentes de nossa própria visão cultural do mundo, nós frequentemente retratamos outras culturas de maneira simplista, agrupando diferenças culturais em categorias exageradas e, então vemos todas as pessoas de uma cultura como possuidoras de traços estereotipados. 
Não se trata de uma imagem falsa ou equivocada, no entanto, ela descarta as outras possibilidades de representação e coloca a todos em uma caixa só, impedindo que a realidade seja percebida a partir de outros pontos de vista culturais. Em um país onde o futebol é um esporte popular, só o time do Flamengo tem relevância? Com a cidade de São Paulo ranqueada entre as dez maiores cidades do mundo, somente o Rio de Janeiro representa o Brasil? De acordo com Brown (2007, p. 191),

o estereótipo pode ser preciso ao retratar o 'típico' membro de uma cultura,
mas ele é impreciso para descrever um indivíduo em particular
simplesmente porque cada pessoa é única e a totalidade das características
de comportamento de uma pessoa não podem ser previstas com precisão
com base em um ponto médio generalizado ao longo de um contínuo de
normas culturais.

Se o material tivesse a cultura como pedra angular, e não como adorno, talvez pudesse incluir um maior número de sujeitos culturais e, consequentemente, enriquecer a troca de experiências entre os alunos dos diversos países nos quais o material é comercializado. Uma solução para isso seria a inclusão de atividades centradas no aluno e não no livro, atividades que permitissem a geração de conteúdo verdadeiramente autêntico, ou seja, partir da experiência dos membros de cada sala de aula.

A figura cinco, integrante da sessão do livro intitulada "Real English" (em português, Inglês Real) serve como apoio para a prática guiada. Após repetir o diálogo, o aluno é convidado a praticar o diálogo substituindo as palavras destacadas por outras que se encaixam no mesmo contexto e não prejudicam a estrutura gramatical da frase. Por ser um livro de nível iniciante, a produção livre seria limitada sem o auxílio do vocabulário oferecido no quadro. Entretanto, penso que poderia soar artificial e vazio de sentido para integrantes de culturas cujas práticas não foram exemplificadas. Mais adiante, falaremos sobre uma atividade na qual os alunos terão a oportunidade de falar sobre o ano novo em suas respectivas culturas também. 


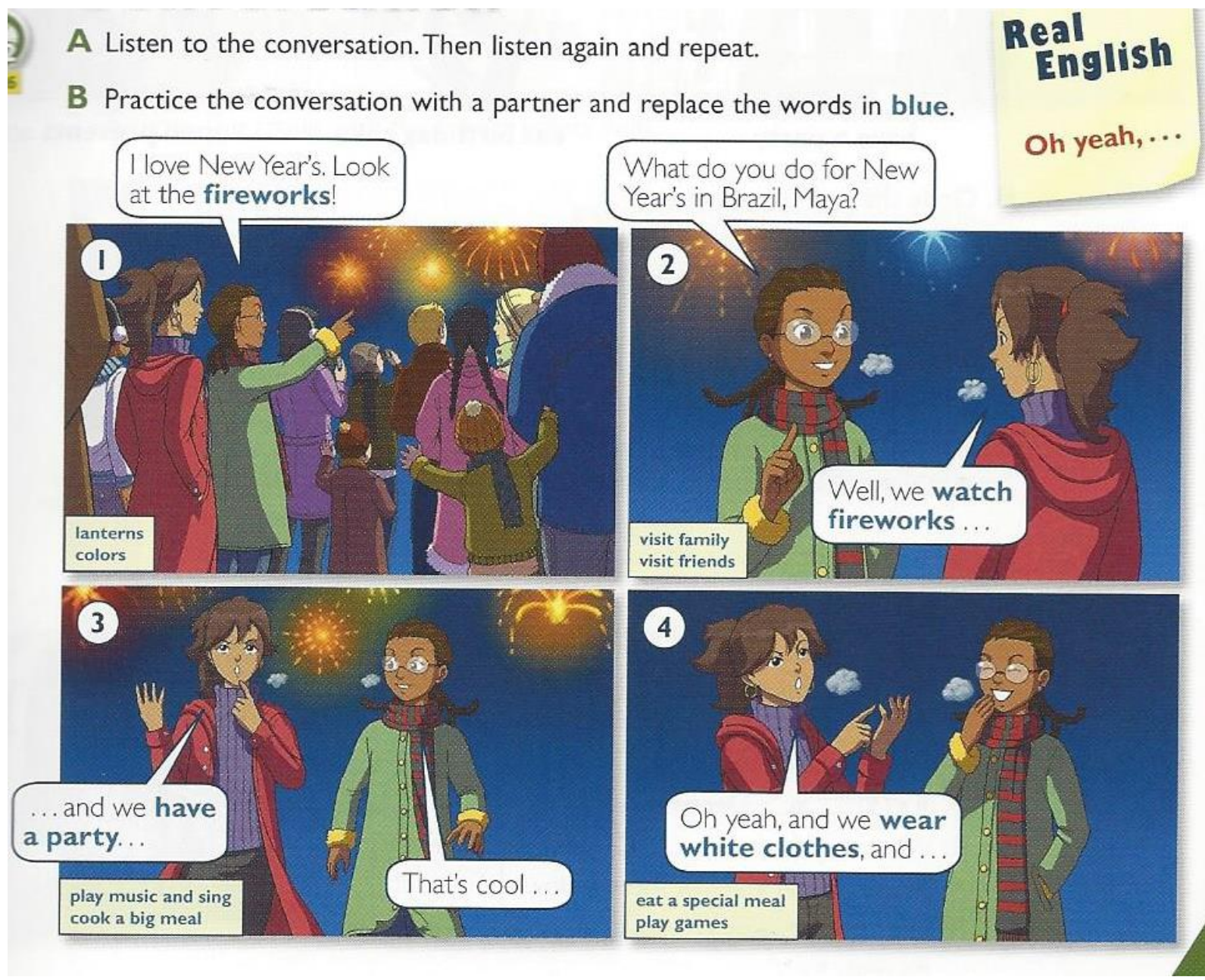

Figura 5 - Real English.

Fonte: Collins e Maples (2010a).

No tocante ao conteúdo, acredito que as atividades listadas aqui e no outro exercício sobre ano novo representam as algumas das atividades realizadas por adolescentes brasileiros no ano novo: ver o show de fogos de artifício, visitar familiares, visitar amigos, ir a uma festa, tocar música e cantar, fazer uma refeição especial, usar roupas brancas, participar de jogos.

Nas notas de conteúdo para o professor, o autor se restringe a definir Divali e o Ano Novo japonês, duas festividades ilustradas nas fotos da página anterior. As anotações são breves e somente situam a festividade geograficamente e mencionam algumas atividades:

Divali, também conhecido como Diwali e Festival das Luzes, é celebrado por cinco dias entre meados de outubro e meados de novembro. Ele tem 
sido um feriado tradicionalmente celebrado na índia, mas tem se espalhado para outros países ao redor do mundo também.

$\mathrm{Na}$ anotação sobre o Ano Novo, pode-se ler:

Ano Novo (shogatsu ou oshogatsu) é o feriado mais importante no Japão. Elementos tradicionais do feriado incluem reunir-se com amigos e familiares, visitar um templo na véspera à meia noite quando os sinos são tocados 108 vezes, e acordar cedo para testemunhar o primeiro nascer do sol de uma novo ano.

As notas auxiliam os professores de outros países para os quais as celebrações são desconhecidas, no entanto, a menos que haja um trabalho paralelo com essas festividades, o material do aluno se limita a ilustrar cada celebração com fotos dos arquivos da National Geographic e a cobrar do aluno que devolva as poucas informações a ele fornecidas nos textos e arquivos de áudio. Os arquivos da National Geographic são, certamente, ricos o suficiente para que se faça um trabalho um pouco mais zeloso de se trazer assuntos de relevância cultural e social para os alunos.

As figuras seis, sete e oito, combinadas, fazem parte de uma atividade de leitura e interpretação sobre o carnaval no Brasil. Na figura seis, é solicitado que os alunos tentem identificar o país no qual o festival representado na figura acontece. As opções são Estados unidos, Brasil e México. As fotos mostram um desfile de escola de samba e os recortes destacam o vocabulário "desfile", "máscara" e "fantasia". Nenhum aprofundamento sobre o tema é proposto pelo livro, já que a atividade seguinte, pede que $o$ aluno leia $o$ texto, fale $o$ que as pessoas fazem no carnaval, sublinhem os verbos e respondam as perguntas de múltipla escolha da página seguinte. Outro recorte de imagem, destacado na figura sete, mostra a localização da cidade do Rio de Janeiro no globo terrestre. 


\section{Reading}

A Look at the title and the pictures. Where is this festival?
a. the United States
b. Brazil
c. Mexico

B What do people do for Carnaval? Read the article and underline the verbs.

C Answer the questions on page 88 .

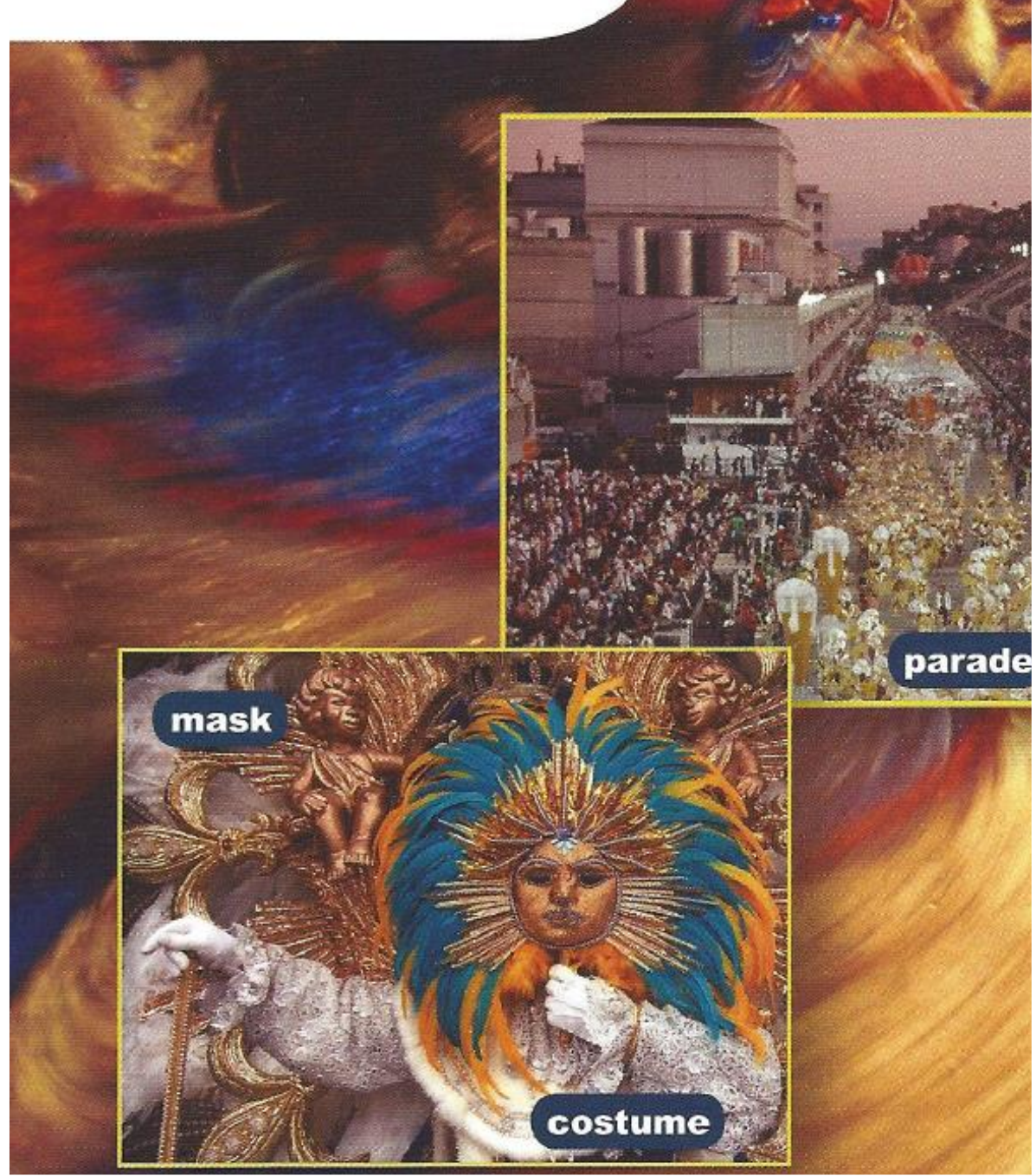

Figura 6 - llustração do texto.

Fonte: Collins e Maples (2010a). 


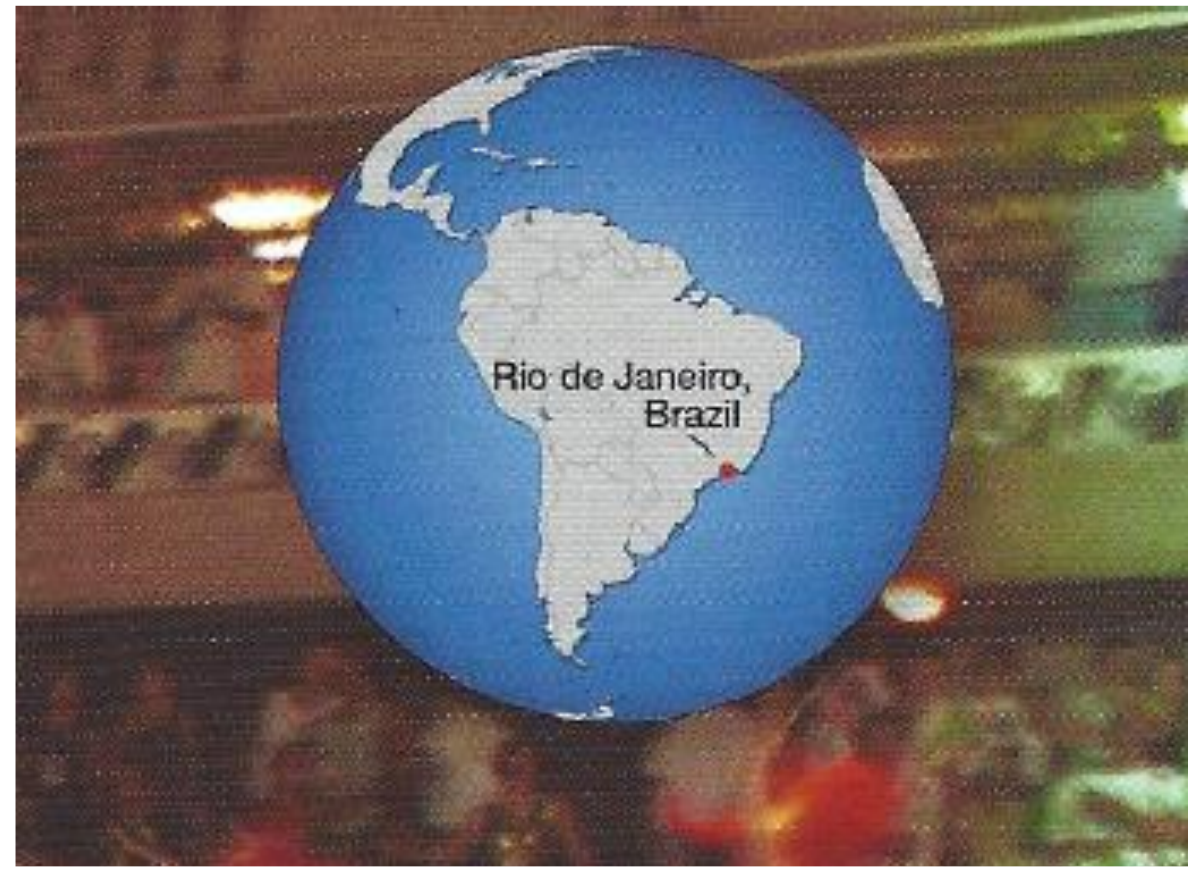

Figura 7 - Globo terrestre.

Fonte: Collins e Maples (2010a).

O texto vem coroar a tríade do estereótipo brasileiro: Rio de Janeiro, futebol e carnaval. Logo no início, o texto estabelece o carnaval como sendo o principal feriado brasileiro e lança mão da primeira generalização: "Todo mundo ama o carnaval! É o feriado número um no Brasil". Certamente, muitas pessoas gostam de carnaval, no entanto, muitas apreciam o feriado mais por causa da pausa no trabalho do que pela tradição ou pelo samba. Em seguida, o texto coloca: "Carnaval é uma festa de quatro dias em fevereiro ou março. É verão no Brasil e o clima é quente". Aqui, não é feita a contextualização histórica da celebração, tampouco se explica do que se trata enquanto manifestação cultural. Outro ponto a ser considerado é o fato de o carnaval ser tratado como um festival homogêneo no mundo inteiro.

Na sequência, o texto afirma: "O carnaval começa com um desfile de samba. Milhares de pessoas assistem ao desfile. Amigos e famílias tocam samba e dançam também". O texto é impreciso ao afirmar que o início do carnaval se dá com o desfile das escolas de samba. Na maior parte do país, o desfile sequer é uma tradição e grande parte dos brasileiros jamais assistiu a um desfile ao vivo no Rio de janeiro, seja pela distância seja pelo alto custo dos ingressos. Novamente, a realidade do Rio de Janeiro é tomada como verdade absoluta para o restante do país. No tocante à música, o artigo diz que famílias e amigos tocam e dançam samba um ritmo que, 
apesar de tradicional, não é regra. As diversas regiões do país celebram o carnaval com ritmos variados como: axé, frevo, marchinhas, afoxé, ciranda, pagode, entre outros.

O terceiro parágrafo afirma: "Durante o carnaval há grandes festas. Bandas tocam música. As pessoas usam fantasias e máscaras maravilhosas. Elas comem churrasco". Apesar de essas atividades acontecerem, não existe como regra uma tradição de se festejar somente desta maneira. O churrasco, apesar de ser uma comida apreciada por brasileiros, não é uma comida de carnaval. Carnaval também não inclui necessariamente fantasias e máscaras. Existe uma origem histórica para a celebração do carnaval, existem manifestações culturais importantes no país que não envolvem o desfile das escolas de samba, existe ainda quem não goste de carnaval e passe o feriado em casa para evitar a multidão.

Para concluir, o autor faz um convite: "Você gosta de música? Você gosta de máscaras e fantasias? Venha para o Brasil para o Carnaval e assista ao desfile". O convite é bastante tendencioso, pois leva a acreditar que os desfiles são de fácil acesso, um fato que em muito se difere da realidade por trás da celebração do carnaval. 


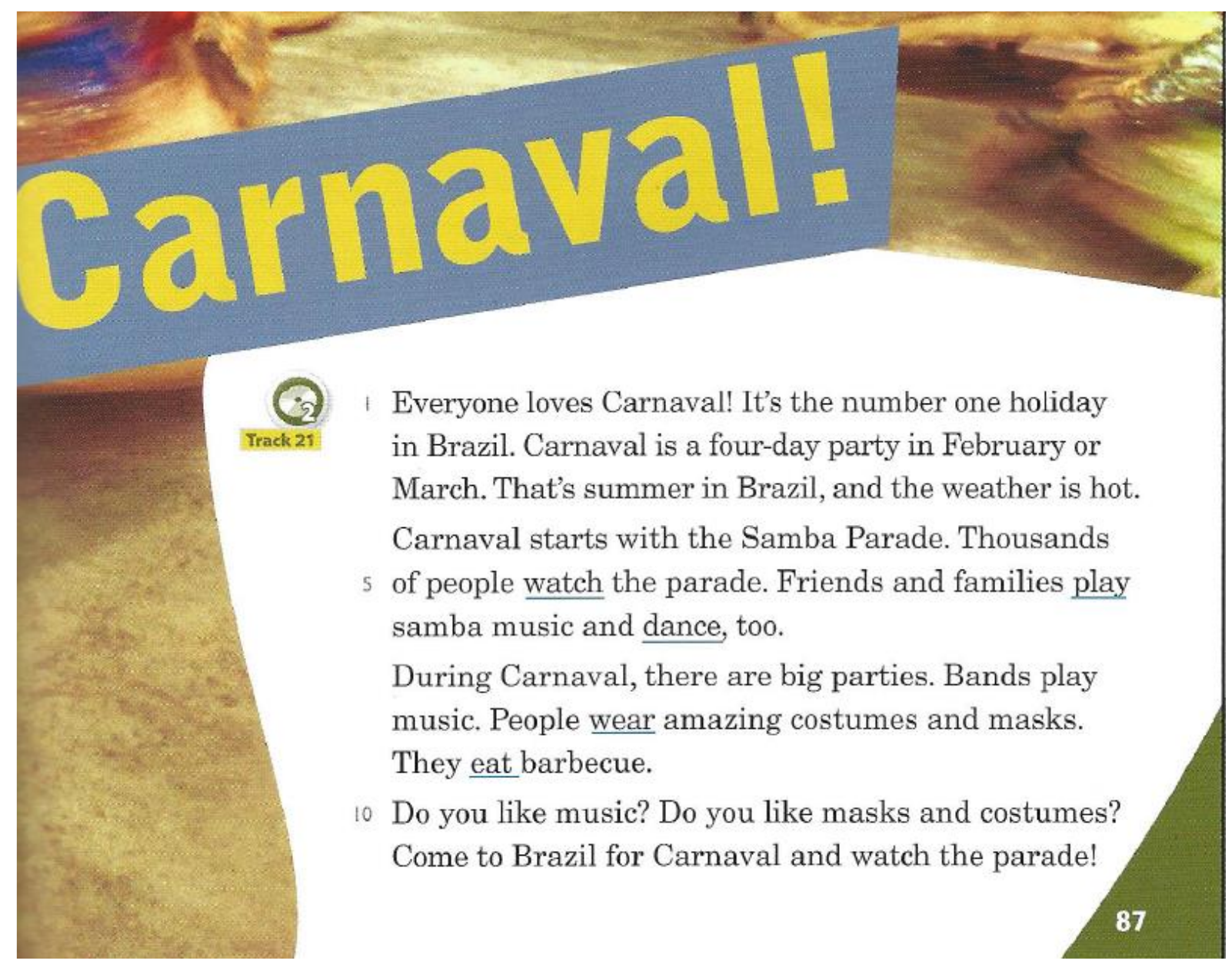

Figura 8 - Texto sobre o carnaval.

Fonte: Collins e Maples (2010a).

Segundo Baladeli (In: FERREIRA, 2014, p. 233):

Os textos veiculados no livro didático de língua inglesa precisam ser explorados como detentores de discursos e, por conseguinte, detentores de ideologias que, quando não problematizadas, podem salientar representações distorcidas das identidades socioculturais brasileiras.

Deste modo, ao reforçar a ideia de que o brasileiro é fã de futebol, ouve samba e mora no Rio, exclui-se um grande número de jovens brasileiros que sequer assistem aos desfiles na televisão e perde-se a oportunidade de problematizar o acesso a essas manifestações culturais. Os grandes desfiles, Rio e São Paulo, ocorrem em áreas isoladas para o grande público e contam com ingressos vendidos a preços elevados, mantendo a população geral à margem dessas celebrações, o que faz delas um item de luxo reservado aos turistas. Nas cidades pequenas, as festas de ruas ou de clubes têm pouca semelhança com as manifestações 
representadas nas fotografias do livro.O carnaval é uma indústria que movimenta comunidades inteiras e é responsável pelo sustento dessas comunidades ao longo do ano. Essa problemática não só faz parte da cultura do carnaval, como da cultura do país. Essas discussões não devem ser deixadas fora da sala de aula, elas enriquecem a aula de língua que, infelizmente, costuma ser guiada pela gramática.

O exercício, que inicialmente pede para que os alunos sublinhem os verbos do texto, não contextualiza esses verbos e não pede para que esses verbos sejam empregados em outros momentos. A atividade é vazia de significado tanto do ponto de vista gramatical, como do ponto de vista de produção de sentido.

A figura nove, traz cinco questões de múltipla escolha a respeito do texto. Todas as perguntas são de resposta direta, e não estimulam a interpretação ou crítica ao conteúdo. Não há também uma atividade que promova a discussão ou a expansão do tópico.

\section{Comprehension}

A Answer the questions about Carnaval.

I. Carnaval in Brazil is in the
a. spring
b. summer
c. winter

2. Carnaval starts with

a. a party

b. fireworks

c. (a parade

3. What does "They" mean in line 9?
a. people
b. fireworks
c. costumes

4. During Carnaval, people

a. eat cake and dance

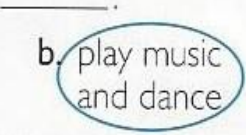

c. play music and open presents

5. During Carnaval, people wear
a. bands
b. costumes
c. lanterns

Figura 9 - Compreensão de texto.

Fonte: Collins e Maples (2010a).

Para fechar a sequência de exercícios com base no carnaval, a figura nove traz um exercício que daria ao aluno a oportunidade de produzir linguagem autêntica a partir de sua vivência cultural e das representações que lhes são familiares. No entanto, ao trazer um quadro restringindo as opções de vocabulário a serem usadas, deixa-se pouco espaço para a produção verdadeiramente original e significativa. Os balões pedem que os alunos elenquem as atividades realizadas durante o carnaval, 
de acordo com o texto, usando as palavras do quadro. Em seguida, ele deve listar as atividades realizadas em seu feriado favorito e comparar ambas celebrações a fim de determinar características comuns de ambas festividades.

B What's your favorite holiday? Write it in the right side of the chart.

Then complete the diagram. Use some of these words.

\begin{tabular}{llll}
\hline $\begin{array}{l}\text { sing } \\
\text { dance }\end{array}$ & have a barbecue & visit family & play music \\
& watch a parade & watch fireworks & play games
\end{tabular} eat a special meal

Carnaval Both holidays Your holiday:

Answers will vary.

Figura 10 - Exercício de produção.

Fonte: Collins e Maples (2010a).

Como as quatro habilidades: leitura, escrita, compreensão auditiva e produção oral são trabalhadas de maneira compartimentada, a última atividade da sequência consiste na produção de um parágrafo sobre o festival favorito do aluno. Aproveitando o tema "carnaval", uma página da web (figura nove) traz um pequeno parágrafo sobre o carnaval na Bolívia. A mesma generalização do texto anterior ocorre ao se deixar de lado a riqueza cultural do carnaval de Oruro: a arte popular, 
as máscaras grotescas, os tecidos, os bordados. Uma breve busca na internet ou uma rápida leitura nas anotações do livro do professor, é o bastante para se perceber que a festividade boliviana que recebeu o título de obra-prima do Patrimônio Histórico Oral e Imaterial da Humanidade não está representada na descrição simplista: desfile, roupas coloridas, música e dança.

Assim como no Brasil há várias formas de se celebrar o carnaval, há vários tipos diferentes de carnaval ao redor do mundo. O autor poderia ter simplesmente escolhido descrever o carnaval de uma das várias cidades brasileiras que o celebram. No entanto, ele usou a celebração realizada no Rio de Janeiro como padrão para todo o país. O título "Carnaval no Rio de Janeiro" teria sido mais adequado para o texto, apesar de estar novamente retratando uma única cidade. Uma sugestão seria fazer um projeto com os alunos para levantar as diversas manifestações de carnaval ao redor do mundo ou o carnaval nas diversas regiões do Brasil. Questões como o acesso às manifestações de carnaval e a indústria carnavalesca como fonte de renda para as comunidades carentes poderiam ser trazidas para enriquecer as discussões de sala de aula.

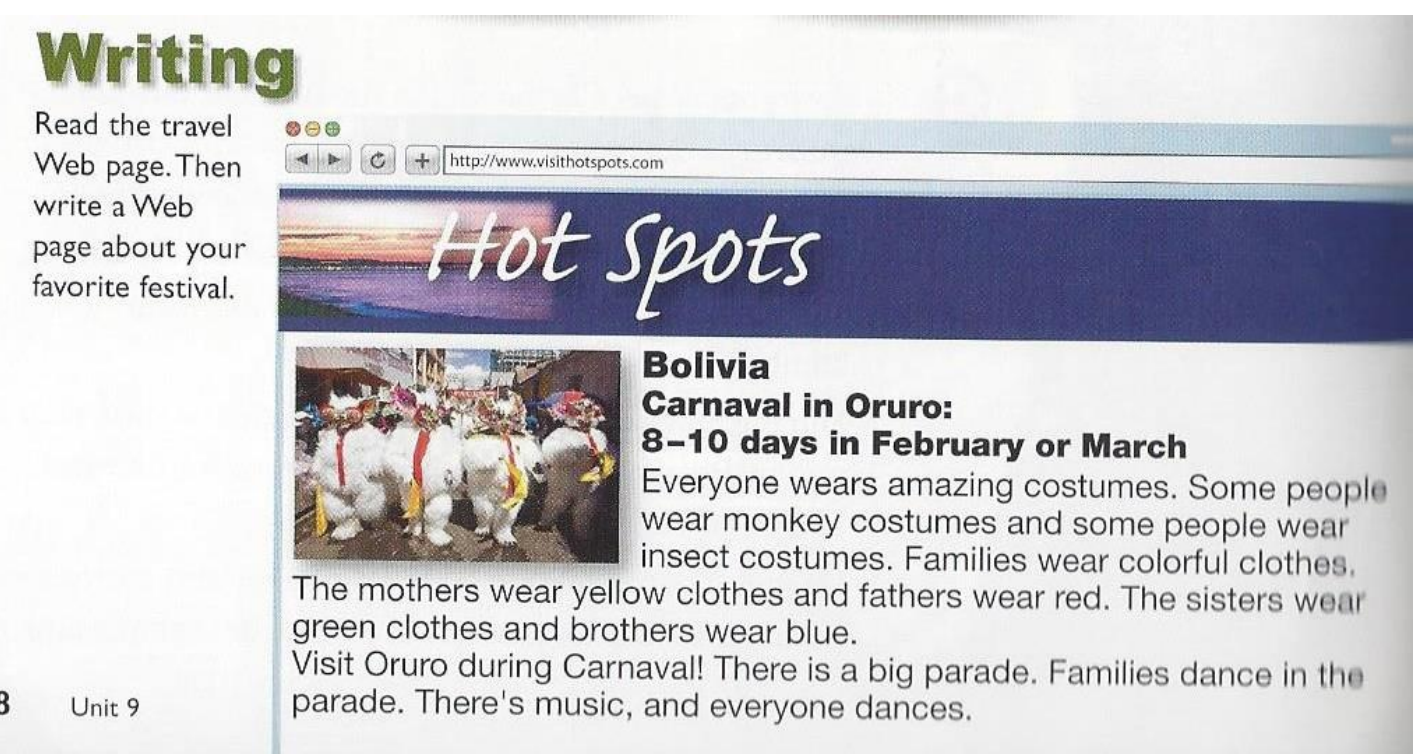

Figura 11 - Redação: carnaval na Bolívia.

Fonte: Collins e Maples (2010a).

Assim como no texto sobre o carnaval brasileiro, o texto sobre o carnaval boliviano vem solto, sem contexto, sem crítica. Kawachi e Lima (In: ROCHA; MACIEL, 2013, p. 96) discutem esse tipo de abordagem no trecho que se segue: 
Algumas metodologias de ensino parecem não permitir abertura o suficiente para a inclusão de conteúdos de preocupação social, de temas abrangentes e transversais, atendo-se ao estudo de estruturas linguísticas em detrimento da formação cidadã do estudante. Além disso, os materiais didáticos adotados geralmente privilegiam concepções superficiais de cultura, ficando ao nível de "curiosidades".

A fala dos autores revela uma preocupação diante dos livros que trazem a cultura como curiosidade. As pinceladas culturais, aparentemente inofensivas, podem ajudar nas vendas para o mercado internacional e camuflam a falta de conteúdo que leve à formação de cidadãos críticos. O ensino de línguas fica isento da responsabilidade social atribuída a outras áreas do conhecimento.

As aulas são "leves" e se restringem ao estudo da língua enquanto estrutura, desvinculada de contexto sociocultural. Os sujeitos dos livros de inglês não têm problemas financeiros, crises de identidade, história, origem. Eles são neutros, genéricos, apolíticos, descontextualizados socialmente, inofensivos. Despimos os personagens dos livros de todas as características que poderiam fazer com que os alunos se identificassem com eles. Criamos um alienígena, um ser estranho, criamos outro em detrimento da criação de um de nós. Assim, ao não se ver representado no outro, o aluno não toma para si esses papéis, não havendo, portanto, a aquisição e troca de cultura que dá significado à comunicação. Continuamos, então, criando barreiras e postulando o ensino de línguas pela língua, vazio de significado.

Para tentar compensar a falta de profundidade do texto, duas notas no livro do professor dão explicações acerca do carnaval. A primeira delas explica quando ocorre o carnaval exatamente: quatro dias antes da quarta-feira de cinzas, início da quaresma (o período de 40 dias de oração, jejum e abstinência antes da páscoa no calendário cristão) e cita a existência de celebrações similares chamadas de Carnaval ou Mardi Gras em países da Europa, nos Estados Unidos e nas Ilhas do Caribe. A explicação não enriquece o texto, tampouco acrescenta conteúdo ao citar existência de celebrações semelhantes em outros países. Cada um desses países comemora o carnaval de uma maneira muito distinta dos outros e, ao colocá-los em pé de igualdade, o autor nega a diversidade cultural.

A segunda nota para o professor diz que o desfile das escolas de samba no Rio começou com as pessoas desfilando e festejando nas ruas com música e dança e evolui para as competições entre as escolas de samba como são conhecidas 
atualmente. A nota explica que as escolas se preparam com muita antecedência e que os temas escolhidos podem remeter a um período histórico ou personalidade do país. Ela ainda faz referência ao samba enredo, aos carros alegóricos e aos ensaios que antecedem a competição em um estádio para setenta mil pessoas.

Enquanto nota de rodapé, no livro do professor, a descrição é bastante completa, no entanto, a cultura e suas nuances ficam resumidas a uma nota de rodapé, a priori invisível ao aluno. Todo o envolvimento das comunidades próximas aos barracões das escolas de samba é deixado de lado. Toda a riqueza por trás da criação das alegorias é descartada. Sem contar que existe a possibilidade de o professor simplesmente deixar todas essas informações extras do manual fora da sala de aula. Se ele assim o fizer, corre-se o risco de o aluno depreender de tudo isso apenas o calor, a música, o desfile, e o churrasco.

Retomo aqui a discussão proposta por Paiva (In: DINIZ; VILELA, 2009, p. 349) quando caracteriza a obra $A$ Tour of Brazil, de Solange Ribeiro de Oliveira:

\begin{abstract}
Da mesma forma que os tropicalistas adotaram a guitarra elétrica sem abandonar o berimbau, Solange adotou a metodologia áudio-visual, fazendo as devidas adaptações temáticas e metodológicas de forma a torná-la adequada à cultura brasileira. A leitura crítica, a interdisciplinaridade com as ciências sociais estão lá na obra A Tour of Brazil, antecipando teorias, desconstruindo as imposições e, principalmente, oferecendo uma outra possibilidade de ensino de inglês que valorizava o local, o nacional, ao mesmo tempo que educava e despertava a consciência dos nossos jovens para as desigualdades sociais.
\end{abstract}

A obra de Solange era muito à frente de seu tempo. Na década de 1980 , Solange já sentia a necessidade de produzir um livro didático que propunha a solução dos problemas que discuto hoje. Com temática essencialmente cultural, $A$ Tour of Brazil promovia discussões acerca de problemas sociais que outros livros simplesmente ignoram. Não é preciso abandonar a cultura de um país para se estudar a língua de outro. Nem é necessário criar personagens idealizados, sem crises, residentes de um mundo imaginário no qual não há desigualdades ou problemas.

Ao contrário de Solange, Time Zones não traz a cultura como essência. A coleção lança mão do recurso discutido anteriormente, o tokenismo, ou minoria de token. No material por ora analisado, percebe-se o uso das minorias de token como regra. O diferente, a minoria, passa a ser a regra. No entanto, no afã de se incluir todas as minorias e de dar a elas status de igualdade, obteve-se o efeito contrário, 
massificaram-se as características que diferenciam cada uma delas e fez-se um grupo homogêneo de minorias para obter maior alcance comercial com o material. Essa massificação causada pelo token é mencionada por Simmel (1950, p. 29) quando ele pontua as três características desses tokens:

\begin{abstract}
visibilidade (tokens capturam uma taxa desproporcional de conscientização), polarização (diferenças entre tokens e dominantes são exageradas), e assimilação (os atributos dos tokens são distorcidos para se encaixarem em generalizações pré-existentes sobre seu tipo social). A visibilidade gera pressões de performance; a polarização leva dominantes a aumentarem as barreiras de seu grupo; e a assimilação leva aos tokens a 'prisão do papel'.
\end{abstract}

A "prisão do papel" pode ser percebida quando não é dada ao brasileiro outra opção de papel social senão o de carioca torcedor do Flamengo amante de samba. O mesmo é feito com os outros personagens e seus respectivos papéis. $\mathrm{Na}$ ânsia de abranger as minorias, exagerou-se na caracterização das mesmas e as reduziu a um único papel, exclui-se assim a possibilidade de que seus pares culturais se identifiquem com esses personagens, ao mesmo tempo que cria-se estereótipos nacionais aos olhos dos alunos de culturas diferentes. Considerando-se que as diferenças e peculiaridades de cada cultura não são problematizadas em sala através das atividades propostas pelo material, os tokens são trazidos como seres exóticos e curiosos.

Outro exemplo desta prática pode ser visto na sessão "Real World" (em português, Mundo Real), quando Maya pergunta sobre as celebrações de ano novo (vide Figura 12, a seguir). A ilustração é grande e colorida, mas a página tem pouco ou nenhum conteúdo cultural, pois falha ao retratar as diferentes manifestações culturais no Ano Novo nos países retratados, tampouco traz um roteiro ou projeto que instigue os alunos a pesquisar e trazer para a sala de aula detalhes sobre essas festividades. A simplificação e generalização se fazem presentes aqui também: "No Brasil, as pessoas assistem a queima de fogos no dia 31. Então, no dia primeiro de janeiro, elas usam roupas brancas e colocam flores no oceano". 


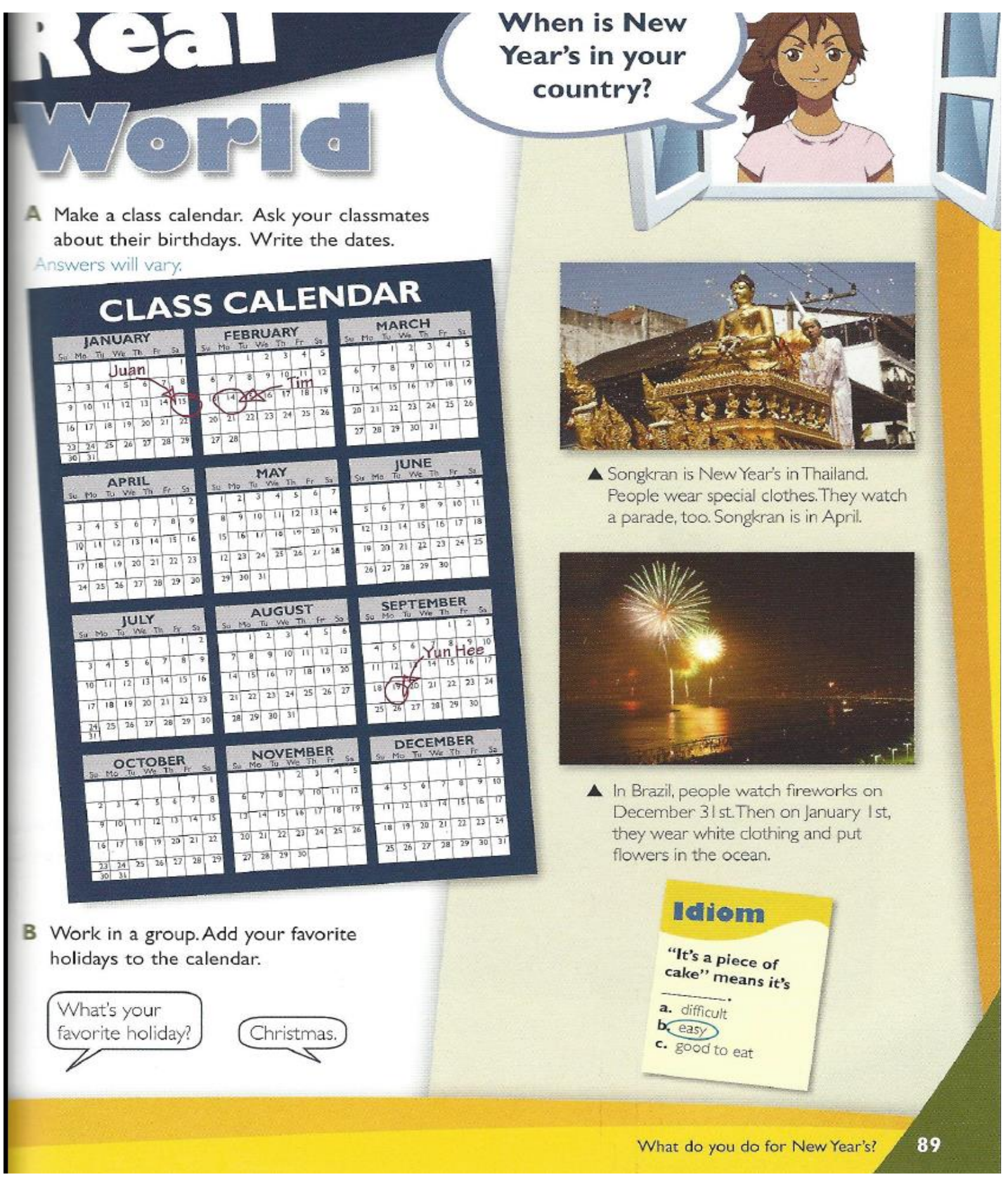

Figura 12 - Real World: Ano Novo.

Fonte: Collins e Maples (2010a).

Há vários aspectos a serem levados em consideração aqui, visto que nem todo o território brasileiro é banhado pelo mar, logo a celebração representada no texto não seria verdadeira para uma significativa parcela da população brasileira. $A$ ilustração é novamente da cidade do Rio de Janeiro e não há contextualização da prática religiosa representada pelo lançamento de flores ao mar. Este ritual consiste 
de uma oferenda a lemanjá, mãe de todos os orixás e protetora das águas. A prática, comum a seguidores de religiões de matriz africana, consiste em se jogar rosas brancas e perfume nas águas do mar, cachoeiras ou rios. A generalização feita neste texto é semelhante àquela discutida anteriormente no texto sobre o carnaval, uma vez que os desfiles das escolas de samba não acontecem em todas as cidades.

$\mathrm{Na}$ breve nota no livro do professor, menciona-se que o dia Primeiro de Janeiro marca o início do ano nos países ocidentais e que é comum que as pessoas façam contagem regressiva para a meia noite. Além disso, explica-se que a palavra "eve", véspera, é usada para marcar o dia que antecede um evento especial ou feriado. Estas observações seriam redundantes para os alunos originários dos países ocidentais adotantes destas práticas e pouco elucidativas para alunos orientais.

Nesta sessão, um trabalho com projetos mais abrangentes sobre as festividades teria o potencial de enriquecer o conteúdo trabalhado até o momento e talvez até relacionar os textos trabalhados com a cultura dos alunos. No entanto, a atividade consiste na identificação das datas dos feriados celebrados pelos alunos, bem como a data do ano novo. O calendário da turma também incluiria os aniversários dos alunos. No canto inferior direito, há um quadro com uma expressão idiomática e alternativas para seu significado. A expressão não tem qualquer relação com as atividades da página ou sequer vem apresentada em uma frase ou diálogo, vindo integrar a lista, relativamente grande, de elementos descontextualizados ao longo do material. Em uma abordagem que priorizasse a cultura, as manifestações culturais familiares aos alunos viriam em primeiro plano e serviriam como ponto de partida para todo o trabalho a ser desenvolvido ao longo unidade. Deste modo, o vocabulário e gramática serviriam de apoio e não de ponto de partida. 
A atividade discutida encerra as menções à cultura brasileira no primeiro volume da coleção e dá o tom para o restante da mesma. Vale aqui lembrar que estou analisando a personagem do Brasil e os textos e atividades sobre sua respectiva cultura. No entanto, todas as características aqui discutidas poderiam facilmente ser estendidas aos outros personagens e suas culturas. Os outros personagens recebem igual tratamento na obra. Como se viu no texto sobre o carnaval na Bolívia, apresentado na sequência do texto sobre o carnaval brasileiro, as informações são inseridas quase que de maneira independente ao longo das lições, uma abordagem dissonante da proposta sugerida no texto de apresentação do livro. Mais adiante, analisarei algumas das interações nas quais Maya aparece sem que o tema seja o Brasil ou nas quais sua nacionalidade e costumes não causam qualquer impacto. A personagem é brasileira, mas poderia pertencer a qualquer outra nacionalidade. Também não há na coleção nenhum exemplo de choque cultural ou desentendimento ocasionado por diferenças culturais. Deste modo, sigo as análises, com as sessões que falam especificamente sobre o Brasil.

Iniciando a análise do segundo volume da coleção, nível A1 no Quadro Comum Europeu, percebemos que o livro é organizado da mesma maneira que 0 primeiro volume, por habilidade, e que essas habilidades se dividem nas seguintes categorias: introdução, conversação gramática (foco na língua), pronúncia, comunicação, leitura, compreensão de texto, escrita e mundo real. Já na primeira unidade, intitulada "What do you like to do?" (O que você gosta de fazer?), a seção de leitura é sobre capoeira, conforme ilustrado nas figuras onze, doze e treze.

A imagem mostra crianças jogando capoeira e, no quadro destaque, uma roda de capoeira com a legenda "Lutadores de capoeira fazem uma grande roda e dançam". No globo terrestre, a cidade de Salvador, Bahia vem destacada. No topo da página esquerda, o exercício pede que se olhe para o título e figuras para se responder às perguntas "Quem são essas pessoas?" e "O que elas estão fazendo?". Os alunos devem discutir a resposta a essas perguntas em pares. Em seguida, pede-se que eles leiam o texto na página seguinte e respondam as perguntas da página dez.

Logo no início do texto há uma referência às crianças em situação de rua: "Em muitos lugares ao redor do mundo, crianças pobres moram nas ruas. Essas crianças das ruas não têm lares ou pais. Elas não vão para a escola e não têm 
hobbies. Suas vidas são muito difíceis". Temos aqui a primeira amostra de texto que se propõe a tratar de assuntos que tenham alguma relevância social. $O$ texto continua: "Em Salvador, Brasil, um grupo especial chamado Projeto Axé ajuda crianças de rua. Ele encontra casas para as crianças e as ajuda a ir à escola e estudar. Ele também as ensina capoeira". A estrutura narrativa do texto não segue o padrão usado em textos de língua inglesa, pois essa estrutura implicaria que o tema capoeira fosse estabelecido na introdução. Ao ler o título e o primeiro parágrafo somente, não é percebida a conexão direta entre os dois. Fica a dúvida com relação ao tema do texto: crianças de rua ou capoeira?

No terceiro parágrafo, o autor faz a definição do que é capoeira:

Capoeira é uma arte marcial, um jogo, e uma dança. As pessoas fazem um grande círculo, cantam e tocam instrumentos. Elas cantam músicas sobre a vida. Dentro do círculo, duas pessoas lutam e dançam. Como no karatê e outras artes marciais, lutadores de capoeira usam roupas brancas.

A partir deste ponto do texto, abandona-se qualquer referência à parte social do projeto Axé estabelecida no início do texto. Os parágrafos seguem de maneira tão independente que, se fossem recortados, poderiam ter sido usados isoladamente sem que jamais soubéssemos que fizessem parte de um contexto maior. A definição de capoeira é bastante coerente com a prática da mesma, mas não fica claro aqui que é uma prática bastante difundida no resto do país e que é praticada por pessoas de todos os estratos sociais. Seria como se o parágrafo que trata das crianças pobres tivesse sido inserido ali para cumprir uma meta de se trazer assuntos relevantes, sem, no entanto, problematizar ou discutir seu conteúdo.

O quarto parágrafo, traz a história de Milton dos Santos, um garoto que pratica capoeira:

Milton dos Santos, um garoto de quinze anos de idade, está aprendendo capoeira. Ele ama capoeira. Ele gosta de dançar e lutar. Esta arte marcial ensina a Milton respeito próprio e como respeitar outras pessoas. A capoeira ajuda as crianças das ruas a terem novas vidas (tradução minha).

Se o livro é para adolescentes, por que não começar com a história do garoto? As chances de identificação ou de sensibilização com a história dele seriam bem maiores. 


\section{Reading}

A Look at the title and the pictures. Who are these people? What are they doing? Tell a partner.

They're teenagers (in Brazil). They're doing capoeira.

$B$ Read the article and check your answers to $A$.

C Answer the questions on page 10.

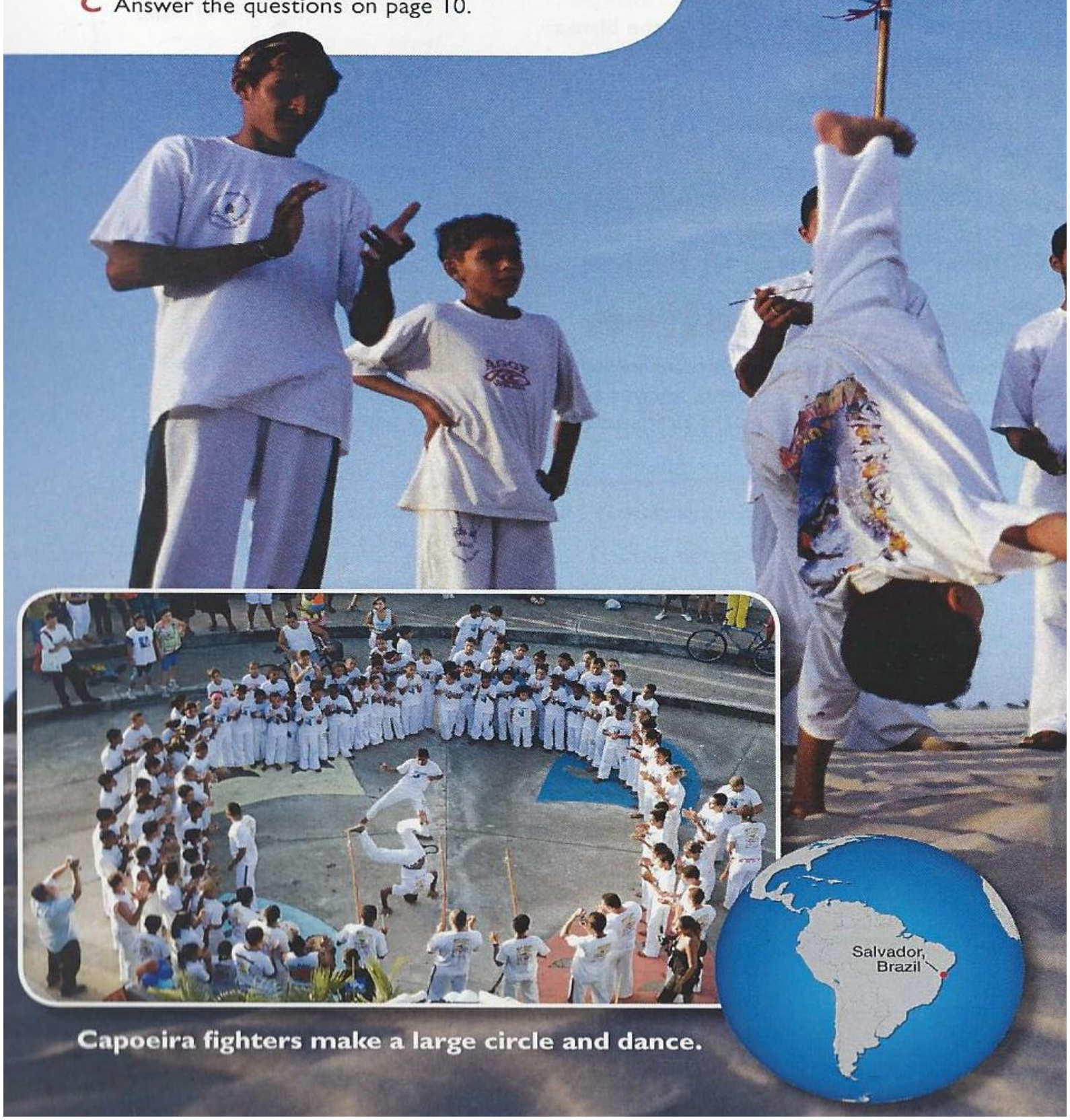

Figura 13 - llustração sobre a capoeira.

Fonte: Collins e Maples (2010b). 


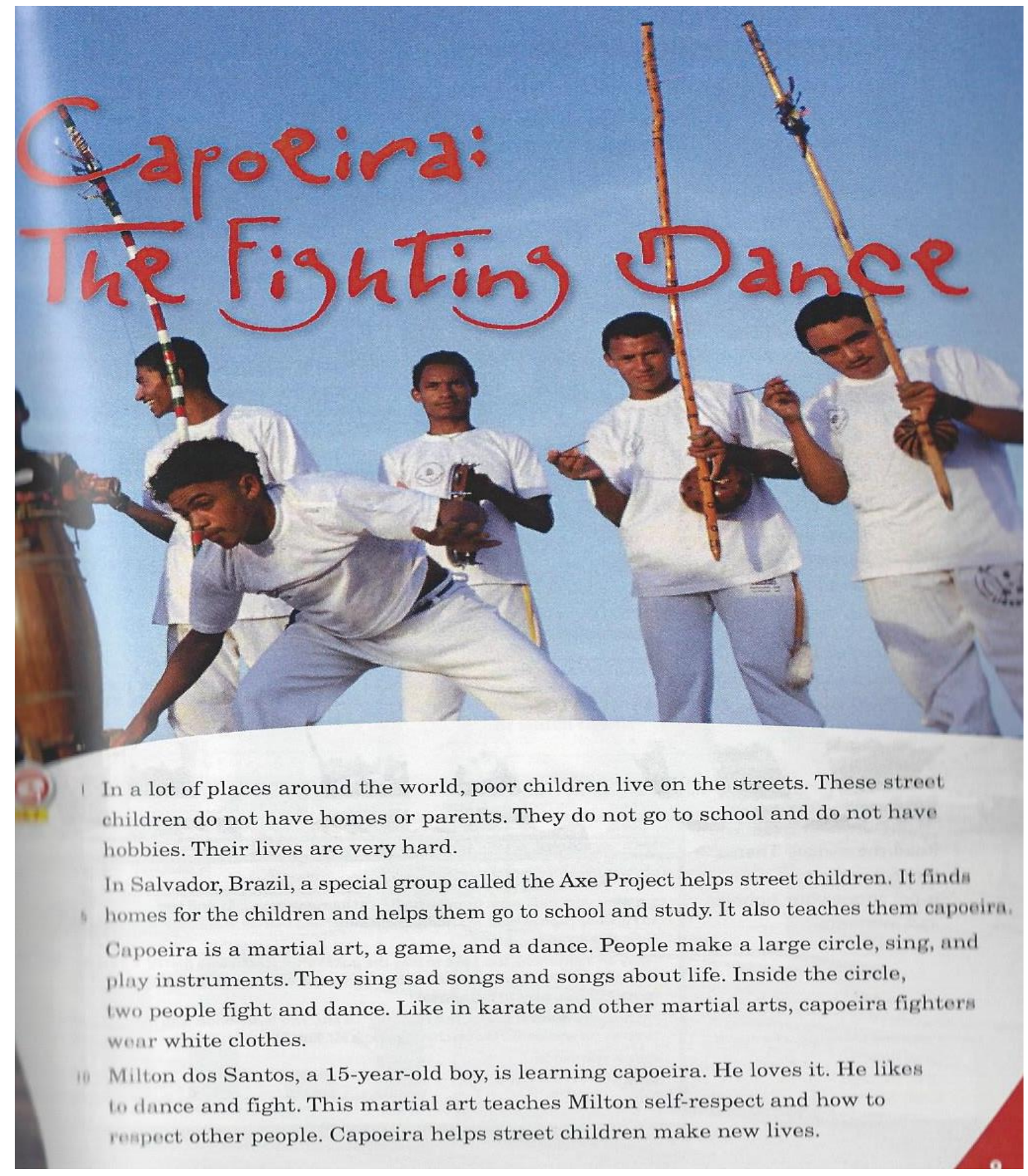

Figura 14 - Texto sobre a capoeira.

Fonte: Collins e Maples (2010b).

Um ponto a ser debatido aqui, e que nos leva novamente ao fato de que os parágrafos não são interligados, é que em momento algum se menciona que Milton é assistido pelo Projeto Axé. Até onde o texto mostra, ele poderia ser qualquer criança. Não há uma ligação entre o projeto e Milton no texto. A última frase vem completamente solta no final do parágrafo que, como conclusão, peca em muitos 
aspectos semânticos e estruturais. O último parágrafo traz informações sobre Milton e termina com uma frase sobre os meninos de rua, quando ele deveria retomar a ideia principal do texto para então chegar a uma conclusão. Da maneira como ele foi construído fica difícil determinar qual é o tema do texto: meninos de rua, capoeira, Projeto Axé, ou Milton dos Santos?

No livro do professor encontramos quatro notas para o professor, três de conteúdo e uma de linguagem. A nota de linguagem esclarece que o termo "street children", crianças de rua, se refere às crianças que moram e trabalham nas ruas. Ela ainda esclarece que essas crianças, que geralmente não têm família ou não se relacionam com suas famílias, moram nas ruas e dormem em caixas de papelão embaixo de pontes, parques, prédios abandonados e outros abrigos improvisados. Caso o problema social fosse o foco do texto, essas informações poderiam vir no texto dos alunos acompanhando atividades que levassem a refletir sobre os problemas sociais percebidos pelos alunos em suas comunidades. No entanto, a informação vem como nota de linguagem, ou seja, sua função é apenas conceituar o termo "street children" para o professor que não esteja familiarizado com o mesmo.

As "notas de conteúdo" vêm para complementar o que o texto deixa a desejar a respeito da capoeira. A primeira nota diz respeito ao berimbau e ao atabaque. A nota é breve e se restringe à descrição física de ambos instrumentos. A segunda nota, traz a pronúncia "correta" da palavra capoeira com sotaque norte americano (Kah-poh-air-rah) e a define como sendo uma forma de arte afro-brasileira que combina elementos das artes marciais, música e dança.

No Brasil, a palavra capoeira possui duas variações de pronúncia: "capôeira" e "capueira", que podem ser transcritas foneticamente como /kapo'eira/ ou /kapv'eira/. Sobre as origens da capoeira, a nota diz serem incertas, mas que teria sido trazida para o Brasil por escravos africanos em meados do século dezesseis. A nota completa ainda que a capoeira era uma forma de os escravos transmitirem sua cultura e habilidades de luta quando era proibido.

A terceira e última nota explica que Salvador, São Salvador da Bahia de Todos os Santos possui um centro histórico dos séculos XVII a XIX, o que faz dela um destino turístico popular. Em contraposição a essa informação, a nota coloca que existem mais de dezesseis mil crianças pobres vivendo nas ruas de salvador. Há ainda a constatação de que existe crimes e mortes nesse meio e que a missão do Projeto Axé é ajudar essas crianças. É compreensível a limitação da unidade em 
retratar a realidade de maneira mais completa e fidedigna, em contrapartida, notas simplistas não chegam próximo de solucionar o problema.

Passo então para os exercícios da página dez, ilustrados nas figuras quinze e dezesseis. Assim como no texto sobre o carnaval, o exercício A, ilustrado na figura quinze, conta com perguntas de múltipla escolha com respostas diretas facilmente identificáveis no texto, já que não exigem interpretação. Dentre as perguntas, estão a cor das roupas usadas na capoeira e as atividades que Milton dos Santos gosta de fazer. O exercício $B$, ilustrado na figura dezesseis, por sua vez, consiste em trechos extraídos do texto para que os alunos completem as lacunas. O exercício que poderia levar o aluno a pensar um pouco mais para buscar as informações no texto, traz um quadro com as palavras a serem usadas nas lacunas. Um quadro no destaque "Você sabia?" traz Brasil, Coréia e Japão como alternativas de países de onde surgiu o Taekwondo. Nenhuma das atividades remete à preocupação social sugerida no primeiro parágrafo do texto, um fato consistente com o restante do material, onde a cultura e o social aparecem meio que para cumprir uma cota. Inúmeras seriam as possibilidades de exploração deste tópico caso o foco fosse o menino pobre que foi auxiliado pelo Projeto Axé e se descobriu na capoeira.

\section{Comprehension}

A Answer the questions about Capoeira:The Fighting Dance. Circle the correct answers.

I. Who does the Axe Project NOT help?
a. teenagers
b. poor children
c. parents

2. What does "it" mean in line 5 ?
a. the group
b. the school
c. the children

3. The people inside the circle.
a. sing
b. fight
c. play instruments

4. Capoeira fighters wear
a. karate clothes
b. sandals

5. What does Milton dos Santos like to do?
a. sing
b. dance

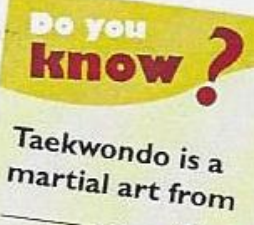

a. Brazil

b. Korea

c. Japan

Figura 15 - Compreensão de texto: capoeira.

Fonte: Collins e Maples (2010b). 
B Use the words below to complete the text.

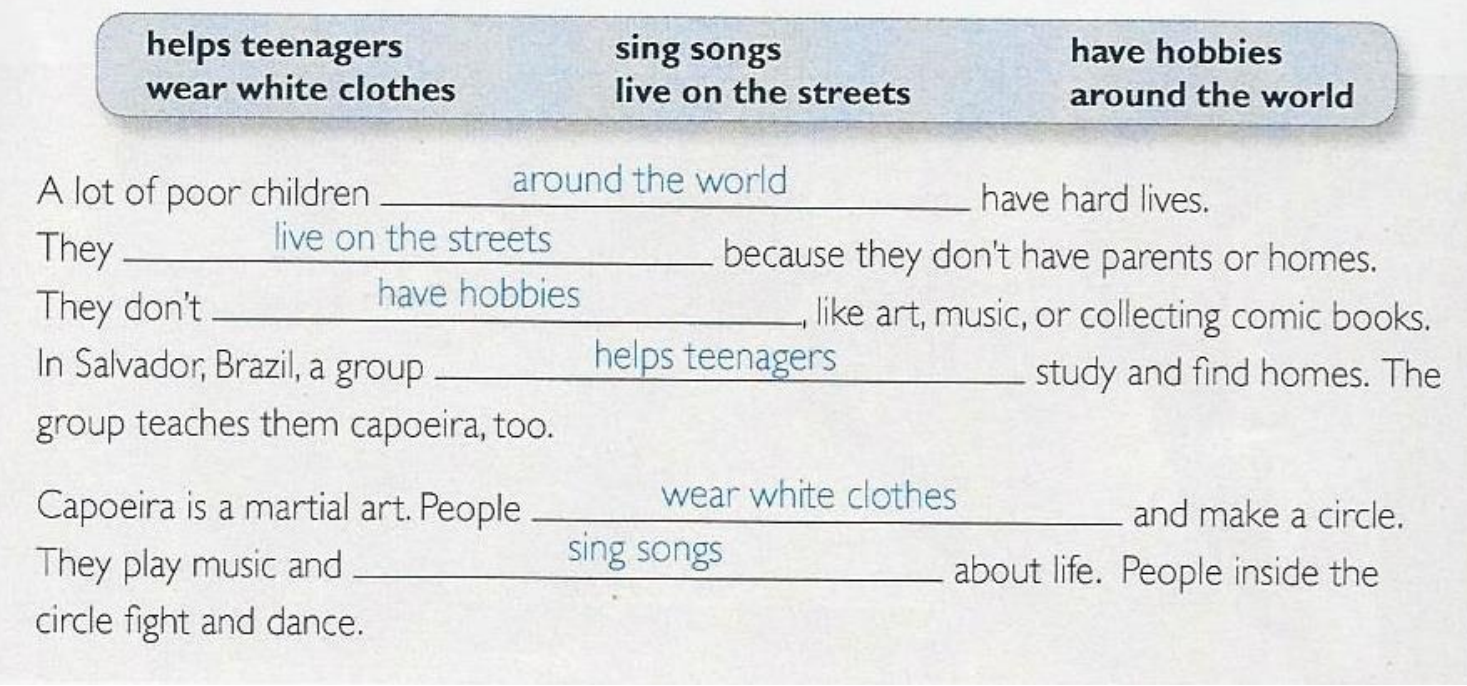

Figura 16 - Exercício: capoeira.

Fonte: Collins e Maples (2010b).

Ao final da página, o tópico de redação traz como modelo um email escrito em primeira pessoa falando sobre hobbies e atividades favoritas, lembrando-nos de que esse era o tema da lição. Já a página onze, Mundo Real, consiste em uma pesquisa sobre os esportes favoritos dos colegas. Se não vamos problematizar e discutir os problemas sociais, seria mais honesto trazer a capoeira como esporte e descartar o papel social do projeto de uma vez.

Considerando-se que o material acompanha um componente digital, uma maneira de trazer a capoeira para os alunos de outros países seria através de vídeo. Um vídeo curto enriqueceria a experiência dos alunos no tocante ao som dos instrumentos e os tipos de movimentos realizados. Uma nota descritiva para o professor não permite que os alunos vivenciem um pouco da cultura do outro. Da maneira com que foi feito, nem os alunos de outros países que usam o livro têm a chance de empatizar com o tema, nem os alunos brasileiros são levados à reflexão. Afinal, eles poderiam responder às perguntas sem ler o texto. Na ânsia de atender a todos os mercados, vale-se do tokenismo e não se atende a nenhum. Na tentativa de ser politicamente correto, usa-se a cultura e os problemas sociais como se usa uma cartola em uma noite de gala: é bonita, cumpre o protocolo, fica bem aos olhos externos, mas não cumpre função alguma. 
Passo para o segundo e último texto sobre o Brasil na coleção: "Amazônia Radical", figuras dezesseis e dezessete. A primeira atividade pede que os alunos passem os olhos pelo texto e respondam à pergunta: "Por que o Rio Amazonas é importante para o meio ambiente?", em seguida, sugere-se a leitura completa do texto para sublinhar os adjetivos e responder as perguntas da página trinta e oito. $\mathrm{A}$ nota de ensino para o professor, "teaching note", sugere que seja dado aos alunos tempo suficiente para olhar o texto todo, mas não para lê-lo cuidadosamente. O livro do professor acompanha ainda uma nota de conteúdo e uma de linguagem que discutirei mais adiante. A figura maior mostra o Rio Amazonas e um zoom no globo terrestre destaca a sua localização. Três outros destaques mostram fotos de animais: sucuri, preguiça e piranha.

O texto inicia estabelecendo o quão radical ou "extrema" a Amazônia é:

\begin{abstract}
A Amazônia é um lugar verdadeiramente extremo. Ambos o maior rio e a maior floresta tropical estão na Amazônia. O Rio Amazonas começa na Cordilheira dos Andes, no Peru, e corre por cerca de $6.000 \mathrm{~km}$ para o Oceano Atlântico. É o segundo rio mais longo do mundo. É também o rio mais largo do mundo. Durante a estação das chuvas, partes do rio aumentam para $190 \mathrm{~km}$ de largura! Vinte por cento da água doce em todos os oceanos do mundo vem do Rio Amazonas. Isso sim é extremo!
\end{abstract}

O texto é bastante preciso em retratar a Amazônia enquanto floresta e rio, mas não como região habitada. Pelo texto tem-se a impressão de ser uma área natural isolada da população, o que em si é também um esterótipo. Ao ler o texto, temos a sensação de estar lendo uma página da National Geographic ou de uma enciclopédia. Por que o mesmo não acontece quando os textos envolvem pessoas e culturas?

Talvez porque, ao nos posicionarmos a respeito do outro, sempre o fazemos a partir do nosso ponto de vista, ou seja, um ponto de vista que é, invariavelmente, marcado por nossas crenças, convicções e percepções acerca do mundo ao nosso redor. A esse respeito, Brown (2007, p. 189) diz:

O que parece ser, para você, uma percepção precisa e objetiva de um indivíduo, costume, ideia, pode ser 'distorcido' ou 'afetado' aos olhos de alguém de outra cultura. Mal-entendidos são, portanto, prováveis de acontecer entre membros de diferentes culturas. Pessoas de outras culturas podem parecer, aos seus olhos, 'barulhentas' ou 'quietas', 'conservadoras' ou 'liberais' com relação ao seu próprio ponto de vista. 
O que eu, brasileira, vejo como mal entendido de minha cultura, aos olhos dos autores, americanos, pode parecer um retrato preciso de minha cultura e de meu país. No entanto, seria simples tomar essa verdade para justificar todas as generalizações observadas até então e desconsiderar por completo a validade do presente trabalho e das discussões por ele propostas. Quando a própria coleção se propõe a: "motivar os alunos a pensar e aprender sobre problemas reais, fazendo com que os alunos falem sobre eles (em inglês) o mais cedo possível" (COLLINS; MAPLES, 2010b, p. vii) relevar a neutralização cultural praticada no material deixa de ser uma opção.

Voltando para o texto, pode-se ler:

O Rio Amazonas corre pela maior floresta tropical do mundo. Esta floresta
tropical tem o maior número de plantas e animais da terra. Há cerca de 2.5
milhões de tipos de insetos e 3 mil tipos de peixes. Um quinto de todos os
pássaros do mundo vive na Amazônia. Alguns animais na floresta tropical
são perigosos, mas outros não. Eles são animais assustadores, como a
carnívora piranha e a sucuri, uma das maiores cobras do mundo. Mas há
também animais dóceis, como a preguiça.

Um aspecto importante que não é abordado aqui é o fato de muitos destes animais estarem ameaçados de extinção, visto que um dos pilares do material é inspirar as pessoas a se preocuparem com o meio ambiente. O próprio material traz essa preocupação como sendo prioridade: "Nós acreditamos que a filosofia da National Geographic de - 'inspirar pessoas a se importarem com o planeta' deveria ressoar entre os jovens" (COLLINS; MAPLES, 2010b, p. vii). Esse compromisso, assim como o de desviar o foco das culturas ocidentais para o mundo como um todo não parece ter sido posto em prática de modo a proporcionar aos alunos uma vivência significativa do mundo. Os temas apresentados cumprem mais a função de ilustrar as unidades do que de fato promover uma visão crítica do mundo.

O último parágrafo do texto conclui o tópico dizendo: "A Amazônia é muito importante para o meio ambiente. Muitas pessoas estão tentando salvar as plantas e animais na Amazônia.". Salvar do que? Ou de quem? Essa colocação fica solta no final do texto. Quais problemas existem na Amazônia? Um local retratado com tanta grandeza no texto não parece estar ameaçado. 


\section{Reading}

A Skim the text. Then answer the question.

Why is the Amazon River important to the environment?

It collects fresh water.

Many animals and plants live there.

B Read the article. Underline the adjectives.

C Answer the questions on page 38 .

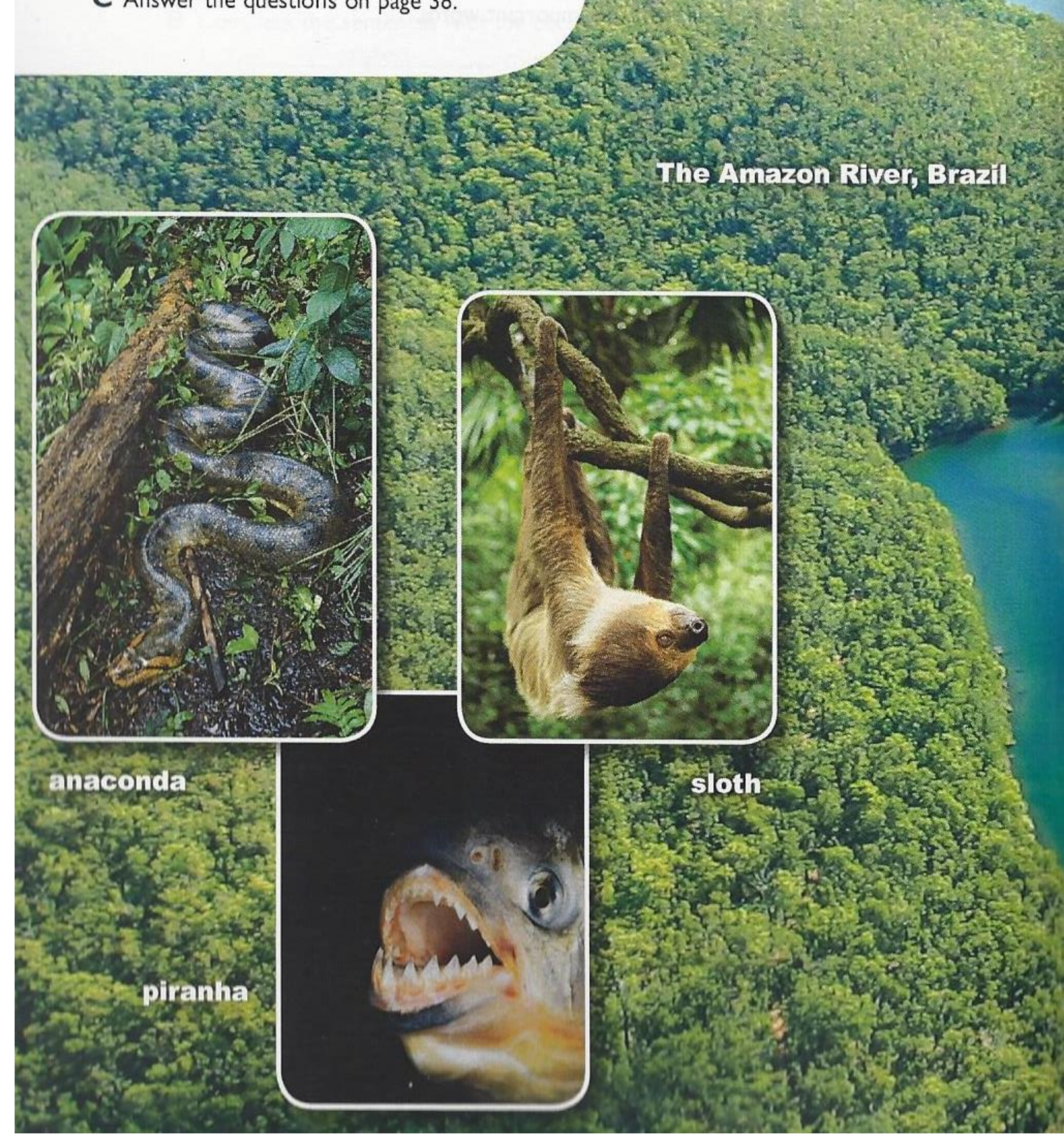

Figura 17 - llustração sobre a Amazônia.

Fonte: Collins e Maples (2010b). 


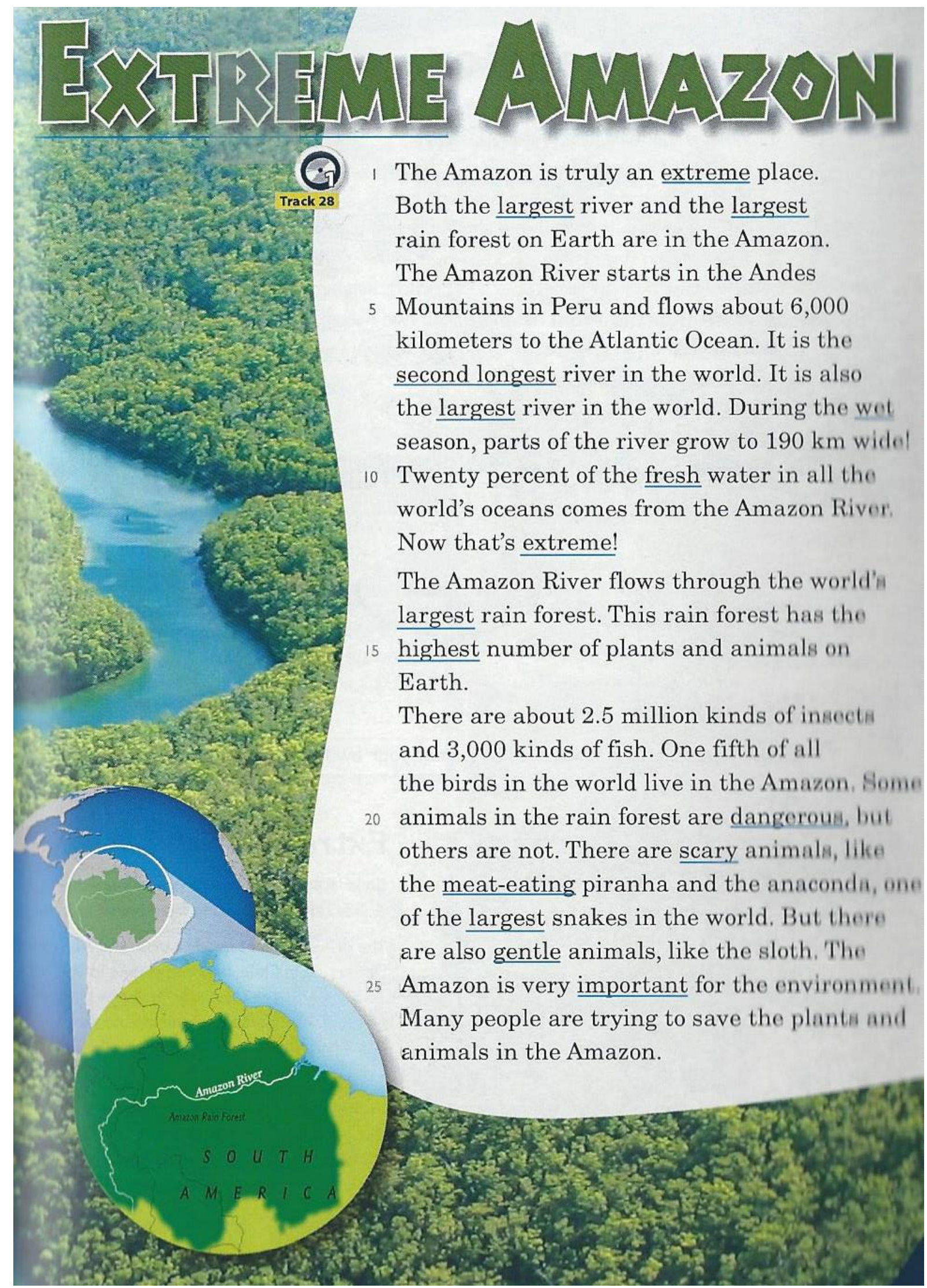

Figura 18 - Texto sobre a Amazônia.

Fonte: Collins e Maples (2010b). 
Passemos então para as notas do professor. A primeira, de conteúdo, cita que mais da metade das florestas tropicais do mundo já foram perdidas devido à demanda por madeira e por terras para as fazendas. A nota segue mencionando que o Brasil possui $30 \%$ da floresta tropical restante no mundo e que mais de 50 mil milhas quadradas foram destruídas entre 2000 e 2005. Sem a extensão total da floresta, especialmente considerando-se que vários países para os quais o livro é distribuído utilizam o sistema métrico, fica difícil mensurar a importância desta informação. A nota ainda diz que o desmatamento tem efeitos negativos no meio ambiente, visto que $70 \%$ dos animais terrestres e plantas vivem nas florestas e não poderiam sobreviver se suas casas fossem destruídas. Para finalizar, a nota termina dizendo que o desmatamento leva à mudança climática e que a redução no número de árvores pode acelerar o aquecimento global. Como se pode observar, o autor tenta resumir muitas informações em uma simples nota ao professor, fazendo com que fatos de grande relevância se tornem novamente curiosidades.

A última nota ao professor diz respeito à pronúncia da palavra piranha $(\mathrm{Pi}$ rah-nah), uma palavra utilizada na língua inglesa em filmes e desenhos animados com a pronúncia americanizada. A pronúncia da palavra piranha em português é transcrita foneticamente como /pi'rẽna/. Aqui, a sugestão de pronúncia não apresenta a mesma falha vista na pronúncia da palavra "capoeira", haja visto que a palavra "piranha" com a pronúncia sugerida está estabelecida e incorporada à língua inglesa.

Mais uma vez, a promessa de que a coleção prima por uma visão mais globalizada de mundo e menos ocidentalizada não se cumpre. As realidades e percepções expressas ao longo do material não são neutras. Wierzbicka (2003, p. 25) descreve este fenômeno na fala: "Não são as pessoas em geral que se comportam da maneira descrita, são os falantes de inglês". Fica claro no decorrer das lições que não basta escrever um livro no qual todos os personagens são estrangeiros se os diálogos e situações nas quais eles são colocados poderiam ser facilmente intercambiáveis. Ao despi-los dos traços culturais que os fazem únicos, deixamos de ter um personagem que cumpra a função de minoria para termos um livro repleto de minorias com características americanizadas.

Assim como nos outros textos, o exercício $A$, de interpretação de texto, que acompanha o texto da Amazônia é de múltipla escolha com perguntas de resposta direta. Considerando-se que toda a explicação acerca do desmatamento é trazida 
nas anotações do professor e que, podem ou não ser trazidas para a sala de aula, o texto não daria margem a perguntas que gerassem qualquer tipo de discussão mais aprofundada. $O$ exercício $B$, assim como o que acompanhava a atividade sobre os feriados no volume um, traz balões para que se crie um mapa do texto. Diferentemente do exercício do primeiro volume, este exercício não fornece o vocabulário a ser usado para completar a atividade. No quadro de destaque, pergunta-se o tamanho que uma sucuri pode chegar.

\section{Comprehension}

A Answer the questions about Extreme Amazon.

I. What is the main idea of the text?

a. A lot of interesting animals live in the rain forest.

b. The Amazon River is very large and long.

c. The Amazon is an extreme and important place.

2. The Amazon River is the river in the world.
a. longest
b. largest
c. most dangerous

3. The Amazon rain forest has more than two million kinds of
a. fish
b. birds
c. insects

4. The piranha is a kind of
a. snake
b. insect
c. fish

5. The is a gentle animal.
a. sloth
b. anaconda
c. piranha

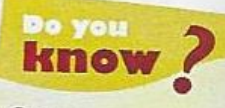

Green anacondas can grow to

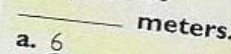

b. (9)

c. 12

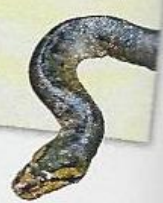

B Make a word web about the text.

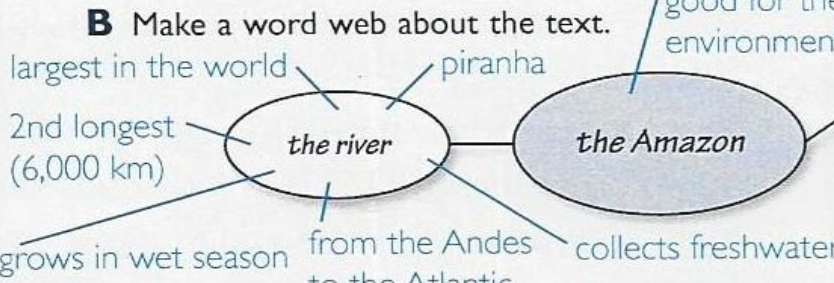

to the Atlantic

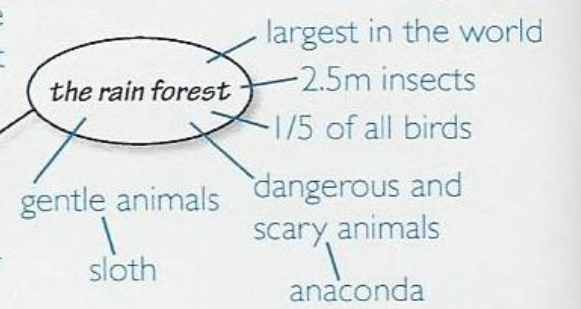

Figura 19 - Compreensão de texto: Amazônia.

Fonte: Collins e Maples (2010b).

Como nas outras lições, a última atividade após o texto consiste na produção de um pequeno parágrafo. O modelo para produção deste parágrafo é um pequeno artigo intitulado "Chile Extremo". O artigo traz informações sobre o deserto do Atacama e incentiva os alunos a produzirem um pôster com informações sobre a sua própria cidade ou país. Uma atividade que leva o aluno à produção de conteúdo a partir de seu próprio contexto cultural. Atividades assim poderiam ter sido utilizadas com maior frequência a fim de evitar a consolidação de uma visão unilateral das culturas retratadas na coleção. 
A sessão "Mundo Real", a última de cada lição, traz um quadro para que se complete o tamanho, população e número de pessoas por quilômetro quadrado em cada continente. No destaque, um balão pergunta qual é a maior cidade do mundo e traz três fotos para ilustrar a pergunta: Tóquio, Japão, a maior em população considerando-se a população das redondezas; Bombaim, Índia, a maior em população considerando-se a população que vive dentro da cidade; e Altamira, Brasil, a maior em extensão territorial. Em um quadrado no canto inferior, o autor traz a expressão idiomática "I have a mountain of work" com três alternativas de significado. Nesta página, fica difícil definir qual é a prioridade e qual das atividades é menos significativa para os alunos, visto que poucas delas incluem real produção de conteúdo. Não há ganho significativo de conteúdo, de linguagem ou de cultura com nenhuma dessas informações.

Nesse capítulo analisei os textos e diálogos nos quais a cultura Brasileira é figurada na coleção de livros didáticos de inglês para adolescentes Time Zones. Mostrei as diversas instâncias em que o autor mostrou o país, a sua cultura e o seu povo de modo reducionista, valendo-se de generalizações e estereótipos. No capítulo seguinte, farei as considerações finais acerca das análises realizadas à luz de todas as teorias que foram discutidas até o presente momento. Farei também sugestões de como se pode trazer a cultura para a sala de aula sem que ela seja neutralizada e, mais importante, de modo que o aluno possa se apropriar da cultura e fazer uso apropriado dos scripts culturais adequados a cada interação comunicativa. 


\section{CONSIDERAÇÕES FINAIS}

Ao longo da presente dissertação, defini que cultura é o conjunto das características que identificam e uma comunidade em um dado período. Mostrei também que língua e cultura são indissociáveis, haja vista que uma língua sem cultura não passa de um conjunto de regras e sons utilizados na troca de mensagens. A cultura é o que dá significado à língua e à comunicação. Isso posto, não é concebível o ensino de línguas estáticas, aculturadas, neutralizadas. É necessário que os livros didáticos de inglês como língua estrangeira EFL contemplem a diversidade em todos os seus aspectos. Se o material didático trata a cultura como coadjuvante na aprendizagem de língua, esse é exatamente o papel que ela vai desempenhar na aprendizagem e, consequentemente, na comunicação. Se oferecermos aos nossos estudantes uma cultura inexpressiva e superficial, estamos negando-lhes a oportunidade de entrar em contato com outras culturas e fazer conexões significativas.

A coleção analisada traz a promessa da diversidade cultural aliada ao conteúdo do acervo da National Geographic. Analisei os textos dos dois primeiros volumes da coleção, textos que têm o Brasil como temática. A coleção conta ainda com mais dois volumes nos quais a personagem Maya aparece em diálogos corriqueiros. Nestas aparições, sua personagem poderia ter sido facilmente substituída por qualquer dos outros personagens, ou até mesmo por uma adolescente norte-americana. Sempre que questionada a respeito de seu filme, banda ou celebridade favoritos, ela responde com uma referência norte-americana, como Shrek ou Hugh Jackman.

Retomo aqui minha primeira pergunta de pesquisa: como a cultura do adolescente brasileiro é apresentada no livro didático analisado? A personagem brasileira, Maya, assim como os outros personagens do livro, poderia ser uma adolescente americana com fisionomia latina; Stig, poderia facilmente chamar-se Matt; Ming Cheng poderia ser morador do SoHo ou de qualquer bairro nos Estados Unidos; Nadine, não possui características que a tornem mais sul-africana que os 
negros americanos. Ao comprarmos esse multiculturalismo pasteurizado e o levarmos para sala de aula sem questionamento, estamos incluindo no currículo as posições ideológicas e políticas que nos são impostas. Segundo Silva (2015, p. 16): "tudo aquilo que é deixado de fora da prática pedagógica também constitui o currículo". Ao deixarmos os problemas sociais nas notas de rodapé do livro do professor, optamos por não ver a realidade e optamos também por privar nossos alunos da mesma. Fazemos da sala de aula um desfile de finais felizes, cores vibrantes e "ricas" manifestações culturais. Passamos ao status de professores de língua e deixamos para o outro a função de educar, de formar cidadãos.

Quando iniciei essa pesquisa, a coleção Time Zones havia sido recémlançada no Brasil. Em janeiro de 2016, foi lançada a segunda edição da coleção. Sem a pretensão de reiniciar as análises e, pelo contrário, manuseei a nova edição com a esperança nutrida por todo pesquisador qualitativo, de que minha pesquisa tivesse se tornado irrelevante e de que os aspectos aqui abordados tivessem sido corrigidos. No entanto, cinco anos após a primeira edição, mesmo depois de ela ter sido usada por milhares de alunos ao redor do mundo. A segunda edição traz os mesmos diálogos com pequenas alterações no campo gráfico. O conteúdo não foi alterado, tampouco os personagens deixaram de ser adolescentes que personificam os mais diversos estereótipos.

Em uma tentativa de atender o mercado global, os livros apresentam uma cultura neutralizada que não retrata fielmente nenhum dos povos ora mencionados. A cultura desses livros é uma cultura de todos e de ninguém. Ela é neutra, não ofensiva e busca representar a todos os continentes de uma só vez e, ao fazê-lo, simplifica a riqueza e a diversidade cultural das nações. Isso posto, a produção em massa de livros didáticos que visam tão somente o lucro às custas de alunos ansioso para aprender a língua franca, somente reforça os estereótipos e aumenta a distância entre as culturas. O livro multicultural que deveria dar poder à cultura particular de cada indivíduo tornou-se um desfile de estereótipos e um amálgama de velhos clichês.

A preocupação em fazer da sala de aula de inglês um ambiente pensante, foi o cerne do trabalho de Solange Ribeiro quando, em 1971, publicou o livro chamado $A$ Tour of Brazil. No entanto, o livro não gozou do mesmo sucesso que suas outras publicações por uma série de razões descritas por Paiva (In: DINIZ; VILELA, 2009), tais como: a baixa estima do brasileiro, o encantamento pelas 
cidades europeias e a insegurança dos professores diante do caráter inovador do material. Quase meio século depois da publicação do livro de Solange, me vejo debatendo as mesmas questões e encontro ainda as mesmas reações de meus colegas quando descrevo o tema de minha pesquisa. Recebi vários olhares estranhos quando me pus a questionar o anglocentrismo presente nos livros didáticos, pois está fossilizada a ideia de que a língua inglesa deve vir acompanhada da cultura inglesa, e por cultura inglesa, obviamente, não se referem à cultura da África do Sul ou da Austrália.

A resistência à mudança atravanca o progresso da educação e, portanto, aqui estou argumentando a favor de um tema que deveria ser lugar comum nas salas de aula. Cultura é a alma de um povo. Ou como disse Brown (2007, p. 188), "cultura é um modo de vida. É o contexto no qual nós existimos, pensamos, sentimos e nos relacionamos com os outros. É a 'cola' que une um grupo de pessoas". Retomo aqui então, minha segunda pergunta de pesquisa: de que forma as representações culturais trazidas pelo livro didático de língua inglesa podem impactar a sala de aula? Não podemos reduzir o estudo da cultura às representações públicas deste modo de vida, em outras palavras, não podemos reduzi-lo a feriados, celebrações, culinárias 'exóticas' e curiosidades. A fim de compreendermos, respeitarmos e discutirmos os aspectos que levaram um grupo de pessoas a agir da maneira que age, devemos nos imergir na cultura do outro de modo a promover interação significativa $e$, consequentemente, comunicação significativa. A maneira na qual nos comunicamos e produzimos significados está fortemente arraigada em nossa cultura. Língua e cultura são, em todos os seus aspectos, inseparáveis.

Nos dias atuais, não se pode conceber qualquer tentativa de se separar língua e cultura. Estudar uma língua estrangeira foi, por muito tempo, o estudo da "língua do outro" e da "cultura do outro". No entanto, à medida que a abordagem comunicativa entrou no cenário do ensino /aprendizagem de língua inglesa, ela trouxe a ideia de que adquirir uma língua estrangeira significa tomar essa língua para si e usá-la em contextos onde haja comunicação significativa. De acordo com Almeida Filho (2011), as chances de se adquirir uma língua aumentam à medida que o aprendente interage para se comunicar na língua, o que faz dela viva e cultural. Sob essa nova perspectiva, nós vemos a cultura como protagonista no processo de ensino/apendizagem de línguas, já que se entende que a língua é cheia de cultura e 
que língua e cultura podem ocupar o mesmo espaço quando essa língua é apresentada como ação social propositada.

Nas palavras de Brown (2007, p. 194): "[...] a cultura é uma parte integrante de cada fibra de nosso ser, mas a língua - o meio de comunicação entre membros de uma cultura - é a expressão mais visível e disponível daquela cultura". Em suma, é o dever dos linguistas aplicados, professores, pesquisadores e produtores de materiais didáticos garantir que as culturas do mundo tenham a devida importância na sala de aula de língua estrangeira e precisamos usar os resultados da pesquisa em linguística para garantir que nossos alunos obtenham melhores resultados, haja visto que "[...] trabalhar com línguas é necessariamente intervir na realidade da qual ela faz parte" (RAJAGOPALAN, 2003, p. 126).

A intervenção deve fazer parte da prática diária do professor. Enquanto existirem professores, um livro didático não pode ser tomado como verdade única e absoluta. As interações de sala de aula podem ser mediadas por um livro didático, mas não podem ser ditadas por ele. A problematização do conteúdo dos livros pode e deve ser feita em aula com a participação dos alunos, caso contrário, estaremos passiva e silenciosamente contribuindo para a prosperidade dos mercados editoriais inglês e norte-americano. Nos tornamos presas fáceis.

Inglês é hoje língua franca, temos no inglês o que profetizava fazer o esperanto. Inglês é a língua da ciência, dos negócios, dos acordos de paz ou guerra, e até mesmo do lazer. O movimento de expansão da língua inglesa não pode ser detido e, sinceramente, não sei se deveria. Por outro lado, muito pode ser feito enquanto professores para que nossos alunos não sejam programados para serem os porta vozes de um discurso que foi pensado por eles. Ainda que o discurso não mude, toda pessoa que tem acesso à educação deve ter o privilégio de ser livre para pensar e produzir seus próprios discursos.

Há dezessete anos atrás tornei-me educadora. Acredito que a educação seja o único instrumento capaz de libertar o homem, pois a educação lhe dá o poder de escolher ser o que quiser ser. Muitas vezes questionei a opção de trabalhar em instituições de elite e de ter me acovardado diante dos desafios de levar educação àqueles que mais precisam, àqueles que pagam caro ao optar por frequentar a escola ao invés de trabalhar para ajudar no sustento da família. Hoje, vejo minha escolha por um ângulo diferente. As diferenças existirão sempre e a pirâmide social não é uma realidade exclusivamente brasileira. A meu ver, o trabalho na base e o 
trabalho no topo da pirâmide são igualmente importantes, pois, ao mudar a visão de mundo dos que têm acesso privilegiado às posições de poder, contribuo para que suas decisões tragam melhores condições da vida aos que estão na base da pirâmide de modo que eles possam buscar os meios necessários para lutar pela sua liberdade. 


\section{REFERÊNCIAS}

ALMEIDA FILHO, J. C. P. Dimensões comunicativas no ensino de línguas. 7. ed. Campinas, SP: Pontes, 2013.

Fundamentos de abordagem e formação no ensino de PLE e de outras línguas. Campinas, SP: Pontes, 2011.

. Quatro estações no ensino de línguas. Campinas, SP: Pontes, 2012.

ARAÚJO, J.; LEFFA, V. J. (Orgs.). Redes sociais e ensino de línguas: o que temos de aprender? São Paulo: Parábola Editorial, 2016.

BALADELI, A. P. Questões de identidade em sala de aula: que sentidos de brasilidade apresentam os livros didáticos? In: FERREIRA, A. (Org.). As políticas do livro didático e identidades sociais de raça, gênero, sexualidade e classe em livros didáticos. Campinas, SP: Pontes, 2014.

BRASIL. Lei n. 8.069, de 13 de julho de 1990. Dispõe sobre o Estatuto da Criança e do Adolescente e dá outras providências. Brasília, 1990. Disponível em: <http://www.planalto.gov.br/ccivil_03/leis/L8069.htm>. Acesso em: 11 fev. 2016.

BROWN, D. H. Principles of language learning and teaching. 5. ed. White Plains: Pearson Longman, 2007.

CAJUEIRO, R. Manual para elaboração de trabalhos acadêmicos: guia prático do estudante. Petrópolis, RJ: Vozes, 2012.

CAMBRIDGE ENGLISH. About the Common European Framework of Reference for Languages (CEFR). 2015. Disponível em: <http://www.cambridgeenglish.org/cefr/>. Acesso em: 11 fev. 2016.

CHIZZOTTI, A. A pesquisa qualitativa em ciências humanas e sociais.

Petrópolis, RJ: Vozes, 2006. 
COLLINS, T.; MAPLES, M. J. Time zones: student book 1. Boston: Heinle, Cengage Learning, 2010a.

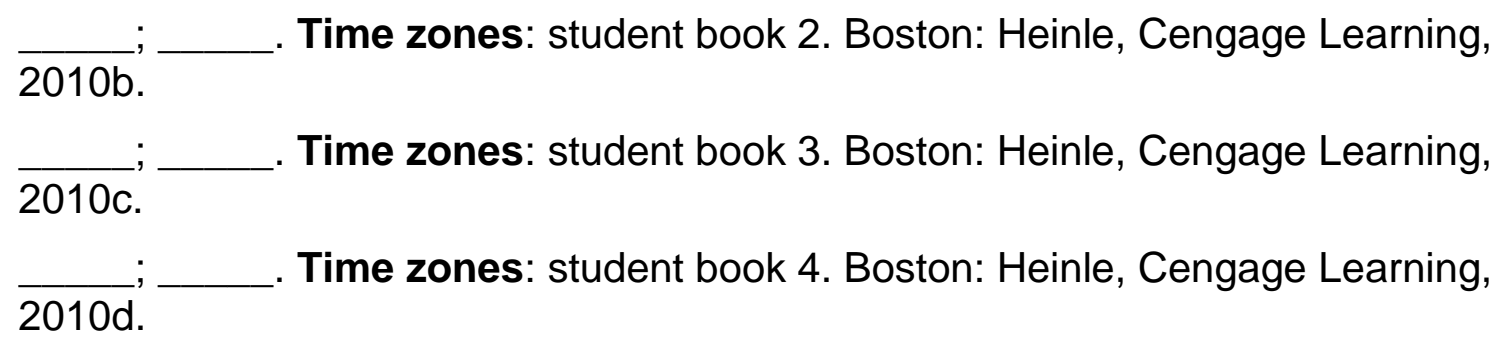

COUTINHO, L. G. A adolescência na contemporaneidade: ideal cultural ou sintoma social. Pulsional: Revista de Psicanálise, São Paulo, a. XVII, n. 181, p. 13-19, mar. 2005. Disponível em: <http://bases.bireme.br/cgi-

bin/wxislind.exe/iah/online/?IsisScript=iah/iah.xis\&src=google\&base=ADOLEC\&lang= p\&nextAction=Ink\&exprSearch=477071\&indexSearch=ID>. Acesso em: 11 fev. 2016.

CRYSTAL, D. English as a global language. Cambridge: Cambridge University Press, 1997.

DENZIN, N. K.; LINCOLN, Y. S. Introdução: a disciplina e a prática da pesquisa qualitativa. In: (Orgs.). O planejamento da pesquisa qualitativa: teorias e abordagens. Porto Alegre: Artmed, 2006.

DURKHEIM, E. Da divisão do trabalho social. São Paulo: Martins Fontes, 2010. . Sociologia e Filosofia. São Paulo: Ícone, 1994.

FÉLIX, J. The our world series. Brasília, Casa Thomas Jefferson, 5 fev. 2014. Workshop ministrado aos professores da Casa Thomas Jefferson.

FERNÁNDEZ, G. Língua e cultura: integração na aula de língua estrangeira. Revista Horizontes de linguística aplicada, Brasília, a. 1, v. 1, p. 39-44, 2002.

FREEBODY, P. Qualitaty research in education: interaction and practice. London: Sage, 2003.

GIL, A. C. Como elaborar projetos de pesquisa. 4. ed. São Paulo: Atlas, 2002.

GODDARD, G.; WIERZBICKA, A. Cultural scripts: what are they and what are they good for? Intercultural Pragmatics, Berlim, v. 1, n. 2, 153-166, 2004. 
HALL, E. Beyond Culture. New York: Doubleday, 1976.

HALL, S. A identidade cultural na pós modernidade. Rio de Janeiro: DP\&A, 2003.

HARKOT-DE-LA-TAILLE, E. Ação moral e estereótipos culturais. In: ARANTES, V. (Org.). Afetividade na escola: alternativas teóricas e práticas. São Paulo: Summus, 2003.

JOHNSON, K. E. Understanding communication in second language

classrooms. Cambridge: Cambridge University Press, 1995.

JUCÁ, R. W. Q. A língua inglesa no ensino secundário brasileiro: 1838-1930.

2010. 140 f. Dissertação (Mestrado em Educação) - Universidade Tuiuti do Paraná, Curitiba, 2010.

KAWACHI, G.; LIMA, A. P. Aspectos culturais e formação cidadã em um livro didático de inglês para crianças. In: ROCHA, C.; MACIEL, R. (Orgs.). Língua estrangeira e formação cidadã: por entre discursos e práticas. Campinas, SP: Pontes, 2013.

KOUTZII, F. A Guerra do Golfo e suas consequências na América Latina. Porto Alegre, UFRGS, 13 mar. 1991. Palestra ministrada aos professores, alunos e funcionários da FABICO.

KRAMISH, C. Language and culture. Oxford: Oxford University Press, 1998.

KRASHEN, S. Principles and practice inn second language acquisition. Oxford: Pergamon Press, 1982.

LEFFA, V. J. 0 ensino de línguas estrangeiras no contexto nacional. Contexturas, APLIESP, n. 4, p. 13-24, 1999.

LEWIS, M. et al. (Eds.) Enthnologue: languages of the world. 18. ed. Dallas: Sil International, 2015. Disponível em: <http;//www.ethnologue.com/language/eng>. Acesso em: 11 fev. 2016.

LIGHTBOWN, P.; SPADA, N. How languages are learned. 4. ed. Oxford: Oxford University Press, 2013. 
MENDES, E. Por que ensinar língua como cultura? In: SANTOS, P.; ALVAREZ, M. L. (Orgs.). Língua e cultura no contexto de português língua estrangeira.

Campinas, SP: Pontes, 2010.

MOITA LOPES, L. P. Pesquisa interpretativista em Linguística Aplicada: a linguagem como condição e solução. Delta, São Paulo, v. 10, n. 2, p. 329-383, 1994.

MORAN, P. R. Teaching culture: perspectives in practice. Boston: Heinle, Cengage Learning, 2001.

NOGUEIRA, M. C. B; Ouvindo a voz do (pré) adolescente brasileiro da geração digital sobre o livro didático de inglês. 2007. 182 f. Dissertação (Mestrado em Letras) - Pontifícia Universidade Católica do Rio de Janeiro, Rio de Janeiro, 2007.

NORTON, B.; TOOHEY, K. Identity, language learning, and social change. [S. I.]: Cambridge University Press, 2011.

NUNAN, D. Second language teaching and learning. Boston: Newbury House Teacher Development, 1999.

PAIVA, V. L. M. O. Ensino de língua inglesa: antecipando uma pedagogia pósmoderna. In: DINIZ, T. F. N.; VILELA, L. H. A. (Orgs.) Itinerários: homenagem a Solange Ribeiro de Oliveira. Belo Horizonte: Ed. UFMG, 2009.

PENNYCOOK, A. English in the world/ the world in English. In: BURNS, A.; COFFIN, C. (Eds.). Analysing English in a global context: a reader. New York: Routledge, 2007.

PEREIRA, A. L; GOTTHEIM, L. (Orgs.). Materiais didáticos para o ensino de língua estrangeira: processos de criação e contextos de uso. Campinas, SP: Mercado das Letras, 2013.

PHILLIPSON, R. Linguistic imperialism. Oxford: Oxford University Press, 1992.

RAJAGOPALAN, K. Por uma linguística crítica: linguagem, identidade e a questão ética. São Paulo: Parábola Editorial, 2003.

ROJO, R. Materiais didáticos no ensino de línguas. In: MOITA LOPES, L.P. (Org.). Linguística aplicada na modernidade recente: festschrift para Antonieta Celani. São Paulo: Parábola, 2013. 
SILVA, T. T.; HALL, S.; WOODWARD, K. (Orgs.). Identidade e diferença: uma introdução teórica e conceitual. Petrópolis, SP: Vozes, 2000.

SIMMEL, G. The sociology of Georg Simmel. Trad. de K. H. Wolff New York: The Free Press, 1950.

STAKE, R. E. Case studies. In: DENZIN, N. K.; LINCOLN, Y. S. (Eds). Handbook of qualitative research. London: Sage, 1994.

STERNFELD, L. Materiais didáticos para o ensino de português como língua estrangeira. In: ALMEIDA FILHO, J. C. P. (Org.). Parâmetros atuais para o ensino de português língua estrangeira. 2. ed. Campinas, SP: Pontes, 2009.

TOMLINSON, B.; MASUHARA, H. Materials development for language learning: principles of cultural and critical awareness. In: PEREIRA, A. L; GOTTHEIM, L. (Orgs.). Materiais didáticos para o ensino de língua estrangeira: processos de criação e contextos de uso. Campinas, SP: Mercado das Letras, 2013.

ZACHARIAS, N. T. Acknowledging learner multiple identities in the EFL classroom. [S. I.]: [s. n.], 2010. Disponivel em:

<http://puslit2.petra.ac.id/ejournal/index.php/ing/article/viewFile/18022/17932>. Acesso em: 12 out. 2011.

WIERZBICKA, A. Cross-cultural pragmatics: the semantics of human interaction. 2. ed. De Gruyter Mouton, 2003. 